\title{
Nordic Best Practices
}

Relevant for UNEP 10YFP on Sustainable Tourism and Consumer Information

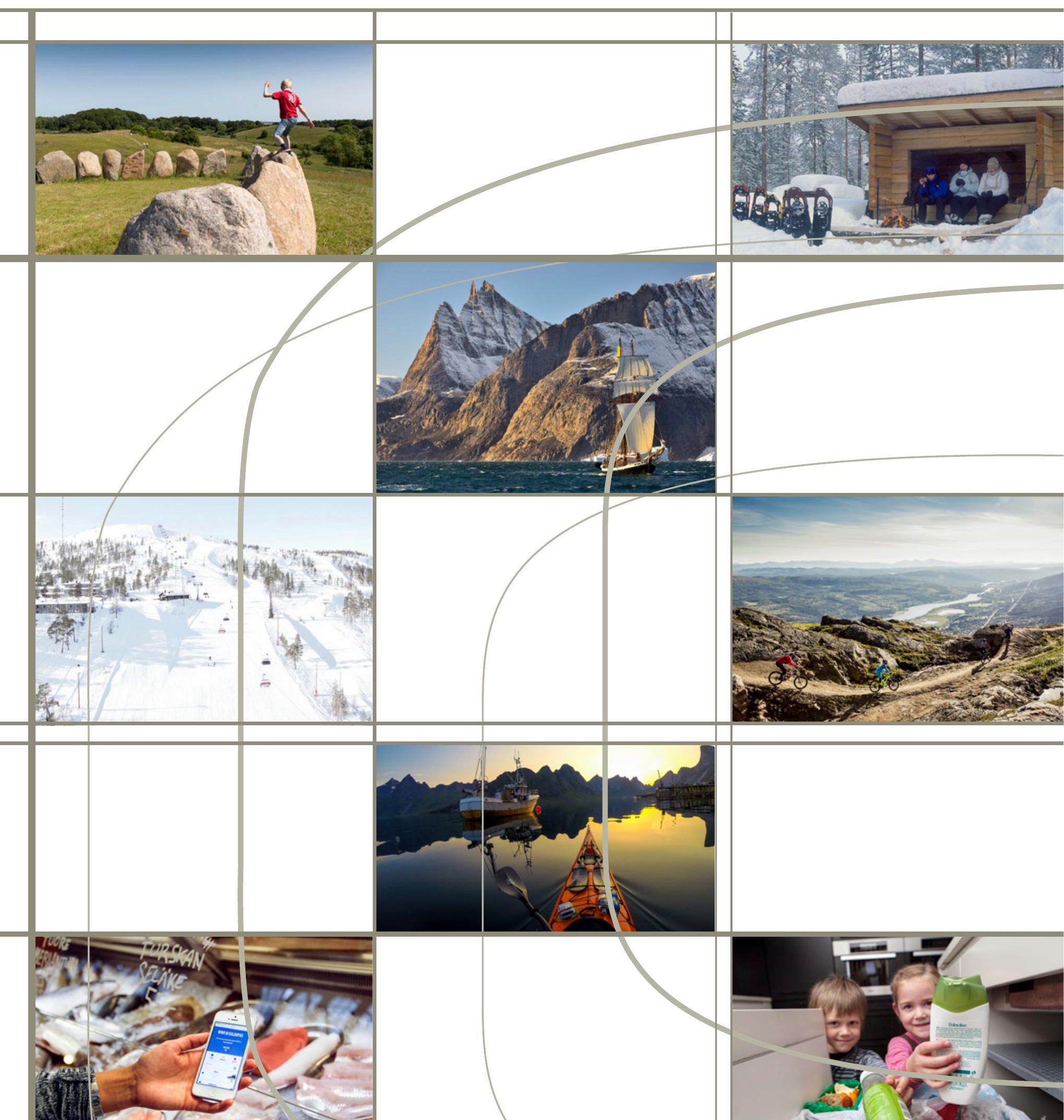







\section{Nordic Best Practices}

Relevant for UNEP 10YFP on

Sustainable Tourism and Consumer Information

Anna Hillgrén, Marika Bröckl, Laura Descombes,

Venla Kontiokari and Mikko Halonen

TemaNord 2016:546 


\section{Nordic Best Practices}

Relevant for UNEP 10YFP on Sustainable Tourism and Consumer Information

Anna Hillgrén, Marika Bröckl, Laura Descombes, Venla Kontiokari and Mikko Halonen

ISBN 978-92-893-4723-5 (PRINT)

ISBN 978-92-893-4724-2 (PDF)

ISBN 978-92-893-4725-9 (EPUB)

http://dx.doi.org/10.6027/TN2016-546

TemaNord 2016:546

ISSN 0908-6692

CC Nordic Council of Ministers 2016

Layout: Hanne Lebech

Cover photos: Ole Malling; Pyhätunturi Ltd; Tapani Vartiainen; Örvar Atli Porgeirsson;

Tomasz Furmanek; Jonas Kullman; Joonas Fritze; Johnny Syversen

Print: Rosendahls-Schultz Grafisk

Printed in Denmark

This publication has been published with financial support by the Nordic Council of Ministers However, the contents of this publication do not necessarily reflect the views, policies or recommendations of the Nordic Council of Ministers.

\section{www.norden.org/nordpub}

\section{Nordic co-operation}

Nordic co-operation is one of the world's most extensive forms of regional collaboration, involving Denmark, Finland, Iceland, Norway, Sweden, and the Faroe Islands, Greenland, and Åland.

Nordic co-operation has firm traditions in politics, the economy, and culture. It plays an important role in European and international collaboration, and aims at creating a strong Nordic community in a strong Europe.

Nordic co-operation seeks to safeguard Nordic and regional interests and principles in the global community. Common Nordic values help the region solidify its position as one of the world's most innovative and competitive.

\section{Nordic Council of Ministers}

Ved Stranden 18

DK-1061 Copenhagen K

Phone (+45) 33960200

\section{www.norden.org}




\section{Contents}



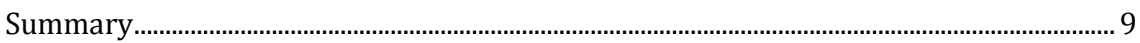

Sustainable Tourism ...............................................................................................................1

1. Denmark ......................................................................................................................................13

1.1 Green Solution House .........................................................................................13

1.2 The Green Group in Roskilde University Center Tourism Network..............20

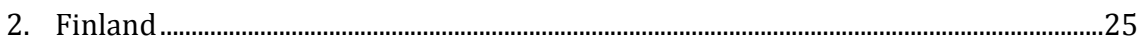

2.1 Pyhätunturi - First carbon neutral resort in Nordic countries.......................25

2.2 Metsähallitus Parks \& Wildlife Finland - Sustainable nature tourism........30

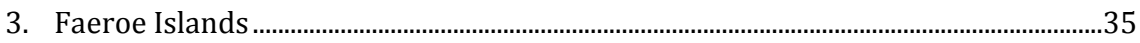

3.1 Lakeside Excursions...............................................................................................35

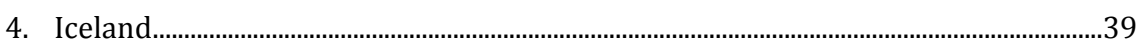

4.1 North Sailing - Sustainable Whale Watching.......................................................39

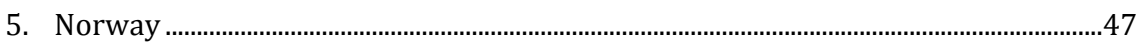

5.1 Destination Røros - award winning Sustainable Destination .........................47

5.2 Lofoten Kajakk - certified ecotourism activities..................................................53

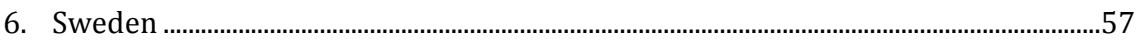

6.1 Wild Sweden ..............................................................................................................5

6.2 Sustainable Destination Development...............................................................62

Consumer Information ........................................................................................................73

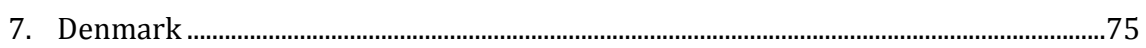

7.1 Pregnant? Know your chemicals.........................................................................75

7.2 The Organic Cuisine label......................................................................................

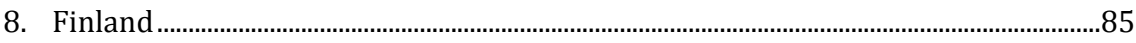

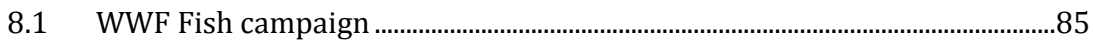

8.2 Harvest season calendar ......................................................................................91

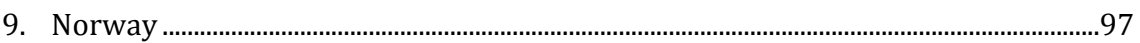

9.1 Matvett - information concept for food waste reduction towards

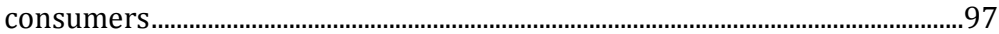

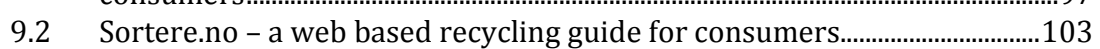

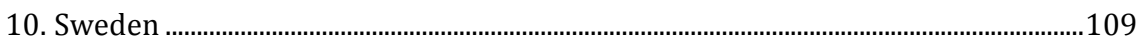

10.1 Hello Consumer - Hallå konsument by the Swedish Consumer Agency.109

10.2 Green Guide App by Swedish Society for Nature Conservation ...................114

11. Regional............................................................................................................................119

11.1 The Nordic Ecolabel - The Swan.......................................................................119

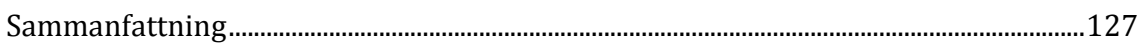

SCP Themes and Sectors in UNEP's SCP Clearinghouse ...................................................129

SCP Communities in UNEP's SCP Clearinghouse...............................................................131

Types of Initiative in UNEP's SCP Clearinghouse...............................................................133 



\section{Preface}

The 2030 Agenda outlines an ambitious and universal plan of action for people, planet and prosperity as it seeks to strengthen universal peace and freedom more broadly. While it sets an inspirational and targeted framework for eradicating poverty in all its forms and dimensions, it also outlines a way to shift the world onto a more sustainable and resilient path.

The Nordic countries, including autonomous regions, have a long tradition in advancing the goals of sustainable development at national level as well as internationally - including the launch of United Nations Environment Programme (UNEP) in Stockholm 1972, the formulation and launch of the already "classic" definition of sustainable development in the "Brundtland report" and with important Nordic input to the Rio summit in 1992, to the establishment of the MDGs in 2000, the launch of the first Nordic Strategy on Sustainable Development in 2001, and eventually to the adoption of the Sustainable Development Goals (SDGs) in 2015.

UNEPs 10 Year Framework Program (10YFP) for Sustainable Consumption and Production (SCP) is a concrete result of the Rio process, in particular the Rio+20 (2012). The purpose of the framework is to enhance international cooperation to accelerate a shift towards sustainable consumption and production (SCP) in developed and developing countries.

The 10 YFP will develop, replicate and scale-up SCP and resourceefficiency initiatives in order to decouple environmental degradation and resource use from economic growth, and thus increase the net contribution of economic activities to poverty eradication and social development. This work is also important related to green economy.

The Nordic working group on Sustainable Consumption and Production (HKP gruppen), under the Nordic Council of Ministers, launched this project for identifying, writing out and publishing best practice cases of sustainable consumption and production from Nordic countries - to be shared within the Nordic region, but even more so to be shared internationally within the UNEP SCP Clearinghouse. After a tender call Gaia Consulting Ltd was awarded to conduct this assignment with a focus on Sustainable Tourism and Consumer Information. A previous project identified Nordic best practice examples of sustainable lifestyles and education, and 
sustainable public procurement (see Nordic best practices relevant for UNEP 10YFP of sustainable consumption and production ${ }^{1}$ ).

This project identifies and showcases ten Nordic best practice examples of Sustainable Tourism, including Ecotourism and nine Nordic best practice examples of Consumer Information. The cases are presented in this final report. They have also been published at the UNEP SCP Clearinghouse ${ }^{2}$ to allow for wide international distribution and sharing of lessons learned.

The Gaia project team included Anna Hillgrén (as project manager), Marika Bröckl, Laura Descombes, Venla Kontiokari and Mikko Halonen (as project director). The work was supervised by a steering group consisting of the following Nordic focal points to the UNEP 10 Year Framework Program (lOYFP): Helene Hoggen, the Norwegian Ministry of Climate and Environment; Eva Ahlner/Annica Carlsson, the Swedish Environmental Protection Agency; Taina Nikula, the Finnish Ministry of the Environment; Birgitte Jørgensen Kjær, the Danish Environmental Protection Agency; and Sigurbjorg Saemundsdottir, the Icelandic Ministry for the Environment and Natural Resources.

The HKP group hereby wants to express its gratitude to Gaia team for thorough and flexible collaboration as well as to the steering group for their contribution to the project and hopes the results will be of inspiration for many others.

Helsinki 24th August 2016, on behalf of the NCM SCP working group ("HKP gruppen").

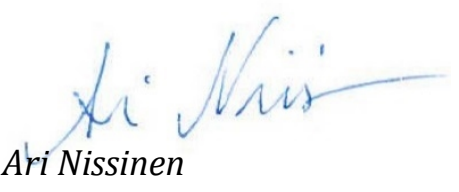

Chair of the SCP/HKP group,

Head of Unit Environmental Efficiency,

Finnish Environment lnstitute

${ }^{1}$ http://norden.diva-portal.org/smash/get/diva2:905930/FULLTEXT02.pdf

2 http://www.scpclearinghouse.org/scp - initiatives.html 


\section{Summary}

The Nordic countries have a long tradition in advancing the goals of sustainable development. The Nordic countries have actively and successfully worked on various national and international fora to prevent resource scarcity and unsustainable exploitation of natural resources. Also, the Nordic countries have been able to identify and put into practice a number of innovative partnerships that harness the expertise and business potential of the private sector actors for a shift toward more sustainable consumption and production patterns.

This report is the second report in TemaNord series showcasing Nordic experiences in promoting sustainable consumption and production (SCP). The goal is to share Nordic Best Practices and lessons learned with other stakeholders and partners in Nordic countries and internationally.

This report presents nineteen initiatives that cover two particular themes: 1) Sustainable Tourism, including ecotourism, and 2) Sustainable Consumer Information. The cases were identified together with the Nordic Council of Ministers working group on SCP. The chosen initiatives were selected from a wide variety of Nordic cases. The target was that the cases facilitate the spreading of knowledge on effective, successful and sustainable means of advancing SCP. The cases are presented in a manner designed to facilitate a comparison of strengths, key results, novelty and lessons learned of each particular case. They have been compiled and presented in a comparative and comprehensive manner in order to facilitate uptake and replication of best practices. The case descriptions are based on material made available to the consultant, including documents shared by the case representatives as well as information gathered through case interviews. Validation of the completeness and/or accuracy of data provided has not been part of the assignment.

The ten cases in the theme Sustainable Tourism consist of different projects and programs designed to guide people towards a more sustainable tourism, as well as sustainable destinations. The case target groups range from average tourist to enthusiastic ecotourists as well as tourism operators and destination developers. 
The Sustainable Consumer Information theme consists of nine cases, where the focus is on supporting consumers' sustainable choices by offering means to more easily access reliable information about sustainability aspects. The cases include ecolabels, information campaigns, websites, mobile applications as well as a cooperation model for authorities.

In line with the overall objectives of this Nordic project on best practices, the cases have also been added into the UNEP's 10 Year Framework Program (10YFP) information platform, the SCP Clearinghouse. ${ }^{3}$ The SCP Clearinghouse is a web-based information sharing tool, which can be used by different actors as an inspiration for advancing SCP worldwide. The SCP Clearinghouse also provides additional information and links for further information on the cases presented in this report.

3 http://www.scpclearinghouse.org/ 
Sustainable Tourism 



\section{Denmark}

\subsection{Green Solution House}

\section{Figure 1: Green Solution House and its surroundings}

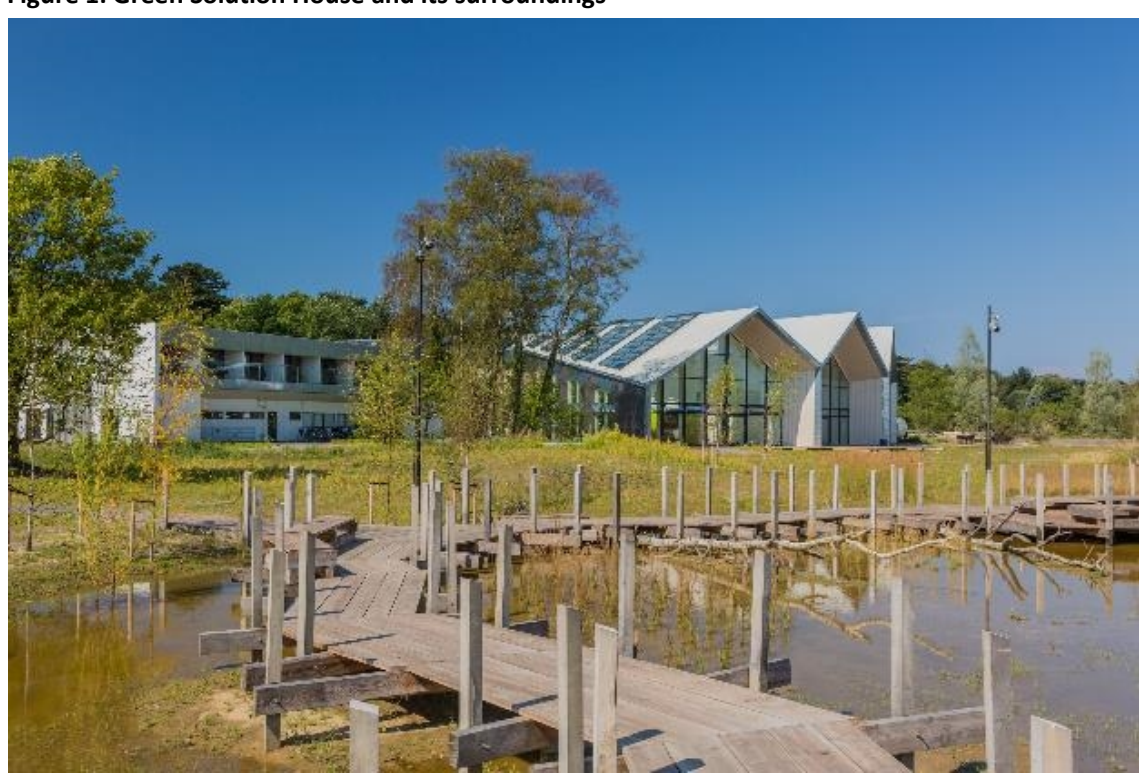

Source: Justine Høgh/Green Solution House.

$\begin{array}{ll}\text { Case Description } & \\ \text { Country: } & \text { Denmark (Region: Europe) } \\ \text { Geographic scope: } & \text { Local } \\ \text { Theme: } & \begin{array}{l}\text { Tourism, Lifecycle Perspective, Buildings } \\ \text { and Construction, Waste, Energy, Water }\end{array} \\ & \text { Sustainable Buildings and Construction, } \\ \text { Community: } & \text { Energy Efficiency, Sustainable Tourism } \\ \text { Type of Initiative: } & \text { Information, awareness-raising, education } \\ \text { Lead actor: } & \text { Carl Edvard Mogensens Foundation } \\ \text { Type of lead organization: } & \text { Foundation }\end{array}$




\section{Budget}

Ca. EUR 11.4 million. Green Solution House has been made possible by the generous support of both local, national and international foundations.

\section{Partners}

Green Solution House has been realised by a team of advisors who worked in close collaboration, bringing their own expertise to push forward innovative solutions. The advisors are 3XN architects (conceptual design), Steenbergs Tegnestue (architectural detailing), SLA (landscape design), Ramboll (engineering), COWI (client advisor) and GXN innovation (consultant on sustainability).

The strategic partners are the key players in the co-creation approach of the Green Solution House and implementation of the green solutions. The strategic partners are Realdania, VELUX Group, Autodesk Research, GXN Innovation and Saint-Gobain's Danish companies.

In addition, a number of other partners with particular expertise have contributed, such as local glass artist Pernille Bülow, Bornholms Mørtelværk, and NCC Bornholm.

Status

Renovation was started in 2007 and completed 2015. Operation was started in 2015 and is ongoing.

\section{Next steps}

Green Solution House will work with Oxford University on research related to the connection between daylight and better sleep and health. The research project starts with building a small glasshouse in the beginning of April 2016. Guests wishing to reside in the glasshouse and take part in the research will have their sleep measured. In a year, the glasshouse will be disassembled and the research repeated at other locations in different climate zones.

Green Solution House will also work with the Danish Alexandra Institute. In this project, guests will be asked about their behaviour from the sustainability point of view, and whether Green solution House will have an impact on their behaviour. The goal is to see, how guests can be impacted and what are good means to achieve it. The results from Green Solution House will be compared with another Danish hotel chain, where different methods to inform the guests about sustainability are used. The research will begin in May 2016 and run for at least a year.

Contact person for more information:

Trine Richter, tr@greensolutionhouse.dk

Note: Case descriptions, e.g. with regards to geographic scope, theme, community, type of initiative, and type of lead organisation, follow the groupings used within UNEP's SCP Clearinghouse. 


\subsubsection{Introduction}

Green Solution House, a hotel and conference centre on Bornholm, Denmark takes sustainability to a new level. The building, landscape and operation show a holistic approach to sustainable design, emphasising regenerative solutions including healthy indoor climate, renewable energy sources, active materials and recyclability. All materials used in the building are either fully recyclable or biodegradable. Hence, the building design takes on the ambition to eliminate the concept of waste. The design and development of the conference centre are inspired by the principles of Cradle-to-Cradle, the vision of Active House and the standards of the recognised German Sustainable Building Council (DGNB). Green Solution House aims to inspire its visitors and facilitate understanding of sustainability issues. Green Solution House exchanges knowledge about sustainable solutions locally and globally, and works together with universities and other partners in order to benefit other projects.

\subsubsection{Objectives}

Green Solution House aims to be more than just a hotel. The mission of Green Solution House is to explore sustainable circular economy and inspire its visitors by offering a comfortable stay in a healthy and creative environment. The plan is to try out, demonstrate and continuously revisit the green solutions, as the founders believe that iteration creates understanding and leads to innovation. One goal is to exchange knowledge with the local and global communities in order to inspire creating a sustainable future. Green Solution House, together with its strategic partners, display the "Green Solution House" case across the globe in seminars and events about sustainability and innovative materials. Green Solution House works together with other partners, such as universities, in order to share knowledge and thus benefit other projects locally, nationally and globally.

\subsubsection{Activities}

The hotel itself dates back to the 1960's, but the Green Solution House story begins in 2007, when a workshop seeking solutions to growth was held on the island of Bornholm. Tourism is a major source of income on Bornholm, and conferences were seen to be the means with which to extend the season beyond summer tourism. Sustainability was chosen as a means of growth, in order to create not just one conference centre among others. Since then, the hotel has undergone major renovation. 
In 2008, a first market analysis was undertaken, with the aim of also ensuring economic sustainability. In the following three years the concept was further developed. The key decision related to how to make the conference centre sustainable. The Cradle-to-Cradle concept was chosen as the main principle. The Active House vision aims at creating a healthy indoor climate, utilising daylight, and using energy in a smart way. The renovation was designed so it would qualify for certification from the German Sustainable Building Council (DGNB).

High standards were set for choosing the materials and products and Green Solution House developed its own criteria for material selection, giving priority to certifications and environmental labels. The criteria incorporate many sustainability aspects including recyclability, social responsibility, use of resources, material safety, and energy consumption. Possible producers and suppliers were contacted and alternatives identified for any materials and products not meeting the criteria. As a result, many of the chosen solutions are designed for disassembly, Cradle to Cradle ${ }^{\circledR}$ certified, and have a positive impact beyond their mere function.

The hotel and congress centre sustainability aspect is included in all functions, from cleaning and the menu of the restaurant to the garden and surroundings. Chemicals are being avoided in the housekeeping, and the kitchen utilises local and organic ingredients. A key ambition is to avoid (and minimise) waste as much as possible. The Green Footprints Park around the building was created using a combination of solutions, starting with ensuring the park landscape fits the local climate, flooding is mitigated naturally, biodiversity is maximised and the existing local nature is cherished.

In the future, the income from the business will be primarily used for constant improvement, renovating old buildings, and keeping up with new sustainable solutions.

\subsubsection{Success factors}

Green Solution House has a Green Key certification, an international ecolabel for tourism industry. However, Green Solution House sees the Green Key as the base platform for sustainability, and the aim is to go beyond the criteria for Green Key certification. Green Solution House has indeed incorporated other solutions and certifications for sustainability. A prime example is that the building has just received the German Sustainable Building Council (DGNB) certification - as the first hotel in Denmark - and 
an Active House validation. Additionally, the Green Solution House restaurant has acquired the Bronze certification of "Det Økologiske Spisemærke", the Danish Organic Cuisine Label.

Green Solution House won the Danish EU Environmental Award in 2016. The award is granted first at national level, after which each EU country's winners compete against each other for the European Business award for the environment. Green Solution House won in the category "Sustainable Processes".

The number of hotel nights is used as a success indicator in comparison with the number of hotel nights achieved before the transition to Green Solution House. This indicator was taken into use in 2015, when the hotel nights exceed those prior to transformation. Partly this is directly due to the fact that the opening time has been extended from summer time only. Further analysis of the occupation rate will be done in order to separate professional visits (e.g. conferences) from leisure.

\subsubsection{Key Results and Achievements}

\section{Novelty}

Green Solution House pushes the limits of sustainability using an innovative mind-set and specific knowledge gained from their advisors, suppliers, and companies with new technologies. Green Solution House has become known especially in Europe, and companies with new sustainable solutions offer cooperation. Green Solution House both actively looks for information and has the privilege of being presented with new knowledge. Green Solution House can be seen as a test laboratory for innovative sustainable solutions. All concepts used are scalable, reproducible and adaptable.

\section{Sustainability Impacts}

2016 will be the first year of operation after the building renovation has been finished. Hence, at the time of writing in early 2016, Green Solution House has not yet been able to measure and compare the results of the sustainability improvement (e.g. electricity consumption).

\subsubsection{The Green Solutions}

\section{Energy and waste}

Renewable energy is used through both a) pyrolysis of organic waste, and b) solar cells and photovoltaics integrated into the facades and c) glazed ceilings, such as the Velux Modular Skylight. Energy use is monitored and excess 
energy can be supplied to the Bornholm grid. A swimming pool in the cellar was transformed into an on-site energy storage system to store excess heat. A biological water purification system utilising algae and a landscape-integrated bio-digester underline the ideal of a no-waste-concept.

\section{Daylight and indoor climate}

Daylight is utilised in new innovative ways. Large windowpanes and high energy performance are combined with redirecting light channels. A rotating solar receiver on the roof and solar cables transport daylight. An innovative operating system controls ventilation, indoor climate, energy balance and sun screening.

A variety of solutions contribute to keeping the indoor air healthy. The plants in the Green Wall purify the air and balance humidity levels. Some of the materials capture and neutralise dust and other particles. The carpets used capture fine dust particles in the air - four times more effectively than conventional carpets.

\section{Awareness raising}

Two of the guest rooms have an intelligent climate system, allowing visitors to control the indoor climate, monitor energy and water consumption and see the impact of their stay via a mobile application. The objective is to increase awareness at a personal level and nudge green behaviour.

\section{Recycling}

The "Design for Disassembly" strategy influenced design from the earliest decisions through to final detailing. The approach supports the eventual recycling and reuse of building components. This effectively means putting a value on future sustainable building systems, and seeing construction projects as creation of material banks that will support future generations. In addition, the hotel rooms are fitted with upcycled (i.e. old repurposed) furniture.

\section{Outside areas}

The high water table on the site posed a challenge, but instead of fighting nature and treating this as a problem, the landscape was designed around the element of water. Various watershed designs guide rainwater to seasonal ponds. By using local biotopes the site is kept low maintenance and the planting is left to grow wild, helping to increase biodiversity. Soil and a specific mix of gravel remove pollutants from the rain water. The landscape also features local materials and demonstrates sustainable landscape solutions. 
The "Green Footprints Park" is a bitumen free landscape, and the parking lot demonstrates that it is possible to make a robust paving surface for driving, without asphalt. Where needed, a plant-based binder, called Vegecol, is used as an environmentally friendly alternative to bitumen. Local granite is used as well. The design uses it in all sizes and shapes, making both chips and stone dust useful and minimizing granite waste.

\section{Challenges and potential for further development}

The key challenges were communication and the development of innovative solutions and processes. The different kind of advisors claimed to be innovative but quite often they did "copy and paste" from prior projects, because that is easier and cheaper for them. The communication between the advisors and the strategic partners was challenging due to different experiences and opinions about sustainability. The manager of Green Solution House used considerable time on optimizing communication and being the one who pushed the limits and goals for innovation. 


\title{
1.2 The Green Group in Roskilde University Center Tourism Network
}

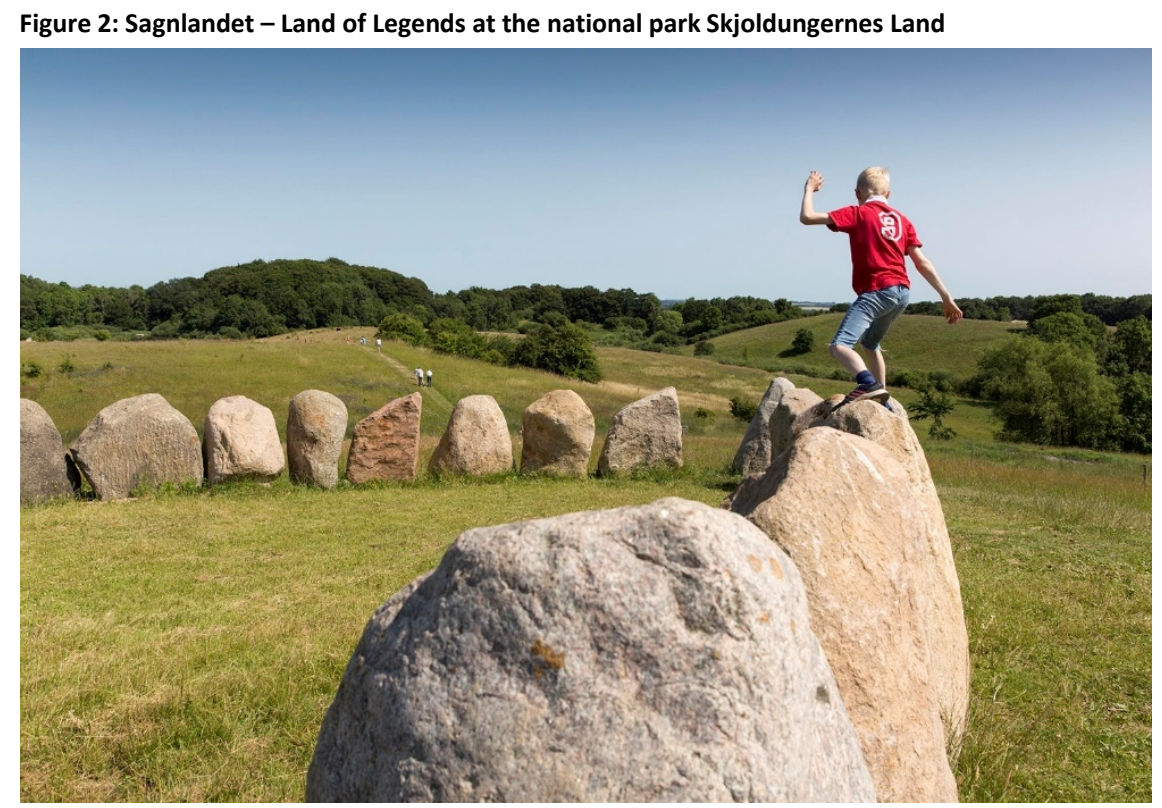

Source: (C) Ole Malling.

\author{
Case Description \\ Country: Denmark (Region: Europe) \\ Geographic scope: Local \\ Theme: $\quad$ Tourism, Sustainable Rural Development, \\ Sustainable Lifestyles and Consumption, \\ Sustainable Production and Value Chains \\ Community: $\quad$ Scientific Knowledge, Sustainable Tourism \\ Type of Initiative: $\quad$ Partnerships and voluntary agreements \\ Lead actor: $\quad$ RUC tourism network \\ Type of lead organization: $\quad$ Partnership/network/consortium

\section{Budget} \\ The Green Group cluster is financed by the region of Sjælland. The funding of ca. \\ EUR 47,000 per year for the three-year project is provided by Vækstforum Sjæl- \\ land (Growth Forum Sjælland).
}




\section{Partners}

The Green Group cluster is part of the RUC Tourism network. The companies in the Green Group in early 2016 included:

- BikeRent.

- Bjørns Naturtjeneste (nature services).

- Café Knarr.

- Fjordland.

- Herthadalen.

- Hesselbjerggaard.

- Landkøkkenet.

- Ledreborg Slot.

- Roskilde Domkirke (cathedral).

- Roskilde Museum.

- Sagens Natur (Nature of Things).

- Sagnlandet Lejre (Land of Legends; museum \& experience centre).

- Selsø Slot.

- Svanholm Storkollektiv.

- Vikingeskibsmuseet (Viking ship museum).

\section{Status}

Started in April 2015. Ongoing.

\section{Next steps}

The Green Group will continue the establishment and development of their products. Planning the next joint conference in November 2016 will also be an important part of their work. The newly developed products of the member companies will be presented at the conference. When the project is finished, scientific articles about the results will be published.

Funding for the Green Group is secured until end of 2016, with follow-up funding being looked for.

Contact person for more information

Anne Cecilie Lasa-González, RUC Tourism Network, annecl@ruc.dk

Note: Case descriptions, e.g. with regards to geographic scope, theme, community, type of initiative, and type of lead organisation, follow the groupings used within UNEP's SCP Clearinghouse. 


\subsubsection{Introduction}

The Green Group in the Roskilde University Center (RUC) Tourism Network is a cluster of 15 tourism companies that are located within or nearby the national park Skjoldungernes Land in Sjælland, Denmark. The national park is located in and around Roskilde, some 30 kilometres from the capital Copenhagen. Skjoldungernes Land was designated a national park in February 2015 and is one of the four national parks in Denmark. The Green Group was initiated by RUC Tourism Network in April 2015. Its member companies are committed to developing and promoting ecotourism, responsible tourism and cultural tourism products in Skjoldungernes Land.

The leader of the Green Group cluster, RUC Tourism Network, is a network operating in the whole Sjælland area in Denmark. RUC Tourism Network consists of over 150 members and aims to promote innovation and economic growth in tourism- and experience economy businesses with the help of research-based knowledge. RUC tourism network is financially supported by the Sjælland region and owned by the Roskilde University.

\subsubsection{Objectives}

The overall aim of the RUC Tourism Network is to generate innovations and growth through research-based knowledge in so-called experience tourism companies in the Sjælland area. The particular objectives of the Green Group cluster are:

- to create new business relations for the member companies

- to develop sustainable ecotourism activities to achieve innovation and sustainable growth

- to implement sustainable processes

- to benefit from the status of the National Park

- to create new research.

The Green Group has an action plan for every year. The action plan for 2015 contained the following goals:

- Member companies of the Green Group cluster sign the contract with RUC tourism network and establish the Green Group.

- The companies get access to new knowledge. 
- The companies sign a letter of intent.

- $75 \%$ of the companies have received inspiration and innovative ideas for their development.

By the end of 2015 all these goals had been achieved and the following goals identified for the action plan for 2016:

- At least $50 \%$ of the companies have developed a new product by end of 2016.

- External and internal evaluation for the Green Group is done.

- Member companies sign a contract that they want to develop a new product.

\subsubsection{Activities}

The Green Group cluster works strategically with research-based knowledge that is chosen for the Green Group based on its member companies' needs. Traditional business practices are questioned and member companies exchange knowledge and cooperate in product development.

The Green Group has four annual meetings, held at the premises of member companies. The meetings begin with a research-based presentation from a researcher from Roskilde University. The topic of the presentation is relevant to the member companies, for example the role of the guides in destination development or communicating and marketing the sustainability of the businesses. After the presentation, the companies work hands-on with a practical example relevant to their business, creating a timeline for their product development and what the steps are to achieve it (e.g. price setting). In addition, personal workshops for companies can be held if needed.

The Green Group works on improving the sustainability of the member businesses. Every product being developed has to have a sustainable dimension to it. The members of the Green Group have to promote and describe in what way the product is sustainable and/or responsible.

\section{Examples of the activities}

A workshop was arranged for a member company creating a recreational spa centre, who met with a researcher experienced in nature and its health effects on e.g. stress.

Herthadalen (a restaurant) and Sagnlandet Lejre (an interactive museum) are working on a project promoting the gastronomic and agricultural history of the National Park. The project combines utilizing local and 
organic ingredients in the modern Nordic cuisine, information on how Vikings lived in synchrony with nature, and storytelling about the National Park area.

Another member of the Green Group is a church that is working to create pilgrim routes in the National Park and hold events in the open.

Other companies are working on a bicycle route where the natural landscape of the park and organic farms will be promoted.

\subsubsection{Success factors}

During 2015, 75\% of the Green Group member companies received inspiration and developed innovative ideas for their business development (the result is based on a questionnaire to the member companies).

For 2016, the set goal is that at least $50 \%$ of the companies shall have developed a new product (by end of 2016).

\subsubsection{Key Results and Achievements}

\section{Novelty}

The Green Group is the first cluster ecotourism initiative taken by a university in Denmark in collaboration with private companies.

\section{Results so far}

The member companies have taken the first steps in their product development. They have had a lot of media attention both in the Danish television and in the form of popularised articles. The annual tourism conference held by RUC Tourism Network was completely sold out in November 2015, with approximately 180 people taking part in it, and the Green Group had a good chance to promote their work and the National Park as such.

\section{Challenges and potential for further development}

In general, the companies have two big challenges: time and marketing. The companies are generally small (SMEs and micro enterprises), who sometimes find it difficult to both run their day-to-day business and develop it at the same time. Marketing is a challenge, because financial ability to pay for marketing is small in small businesses. Therefore, it is sometimes a challenge to see the potential of ecotourism to create business, especially in the micro enterprises. 


\section{Finland}

\subsection{Pyhätunturi - First carbon neutral resort in Nordic countries}

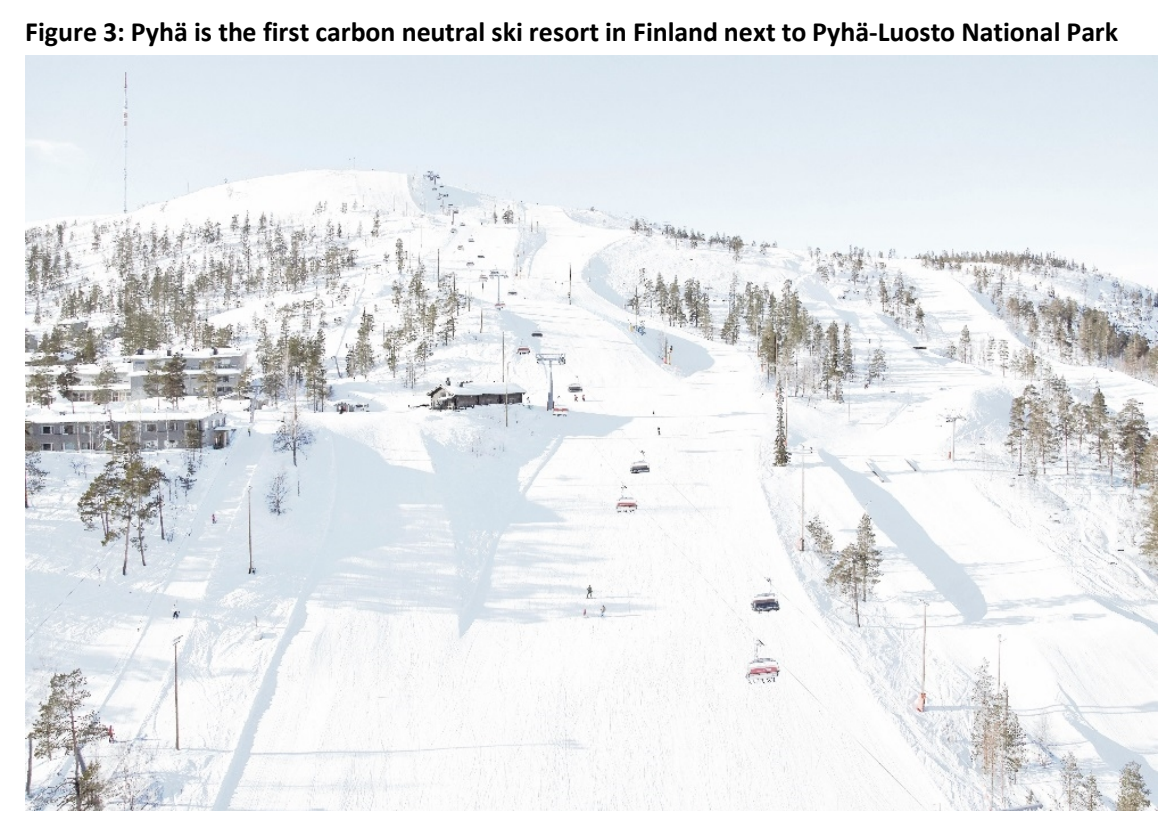

Source: ( Pyhätunturi Ltd.

\section{Case Description}

$\begin{array}{ll}\text { Country: } & \text { Finland (Region: Europe) } \\ \text { Geographic scope: } & \text { Local } \\ \text { Theme: } & \text { Tourism } \\ \text { Community: } & \text { Sustainable Tourism } \\ \text { Type of Initiative: } & \text { Policy frameworks and processes } \\ \text { Lead actor: } & \text { Pyhätunturi Ltd } \\ \text { Type of lead organization: } & \text { Business sector }\end{array}$




\section{Budget}

The estimated development costs of the environmental program for Pyhä were around EUR 30,000. During the implementation of the environmental program over EUR 100,000 was invested in energy efficiency investments. The annual savings from the implemented measures are estimated to be around EUR 10,000.

\section{Partners}

The same environmental program is also followed by Rukakeskus Ltd, the parent company of Pyhätunturi. Rukakeskus Ltd is responsible for the slope operations in Ruka ski resort located in Kuusamo, Finland.

Other important partners are the local energy and waste treatment companies as well as the regional Centre for Economic Development, Transport and the Environment.

\section{Status}

Started in 2008. Ongoing.

\section{Next steps}

Pyhätunturi is updating the environmental program in 2016. The company is working to improve its energy efficiency and keeping an eye on technical development in order to identify new potential improvement areas.

Contact person for more information

Jusu Toivonen, jusu.toivonen@pyha.fi

Note: Case descriptions, e.g. with regards to geographic scope, theme, community, type of initiative, and type of lead organisation, follow the groupings used within UNEP's SCP Clearinghouse.

\subsubsection{Introduction}

Pyhätunturi Ltd (later Pyhätunturi) has applied sustainable practices since early 2000 . The development of environmentally sustainable practices is management driven, who feel it is their moral responsibility to take action on climate change. Keeping the winters snowy and cool as well as preserving the surrounding nature is essential for the company's future business success. The area development plan of the ski resort has been prepared with the sustainability requirements in mind, for example noting the ecological carrying capacity and transportation needs. In 2008, 
an environmental program, including specific targets, measures and responsibilities, was drawn up for Pyhätunturi. The environmental program is applied to Pyhätunturi's slope activities, restaurants as well as Ski-Inn accommodation, and it has resulted in energy and cost savings. Pyhätunturi is purchasing carbon neutral electricity and heat. Carbon emissions from fuel use in slope machines are compensated through Gold Standard certified wind and hydropower emission reduction projects. Pyhätunturi is the first carbon neutral ski resort in Nordic countries.

\subsubsection{Objectives}

The objective of the environmentally sustainable development program in Pyhätunturi is to sustain the surrounding nature and ensure future profitable business opportunities.

\subsubsection{Activities}

In 2008, Pyhätunturi, the company responsible for the slope operations and Ski-Inn accommodation services at Pyhä ski resort, developed an environmental program. Pyhätunturi started the development and implementation of the environmental program by training the employees. A club called "Green Flake", which organizes special events for the members, was founded to motivate personnel to green actions. In order to gain membership in the club, an employee has to suggest or perform an action that improves sustainability.

Before drafting targets for the environmental program, Pyhätunturi reviewed its energy consumption. $65 \%$ of electricity was found to be consumed in slope operations. Therefore, targets were set to especially improve the energy efficiency of slope machines such as snow cannons and lightning. Reduction targets were also set for the fuel consumption of snowmobiles and piste grooming machines. Investments were made in new more energy efficient machines. Appropriate use of the machines plays a key role in fuel consumption, and therefore the company also launched a program linking incentives to saving fuel. Slope personnel were rewarded with half of the savings achieved through reduced fuel consumption. The combination of the incentive program and introduction of new practices has led to considerable fuel savings. 
When a new district heating utility was built in 2010, Pyhätunturi suggested a biofuel plant. In addition to using carbon neutral heat, Pyhätunturi uses electricity made from renewable energy sources. The company has also looked for possibilities to utilize bio fuels in the slope machines but so far, solutions suitable for the cold conditions have not been found.

Since 2010, Pyhätunturi has compensated CO2 emissions from fuel use in the slope machines through Nordic Offset. The compensation has been directed to Gold Standard certified wind and hydropower projects. The company is following the development of electric snowmobiles and plans to test these when they become available.

The company policy is to avoid unnecessary business travel, and emissions from necessary flights are compensated. Pyhätunturi has also set targets for recycling and water consumption. Pyhätunturi organizes annual seminars for local entrepreneurs and public decision makers in order to raise awareness about sustainable development.

\subsubsection{Success factors}

Management commitment is seen as one of the main success factors. In the beginning, the management invested resources in the development by hiring a person solely dedicated to develop and implement the environmental program.

In 2011, Pyhä was selected as the Finnish Ski center of the year. One of the main reasons for the selection was the long-term work for sustainable development.

\subsubsection{Key Results and Achievements}

\section{Novelty}

Pyhätunturi is the first carbon neutral ski resort in Nordic countries.

\section{Sustainability Impacts}

Pyhätunturi has indicators with set targets for energy and water consumption. Since 2008, the energy efficiency of slope operations has improved by $6 \%$ (reduction in electricity used) and the fuel consumption of slope machines has been reduced by $50 \%$. 
Pyhätunturi follows how the company image as an environmentally sustainable ski center has developed through surveys for personnel and customers. According to the latest customer survey conducted in 2016, company image as an environmentally sustainable ski center has improved by $20 \%$ compared to the previous survey conducted in 2015 .

Pyhätunturi is carbon neutral with regards to its consumption of purchased electricity and heat as well as fuel consumption in slope operations. The carbon emissions from fuel use in slope machines is offset through Gold Standard certified emission reduction project in Turkey and China.

Energy efficiency improvements have resulted in cost savings. In addition, new technology has resulted cost-savings due to increased automation for example related to snow cannons. The new snow cannons turn on and off automatically based on optimal snow making weather conditions.

\section{Challenges and potential for further development}

Before 2008, the ski center was not actively developed and new practices were not applied. Therefore, in the beginning of the environmental program development, the existing organizational culture and attitudes of the personnel were making implementation of new practices slow. Hence, involving employees in the environmental program development and implementation from the beginning is seen as crucial to the success. 


\subsection{Metsähallitus Parks \& Wildlife Finland - Sustainable nature tourism}

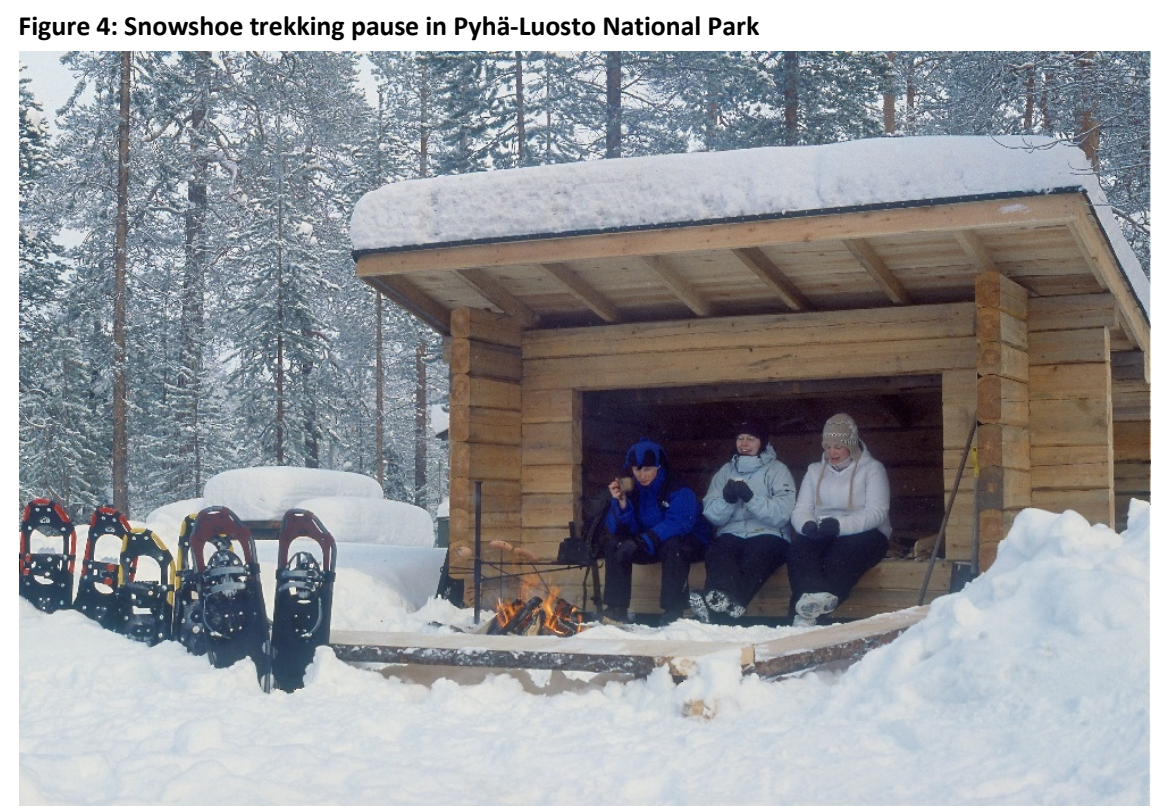

Source: (C) Tapani Vartiainen.

\section{Case Description}

$\begin{array}{ll}\text { Country: } & \text { Finland (Region: Europe) } \\ \text { Geographic scope: } & \text { National } \\ \text { Theme: } & \text { Tourism } \\ \text { Communities: } & \text { Sustainable Tourism } \\ \text { Type of Initiative: } & \text { Partnerships and voluntary agreements } \\ \text { Lead actor: } & \text { Metsähallitus Parks \& Wildlife Finland } \\ \text { Type of lead organization: } & \text { Public institution }\end{array}$

\section{Partners}

Sustainable tourism is promoted in co-operation with local residents, local authorities, companies offering tourist services, and other organisations.

\section{Status}

Started in 2004. Ongoing. 


\section{Next steps}

Metsähallitus P\&WF has recently renewed the principles of sustainable tourism and widened the scope from national parks, nature sites and historical sites to also include UNESCO World Heritage Sites in Finland

Contact person for more information

Joel Erkkonen, joel.erkkonen@metsa.fi

Note: Case descriptions, e.g. with regards to geographic scope, theme, community, type of initiative, and type of lead organisation, follow the groupings used within UNEP's SCP Clearinghouse.

\subsubsection{Introduction}

Metsähallitus Parks \& Wildlife Finland (later Metsähallitus P\&WF) manages most of Finland's 39 national parks and other protected areas on land owned by the state. Many of Finland's protected areas are significant tourist attractions. To help improve nature tourism in a sustainable manner, Metsähallitus P\&WF already in 2004 developed a specific set of principles for sustainable tourism in protected areas, wilderness areas and sites in special conservation programmes. Based on these principles, Metsähallitus P\&WF enter into written cooperation agreements with local companies, in which acceptable and sustainable practices for the area is defined. In the beginning of 2016, some 520 cooperation agreements between Metsähallitus P\&WF and local companies were in force. These cooperation agreements have led to better monitoring of the sustainability of the companies' activities in protected areas as well as increased knowledge of sustainable tourism among companies and visitors. Metsähallitus P\&WF also promotes volunteer work combined with an outdoors holiday.

\subsubsection{Objectives}

Metsähallitus P\&WF aims to promote sustainable tourism in protected areas, wilderness areas and sites in special conservation programmes in cooperation with other interest groups, without jeopardizing the protection goals. 


\subsubsection{Activities}

In 2004, Metsähallitus P\&WF implemented a specific set of principles for sustainable tourism in protected areas, wilderness areas and sites in special conservation programmes. These principles are implemented at local and company level. The principles may be adapted to local conditions and followed in different ways by different organisations. The principles of sustainable tourism in protected areas, wilderness areas and sites in special conservation programmes have been updated in 2016 in cooperation with UNESCO World Heritage Sites in Finland and they are as follows:

- We promote sustainable tourism. In order to achieve this goal, we cooperate to:

- support the preservation of valuable features at the sites and promote their protection

- minimise the load on the environment

- strengthen local aspects

- promote use of the sites to increase health and well-being

- promote growth and job creation in the local economy

- communicate together the values and services of the site.

At local level, these principles are used as a basis for sustainable tourism development strategy. The sustainable tourism development strategy is designed to assist area planners and entrepreneurs. The sustainable tourism development strategy defines how the area can be used in tourism and highlights what are the future development needs. To follow-up how the principles of sustainable tourism have been fulfilled, Metsähallitus P\&WF has developed a set of indicators based on The Limits of Acceptable Change (LAC). The LAC planning system was developed in the USA over a period of years in the early 1980s to address the problems of managing recreational use in national protected areas. The indicators and limits are set at local level and Metsähallitus P\&WF has planned preventive measures to avoid exceeding the LAC.

At company level, Metsähallitus P\&WF enters into written agreements with companies, which operate in the areas managed by Metsähallitus P\&WF, to define acceptable and sustainable practices. The principles of sustainable tourism form the basis of these agreements. Adjacent to the agreements, Metsähallitus P\&WF provides a practical guide for companies on how to implement the principles in practice. Metsähallitus P\&WF 
collects feedback annually from companies about how they perceive sustainability has developed. Additionally, Metsähallitus P\&WF cooperates with companies in product development and participates in different events. Metsähallitus P\&WF also trains local guides in guiding services in protected areas.

In addition to corporate cooperation, Metsähallitus P\&WF also actively raises awareness on ecosystems. Metsähallitus P\&WF promotes volunteer work combined with an outdoors holiday. For example, during sheep herding weeks, volunteer workers can learn how to take care of sheep and simultaneously enjoy the picturesque landscapes surrounding the beautiful farms located in the national parks and protected areas. The sheep on the other hand, keep meadows and heritage landscapes open protecting their traditional flora and fauna.

Metsähallitus P\&WF also collects visitation numbers of the most popular state-owned protected areas and hiking areas under its administration. Based on the data collection, the financial value of visitor spending for local economy and for public health is also evaluated.

\subsubsection{Success factors}

National level coordination of the protected areas by Metsähallitus P\&WF has enabled nationwide implementation of the principles of sustainable tourism, agreements with companies and follow-up studies.

\subsubsection{Key Results and Achievements}

\section{Novelty}

Metsähallitus P\&WF has been a global level forerunner in creating the principles of sustainable tourism and implementing them through agreements with companies since 2004 .

\section{Sustainability Impacts}

In the beginning of 2016, there were around 520 cooperation agreements between Metsähallitus P\&WF and companies involved. The contracts have resulted in better overview of and control over company activities in protected areas. Mutual benefits have arisen from cooperation in marketing and communication activities.

Local economies benefit from funds granted by the Finnish government for national parks and hiking areas. It has been estimated that these funds return to society many-folded through local entrepreneurship and jobs. In 2015 , the total number of visits in national parks, national hiking areas and 
some other protected recreational areas was nearly 4 million. Solely in the 39 national parks, the total income and job impacts were EUR 141.5 million and about 1,400 jobs (full-time equivalent) and for all the 6 hiking areas EUR 12.2 million and about 131 jobs (FTE) in 2015. The biggest local economic impacts can be seen in tourism centres where the visitors stay for a longer period and the supply of tourism services is larger.

In 2013, the impact of visiting national parks and other state-owned protected areas on the social, psychological and physical wellbeing benefits perceived by visitors were studied for the first time in Finland. Park visits were found to improve the mood and enhance the psychological well-being in particular. They were also perceived to help recovery from stress.

The input-output ratio of the national parks is good. National parks return EUR 10 to the local economies for every EUR invested by the Finnish taxpayer. The self-defined value of health benefits experienced by all Finnish national park visitors in 2013 has been calculated in Metsähallitus reports at EUR 226 million in total.

\subsubsection{Challenges and potential for further development}

While implementing the principles of sustainable tourism and agreements in 2004, Metsähallitus P\&WF encountered some resistance from companies. Some of the companies perceived that it is their right to use the Metsähallitus P\&WF facilities, such as campsites, compost toilets, wells and campfire sites in protected areas free of charge. Over the years, the companies have understood the mutual benefits of cooperation. Also Metsähallitus P\&WF has changed its practices to a more cooperative way. However, few companies still exist that use the Metsähallitus P\&WF facilities free of charge thinking that it is part of their everyman's right. Finland's legal concept of everyman's right gives everyone the chance to enjoy the Finnish countryside with few restrictions.

Metsähallitus P\&WF found that the first set of indicators for evaluating the sustainability of nature tourism were too complex and many of them did not necessarily measure the effects of tourism. Hence, after couple of years of usage, Metsähallitus P\&WF simplified the indicators and nowadays they are formulated area specifically in the sustainable tourism development strategies.

Potentials for development have also been identified to improve the cost-effectiveness and lead-times of administering the agreements with companies. 


\section{Faeroe Islands}

\subsection{Lakeside Excursions}

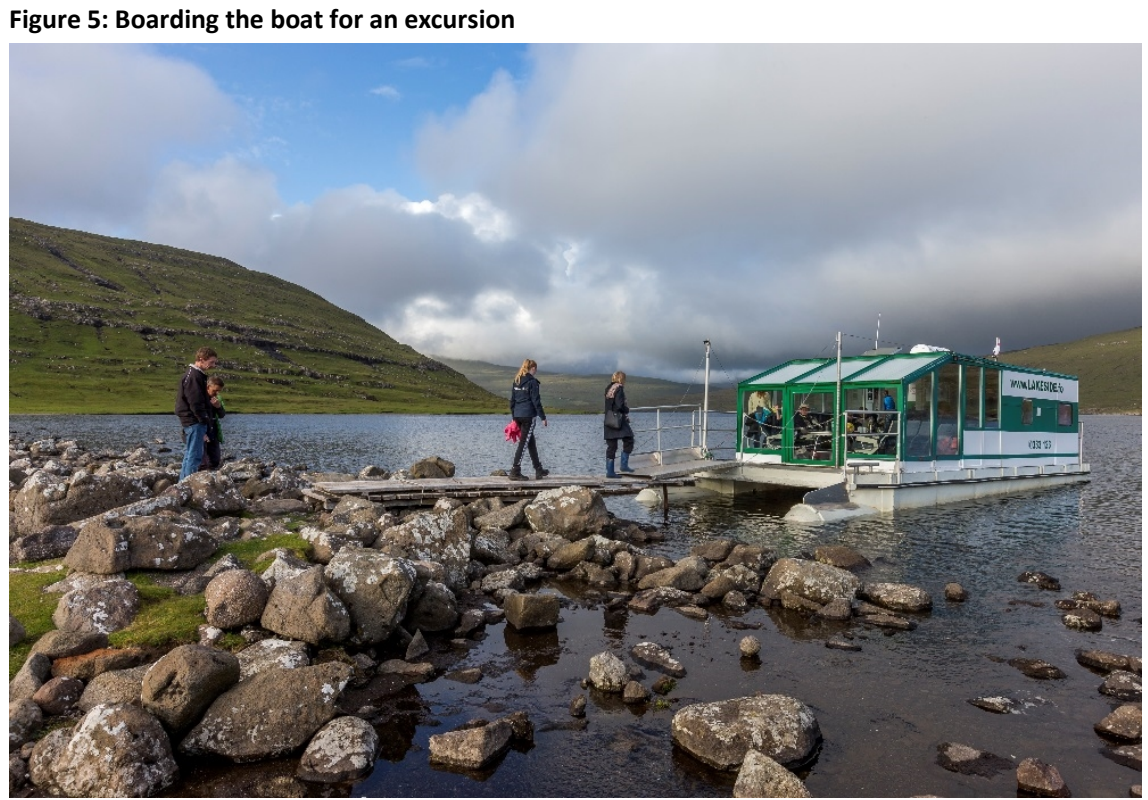

Source: (c) Faroephoto.com

$\begin{array}{ll}\text { Case Description } & \\ \text { Country: } & \text { Faroe Islands (Region: Europe) } \\ \text { Geographic scope: } & \text { Local } \\ \text { Theme: } & \text { Tourism } \\ \text { Communities: } & \text { Sustainable Tourism } \\ \text { Type of Initiative: } & \text { Information, awareness-raising, education } \\ \text { Lead actor: } & \text { Ólavur Poulsen/Lakeside excursions } \\ \text { Type of lead organization: } & \text { Business sector }\end{array}$




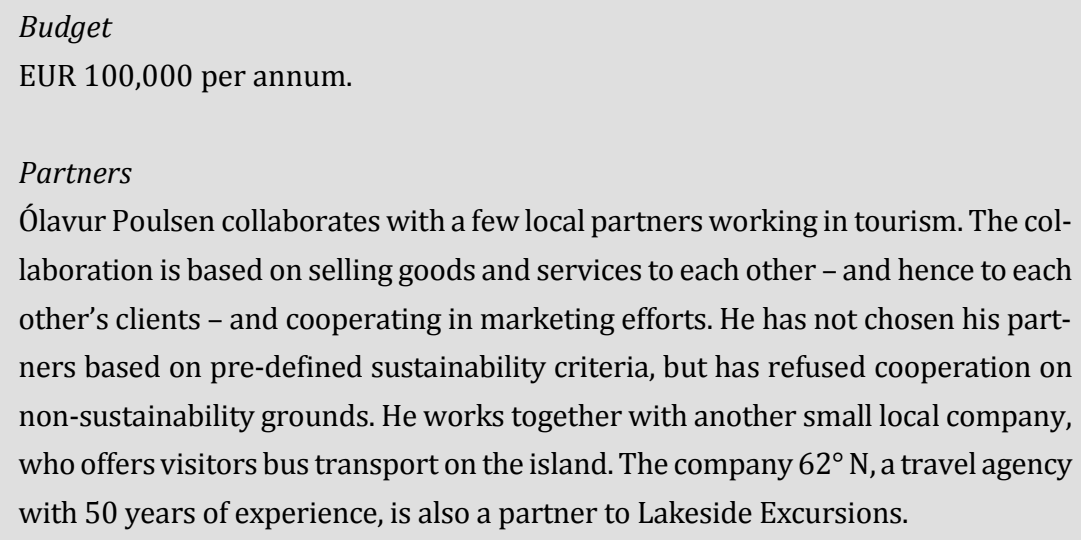

Status

Started in 2005. Ongoing.

\section{Next steps}

Serving sustainable food on the excursions is one goal for the future.

When he has the possibility to make the investment, Ólavur Poulsen aims to use the electric propulsion system created by the RENSEA project on a new 48-passenger vessel with an electric motor. This would increase the overall sustainability of his business, as $60 \%$ of the electricity produced on the Faroe Island is Green energy. By 2030, Faroe Islands aims to achieve 100\% Green energy production.

Contact person for more information

ólavur Poulsen, lakeside@lakeside.fo

NOTE: Case descriptions, e.g. with regards to geographic scope, theme, community, type of initiative, and type of lead organisation, follow the groupings used within UNEP's SCP Clearinghouse.

\subsubsection{Introduction}

Lakeside Excursions is a small company, arranging excursions on Faeroe Islands' largest lake, Sørvagsvatn, also called Leitisvatn. Lakeside Excursions is situated in Vatnsoyrar, a small village in the middle of the Faroese island of Vagar. It is the only village in the archipelago that is not on the seacoast.

Lakeside Excursions aims to give their customers a unique experience on the lake on sustainable terms, in a manner not disturbing the nature, 
running with a silent motor, and telling the customers about the nature and sustainability. The landscape, nature and wildlife is almost unspoiled by man, making the importance of protecting this place high priority.

\subsubsection{Objectives}

Lakeside Excursions wishes to be an example of sustainable tourism on the Faroe Islands. Customers are given a nature experience and information on sustainability. The goal is to let customers enjoy nature sustainably and to understand its value - both to locals and to tourists as well as its value as nature itself.

\subsubsection{Activities}

The Owner Ólavur Poulsen became interested in environmental protection and sustainability while educating himself in Iceland. Gradually nature and sustainability became a large part of his life and led him to start his own sustainable nature tourism business. In the Faroe Islands, nature conservation regulation is limited. Therefore, any sustainability aspects of tourism and nature activities are to a large degree dependent on the organisers.

Lakeside Excursions started with arranging tours on the lake to visit the waterfall, a site that is also popular with the locals. Due to financial constraints, Ólavur Poulsen had to be innovative in accessing a suitable boat for his tourism activities. He built his boat by combining secondhand materials, using an old catamaran acquired from a salmon farmer as the base, constructing the cabin on the deck from a small greenhouse, a bus stop shelter, and a caravan. The chairs on board are from an airplane. A new engine was bought for the boat to be both more silent and pollute less. In order to improve the quality of the excursions, Lakeside Excursions has been part of a Nordic project called RENSEA since spring 2012. RENSEA is a project creating a regenerative hybrid-electric propulsion system, with the objective to develop a silent and non-polluting engine for nature adventure boats. Ólavur Poulsen hopes to have a chance to promote the project on Faroe Islands with the help of the bigger partners in the project.

Ólavur Poulsen has also taken part in development projects. In 20132014, he took part in a project lead by the University of the Highlands and Islands, Scotland, about Slow Adventure. In the project, he envisioned how slow, sustainable adventure tourism could be a part of Faroe Islands' tourism and how such activities could benefit from being marketed as such. 


\subsubsection{Success factors}

Ólavur Poulsen feels that the reason for his success is his responsible behaviour, which makes his customers feel safe, and his enthusiasm, respect for the environment and sustainability principles. He measures his success from the number of tours booked and passengers on them, and by his financial result.

\subsubsection{Key Results and Achievements}

\section{Sustainability Impacts}

Ólavur Poulsen wishes to provide his customers with an experience of the beautiful pristine nature of the Faroe Islands and telling them about sustainability. Ólavur Poulsen has not measured his impact, but he has received generally positive feedback from his customers, who thank him for being made aware of the nature, wildlife and sustainability. Ólavur Poulsen has also been on the national radio and is active in social media. Lakeside Excursions has about 1,000-1,500 customers annually. There is no registration of sustainable nature tourism enterprises in the Faroe Islands, but the number of enterprises claiming to be sustainable nature tourism businesses or similar is growing. It is estimated that there are approximately 5-10 nature tourism enterprises in the Faroe Islands.

Ólavur Poulsen's sustainability principles include minimising the noise and pollution created by his boat excursions by keeping the speed very low, at 4-6 knots. This way his excursions disturb the wildlife and neighbouring residents as little as possible. Simultaneously, the fuel consumption of his boat is very low.

\section{Challenges and potential for further development}

The greatest challenge in the beginning was to have a boat big enough and suitable for the excursions. The tourism has been growing slowly in Faroe Islands, so also the income and possibilities to invest are small. Luckily, this means that tourism is not straining the nature too much. 


\section{Iceland}

\subsection{North Sailing - Sustainable Whale Watching}

\section{Figure 6: Opal sailing in Greenland}



Source: (C) North Sailing.

$\begin{array}{ll}\text { Case Description } & \\ \text { Country: } & \text { Iceland (Region: Europe) } \\ \text { Geographic scope: } & \text { Sub-regional } \\ \text { Theme: } & \begin{array}{l}\text { Tourism, Energy, Sustainable Rural Devel- } \\ \text { opment, Transport and Mobility }\end{array} \\ \text { Community: } & \text { Sustainable tourism } \\ \text { Type of Initiative: } & \text { Information, awareness-raising, education } \\ \text { Lead actor: } & \text { North Sailing } \\ \text { Type of lead organization: } & \text { Business sector }\end{array}$




\section{Budget}

The budget for project development, installing and evaluating the Regenerative Plug-In Hybrid Propulsion System into the ship Opal was mainly provided by Noth Sailing, as the owner of Opal. A number of local and international partners provided some $20 \%$ of the required investment, mainly covered through a grant, jointly applied for.

\section{Partners}

The University of Iceland has a small department in Husavik focused on marine research. North Sailing supplies researchers with boats and sometimes the researchers come along on the tours to tell about their research. North Sailing also cooperates with the whale museum in Husavik, providing its researchers use of their boats.

North Sailing also cooperates with shipyards in Scandinavia to share knowledge about traditional shipbuilding and restoration of old vessels.

The development of the Regenerative Plug-In Hybrid Propulsion System was achieved in cooperation with the projects Nordic Marina and RENSEA (Clean oceans). The design criteria in the projects were to be able to conduct a 4-hour whale-watching trip on batteries, and a Greenland excursion when combined with sails. North Sailing's partners are:

- Charging/recharging: Naustmarine (Iceland) and Clean e-Marine (Denmark).

- Propeller: Caterpillar Propulsion (Sweden) and Wave Propulsion (Norway).

- Batteries: Lithium Storage (Switzerland).

- Electric Motor/Generator: Baumuller (Netherlands).

- Bellona and ANEL (Norway), Iceland's Innovation Center and Icelandic New Energy, Lakeside excursions (Faroe Islands).

\section{Status}

Started in 1995. Ongoing.

\section{Next steps}

North Sailing is launching the second ship with an electrical engine in July 2016. The ship used to be a whale-hunting vessel that sank in the Sandgerdi harbor some years ago. Now it is being restored and given a new second chance as an eco-friendly whale watching vessel. The ship has no sails, but will be used with Iceland's green electricity for voyages in the Skjálfandi Bay. It will be the ninth ship in their fleet.

By 2020, the whole company aims to be completely carbon neutral, using electric propulsion on day tours and hybrid regenerative systems and diesel as 
emergency power on longer expeditions where possible. North Sailing is also thinking about building a new boat, since not so many old boats are available anymore.

\section{Contact person for more information}

Gudbjartur Ellert Jonsson. Managing Director, North Sailing.

bjartur@northsailing.is

Note: Case descriptions, e.g. with regards to geographic scope, theme, community, type of initiative, and type of lead organisation, follow the groupings used within UNEP's SCP Clearinghouse.

\subsubsection{Introduction}

Since 1995, North Sailing offers Whale Watching tours from Northern Iceland. The tours start from Husavik to the Skjálfandi Bay or from Hjalteyri to see the Eyjafjörður fjord. In addition, week-long tours to Greenland to experience the Scoresby Sund fjord are offered. All North Sailing ships are restored vessels given a new life.

North Sailing respects the nature and strives to be sustainable in every way - from using local food and old wooden vessels to taking part in technical development and retrofitting their ships with electric engines. Due to their development project that created a Regenerative Plug-In Hybrid Propulsion System, they are able to offer carbon neutral whale watching.

North Sailing also participates in research, and respect the birds and other wildlife in the area. North Sailing has received several awards, both nationally and internationally, for their activities in sustainable tourism, carbon footprint reduction and regional development.

\subsubsection{Objectives}

North Sailing aims to provide its customers with a sustainable, respectful and climate-friendly way to enjoy the northern marine environment. Their customers increasingly show desire for sustainable, clean excursions and minimization of the ecological footprint of the holiday. North Sailing aims to meet this demand by innovative means and simultaneously preserving the competitive edge, image and brand-value of North Sailing.

North Sailing is aiming to be sustainable in every action they take and their goal is to be completely carbon free by 2020 . The objective is that their customers, as well as other tourists who learn about sustainable 
tourism options, will contribute towards increasing environmental awareness and creating a more sustainable tourism market by requesting carbon neutral tours.

\subsubsection{Activities}

\section{Nature friendly operation}

North Sailing actively implements their environmental policy. Respect for nature and focus on sustainability form the base in every decision. North Sailing adheres to a strict code of conduct for responsible whale watching. Noise pollution is minimized using wooden ships and slowing down in the vicinity of whales. When using sails or an electric engine, the ship is almost silent, reducing disturbance to the whales and other wildlife. North Sailing also participates in whale research to help protect the species and their natural habitats. North Sailing opposes whale killing and supports the protection of endangered species by being a partner of IFAW - International Fund for Animal Welfare. In addition to the whales, they also know the birds and other wildlife in the area and offer their guests knowledge about them.

\section{Renewable energy}

North Sailing has been the main actor and coordinator in an international research project developing a Regenerative Plug-In Hybrid Propulsion System for sailing boats. The project started in 2012 and reached its goal on July 12th 2015 when their sailing ship Opal was launched after its renovation. Opal is the first ship in the world on which this system has been installed. It basically enables recharging of the ship's batteries while sailing by generating electricity with the propeller. The energy can be stored in the batteries for calm days. When docked, the ship's batteries are recharged with Icelandic green energy. As no fossil fuels are used, a voyage with this ship is carbon free. The newly developed technology is transferable and scalable. The second ship is to be fitted with an electric engine in July 2016. North Sailing's aim is that all day tours - the biggest part of their operations - will be driven by electricity only. However, all ships will still have a small emergency diesel engine that can generate electricity if there is not enough wind and the ship is in such a remote area that charging the batteries is not possible.

As the North Sailing fleet needs maintenance every year, a certain amount of North Sailing's budget is reserved for each boat yearly. The maintenance done on the ship Opal due to the project was within ex- 
pected limits. North Sailing believes that the total cost of installing electrical systems is similar to having new motors and other equipment installed boats running on fossil fuel. The benefit of carbon-free systems is likely to make their business more attractive compared to competitors using fossil fuel.

\section{Preserving cultural heritage}

From the beginning, North Sailing has been dedicated to preserve the Icelandic coastal culture by salvaging and renovating old oak ships. Once common wooden fishing ships are rare today. Restoration of old vessels maintains traditional shipbuilding craftsmanship. North Sailing's sailing ships are today the only traditional gaff rigged sailing ships in Iceland and therefore play an important role in preserving knowledge of handling and maintaining a traditional sailing vessel.

North Sailing also preserves cultural heritage of the small fishing village Húsavík by giving new purpose to the historical waterfront buildings. Restaurant Gamli Baukur is owned by North Sailing and is a replica of a historical building and built using driftwood collected locally. The café Hvalbakur has a unique interior made of remains of old boats.

\section{Local food}

Restaurant Gamli Baukur's menu focuses on the daily catch of the local fishermen and the meat is from local farmers. Both the restaurant Gamli Baukur and the café Hvalbakur are whale friendly - meaning that North Sailing supports the "Meet Us Don't Eat Us" project, which encourages tourists to enjoy whales in their natural habitat rather than on their plate.

\subsubsection{Success factors}

North Sailing has received several awards since the start of operations, including several awards for innovativeness as well as awards for environmental policy and regional development efforts. Being a pioneer and achieving the means of non-weather dependent carbon neutral ship expeditions is a one-of-a-kind result - as are the 70,000 customers that yearly board their vessels. The success stems from the beginning of the company and the culture that the founders have instilled in relation to both coastal culture and environmental issues. The company was initially founded to salvage and repair old Icelandic oak fishing vessels. This has been an important factor for the preservation of cultural heritage. The only traditionally rigged sailing ships in Iceland are owned and restored by North Sailing. The company culture to date is based on ideas and values that strive for sustainability in operations. 
North Sailing has received following awards:

- 2016 Finalist in Innovation at the WTTC Tourism for Tomorrow Awards.

- 2015 World Responsible Tourism, Silver Awards - Best Innovation for Carbon Reduction.

- 2015 The Environmental Award from the Icelandic Tourist Board.

- 2015 Company of the Year selected by Visit North Iceland.

- 2013-2015 Tripadvisor® Certificate of Excellence winner and the highest rating for activities in the destination.

- 2014 Landstólpinn - Icelandic Regional Development Institute Awards for the development of whale watching in Húsavík.

- 2010 Icelandic Web Awards.

- 2007 The Innovation Award from the Icelandic Travel Industry.

- 2003 Scandinavian Travel Award.

- 1996 Silver Otter Award from the British Guild of Travel Writers.

- 1996 The Environmental Award from the Icelandic Tourist Board.

\subsubsection{Key Results and Achievements}

\section{Novelty}

North Sailing is a pioneer in sustainable tourism, always looking for improvement and innovation in order to satisfy the increasingly environmentally concerned customers, whilst not forgetting the whales and the other wildlife. In cooperation with several partners, they have developed a specifically designed Regenerative Plug-In Hybrid Propulsion System. One sailing ship, Opal, has been refitted with that system. It enables recharging the ship's batteries while sailing and storing the energy for calm days. The innovation minimizes the environmental footprint of the tour and offers a unique experience to the passengers by carrying them silently through the fragile habitat of whales, arctic birds and polar bears. With Opal, North Sailing can already offer carbon neutral tours.

\section{Sustainability Impacts}

North Sailing works on increasing sustainable tourism and environmental awareness, whilst giving their customers a chance to experience the arctic nature as silent spectators with a minimal environmental footprint. 


\section{Impacts on people and other businesses}

North Sailing is owned and run by a local family in Húsavík. Three generations take part in daily operation and the fourth one is already lending a hand. North sailing is an important supplier of jobs in Húsavík, a village of 2,300 inhabitants. As the clients of North Sailing also need other services, possibilities are also created for other local businesses, including accommodation, restaurant, and other activities such as horse riding. The technology development project created opportunities for technicians, electricians and engineers. People directly affected are the employees of North Sailing, the inhabitants of the region and more than 70,000 passengers yearly.

\section{Challenges and potential for further development}

North Sailing has been able to finish the Regenerative Plug-In Hybrid Propulsion System project in a small fishing village, which shows that a similar project can be done elsewhere, too. Of course, the project also presented challenges, such as technical problems, but focusing on the goals and keeping things simple made them succeed. The awards North Sailing has received are encouraging them to renovate further ships -the second ship fitted with an electrical engine will be launched in July 2016. 



\section{Norway}

\subsection{Destination Røros - award winning Sustainable Destination}

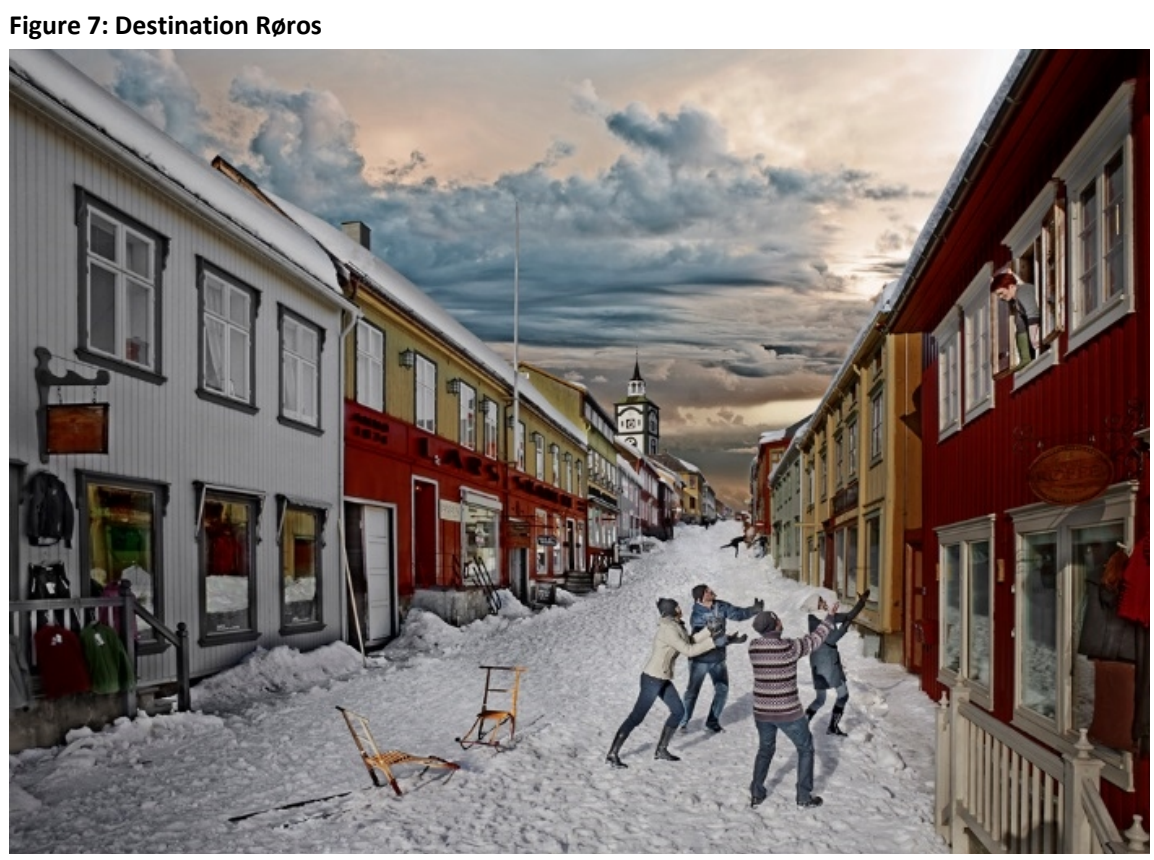

Source: CTom Gustavsen.
Case Description
Country:
Norway (Region: Europe)
Geographic scope:
Local
Theme:
Tourism, Sustainable Rural Development, Awareness-raising and Education for SCP
Type of Initiative:
Partnerships and voluntary agreements
Lead actor:
Destination Røros
Type of lead organization:
Business sector 


\section{Budget}

Destination Røros received a total of ca EUR 160,000 from Innovation Norway during the three-year pilot project period. Development is today done through different projects supported by a variety of financing institutions. Revenue collected as membership fees from the participating companies goes fully towards marketing activities.

\section{Partners}

In Norway, Innovation Norway sets the course for Sustainable Destination development and has provided Destination Røros with detailed advice on environmental sustainability. Accordingly, Innovation Norway has been an important partner for Destination Røros at the national level. At local level, the main partners have been the collaboration of local food producers, Rørosmat as well as the Røros Museum and World Heritage and local businesses.

\section{Status}

Started in 2007. Ongoing.

\section{Next steps}

Sustainable Destinations certificate by Innovation Norway needs to be renewed every three years. Destination Røros is currently (spring 2016) undergoing the recertification process.

The strategy of Destination Røros is to constantly improve the sustainability of the destination and innovate new sustainable products, such as related to ecological food. Additionally, the goal is to encourage even more companies to apply for an environmental certificate and to train more people.

\section{Contact person for more information}

- Linda Ramberg, Destination Director, linda.ramberg@rorosinfo.com

- Hilde Bergebakken, former Sustainable Development Manager, hilde.bergebakken@roros.net

Note: Case descriptions, e.g. with regards to geographic scope, theme, community, type of initiative, and type of lead organisation, follow the groupings used within UNEP's SCP Clearinghouse. 


\subsubsection{Introduction}

Destination Røros is an early adopter of sustainable tourism. It has been involved in setting the course for holistic thinking in Norwegian tourism. For the 3,700 inhabitants World Heritage mining town Røros, sustainability is about protecting nature, culture and the environment while strengthening social values and ensuring economic viability. Through a holistic system, that evaluates, trains, and develops the destination and its members, Destination Røros continues to implement best practices within sustainable tourism. Destination Røros works with over 180 member organisations in order to encourage the cooperation of tourism and its development throughout the region in a sustainable manner. It has won global sustainable tourism awards such as Responsible Tourism Awards and the Tourism for Tomorrow Awards. Additionally, Røros has reached the National Geograpic World Legacy Awards Final.

\subsubsection{Objectives}

The objective of the sustainable tourism destination development was to create value through increasing the attractiveness of the World Heritage Site Røros Mining Town and The Circumference in sustainable manner.

\subsubsection{Activities}

Destination Røros and the local businesses faced severe financial difficulties in 2006. In 2007, Destination Røros elected a new board, which launched a new strategy focusing on the World Heritage and Sustainable tourism. The World Heritage status was seen as the most important asset in order to differentiate Røros in relation to other destinations. Sustainable tourism development was perceived to be fundamental for conserving the cultural heritage and natural surroundings as well as ensuring profitable business.

In 2009, Destination Røros was granted funds as the national pilot for sustainable tourism by Innovation Norway. The Røros pilot project was based on a partnership in the local community, with interaction with Røros borough council, Røros Museum, local food producers, tourism industry and many other business sectors, as well as interaction with other boroughs in the region. During the pilot project, Røros invested in environmental improvements, local food and sustainable value creation. The holistic development approach is based on The World Tourism Organiza- 
tion's (UNWTO) definition of sustainable tourism. In 2013, the municipality of Røros was one of the first four locations certified as a Sustainable Destination by Innovation Norway.

Today Destination Røros works with around 180 member organisations in order to encourage the cooperation and coordination of tourism and its development throughout the region in a sustainable manner. Destination Røros has adopted a forward-looking sustainability policy, and actively encourages companies to go through an environmental certification process. The companies may freely choose the certification that best suits their needs. Additionally, Destination Røros communicates the sustainability efforts, for instance in its promotional materials, and encourages visitors to act in a sustainable manner.

\subsubsection{Success factors}

In 2013, Røros received the prestigious Sustainable Destinations-certificate, a quality label awarded by Innovation Norway to destinations that work systematically to reduce the environmental impact of tourism while maintaining a high-quality experience for visitors, as well as preserving the destination's history, character and nature.

Destination Røros is the only Norwegian destination that has reached the final of the three most prestigious sustainability awards in the world:

- In 2011, Destination Røros was awarded "Best Destination" in the Responsible Tourism Awards organised by responsibletravel.com

- In 2012, Destination Røros won in the category "Destination Stewardship" in the Tourism for Tomorrow Awards.

- In 2016, Destination Røros was one out of 3 finalists nominated in the category Destination Leadership in the National Geographic World Legacy Awards.

Røros is often used for training purposes by other Norwegian and foreign destinations engaged in similar development.

The common strategy and holistic approach towards sustainability that were adopted in 2007 by Destination Røros, the surrounding municipalities and the private business sector, has been the key success factor. Working together instead of competing with each other has resulted in strong international growth and profitable business.

Notably, the personal passion for sustainable tourism development by Sustainable Destination development responsible person, Hilde Bergebakken, has been invaluable for the success. 


\subsubsection{Key Results and Achievements}

\section{Novelty}

Destination Røros is an early adopter of sustainable tourism, and has been involved in setting the course for this holistic thinking in Norwegian tourism. As a national pilot project, Destination Røros helped Innovation Norway to develop a certification scheme for sustainable tourism at the destination level. Innovation Norway has won international recognition for the certification scheme. Røros was among the very first to receive the Sustainable Destination certificate after an overall focus on social, cultural, environmental and financial factors.

Destination Røros has developed its own Certification Program called "Knowledge to be a good host", through which participants become "Certified Hosts". All employees in tourism, commerce and government take a course on local culture and history. This way both the local community as a whole and employees as individuals can take pride in their own history and at the same time be able to inform and educate visitors. Furthermore, employees also undergo training on the other local businesses and learn about the diversity in the region. The target of the training program is to be able to sell each other's products and services, and thereby for example extend the number of guest nights in the region per visitor, ensure that businesses, employees and the local community knows what sustainable tourism is.

In addition to taking the program's courses, each participant has to fill out a given "Copper Card". The Copper Card contains 5 guided tours and attractions the participant has to participate in to become a "Certified Host". The Copper Card is an insurance that all the hosts have first-hand experience of a number of the activities and attractions Røros offers. 150 companies have so far participated in the certification program, educating over 500 employees.

Destination Røros also offers local food courses in order to train local food guides. This has resulted in a local food safari, a bookable product for visitors.

\section{Sustainability Impacts}

Destination Røros offers visitors authentic cultural experiences, which are based on the world heritage, local food culture and many cultural events. The region has two national parks and several protected areas. Active dairy farming can be experienced by visitors along with local food safaris. Among other things, the local food industry has grown from less 
than 30 people to over 100 people working directly with local food production. Røros has been declared Norway's Culture Municipality for three consecutive years, and is often referred to as Norway's local food capital.

Destination Røros and its 180 members have adopted a common sustainability policy. The policy recommends companies to apply for an environmental certification. So far, 10 of the Destination Røros member companies have been certified, and many others have started the certification process. The certified companies represent approximately $60 \%$ of the total sales volume. Of all the member companies, $52 \%$ report having made energy saving measures.

Since the launch of the new strategy in 2007, Destination Røros has managed to turn a deficit into positive numbers. The successful work towards common goals is directly reflected in the member companies' profit margins. Today around 1 million tourists visit the World Heritage mining town Røros annually. Destination Røros is also actively participating in product development, such as local food safaris, which has led to increased value for visitors and businesses alike.

\section{Challenges and potential for further development}

Despite success, Destination Røros is facing difficulties to find sufficient financial resources for sustainability development since the pilot project with Innovation Norway ended.

Another challenge is related to companies who are not members of Destination Røros. Even though over $90 \%$ of the companies of the Røros area are members of Destination Røros, there are still some free riders. Destination Røros has worked on the issue, mainly through emphasizing the importance of cooperation for mutual benefits.

While there is potential for improvement related to the sustainability of transportation to and within the destination, the possibilities of Destination Røros to influence the transportation choices visitors make remains a challenge. 


\subsection{Lofoten Kajakk - certified ecotourism activities}

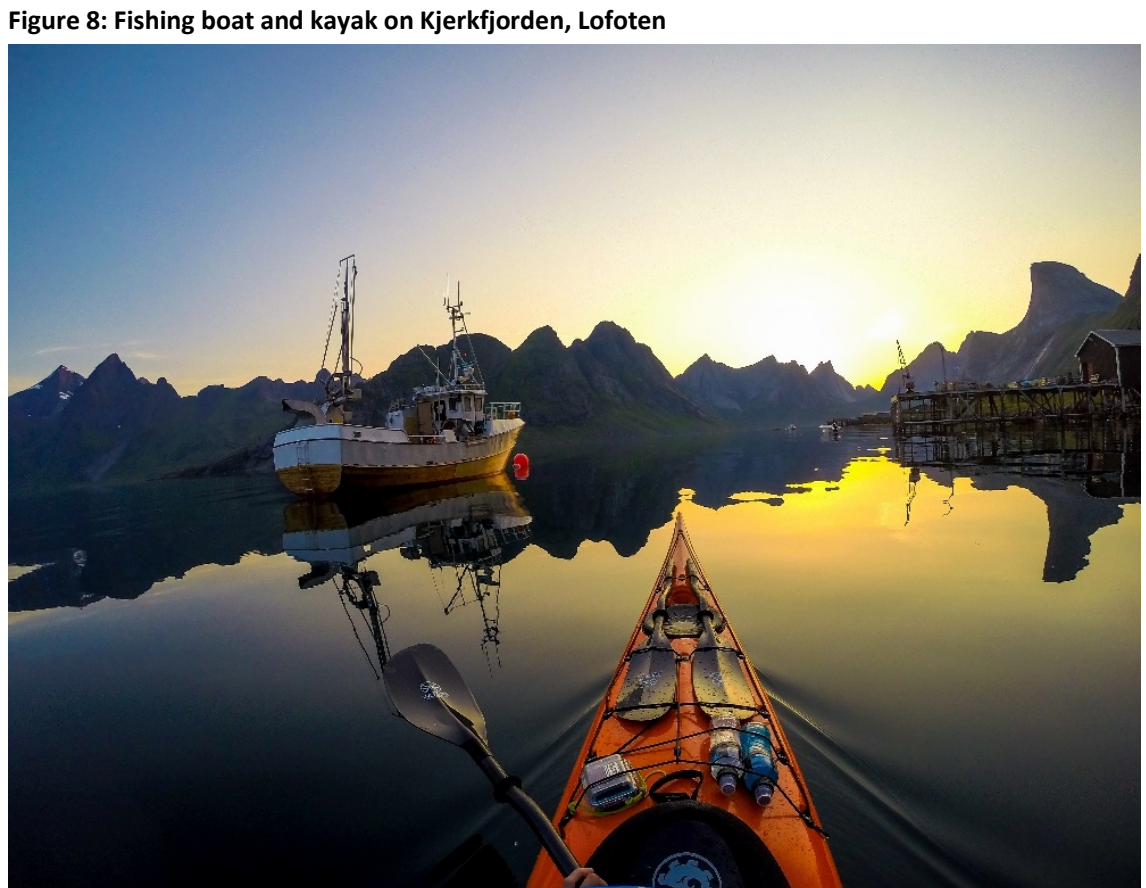

Source: (C) Tomasz Furmanek/Visitnorway.com

\section{Case Description}

Country:

Norway (Region: Europe)

Geographic scope:

Local

Theme:

SPP and Ecolabelling, Tourism

Community:

Sustainable Tourism

Type of Initiative:

Information, awareness-raising, education

Lead actor:

Lofoten Kajakk/Aktiv

Type of lead organization:

Business sector

\section{Budget}

The Eco certificate costs NOK 15,000 per 3 years (appr. EUR 1,600/3 years)

\section{Partners}

The company is partnering with another ecotourism company based in Tromsö. 
Status

Started in 1996. Ongoing.

\section{Next steps}

During spring 2016, Lofoten Kajakk is planning to get the ecotourism certificate also to the limited company Lofoten Aktiv AS, which follows the same sustainability principles as the personal company Lofoten Kajakk established by Jann Engstad.

Contact person for more information

Jann Engstad, post@lofoten-aktiv.no

Note: Case descriptions, e.g. with regards to geographic scope, theme, community, type of initiative, and type of lead organisation, follow the groupings used within UNEP's SCP Clearinghouse.

\subsubsection{Introduction}

Lofoten Kajakk was the first company in Norway to become certified by Norwegian Ecotourism. The company's objective in applying for the ecotourism certificate was to work as a role model in order to avoid detrimental changes in the nature. The ecotourism quality label is valid for three years until the next recertification. For Lofoten Kajakk, acquiring the certificate required changes in the product portfolio as well as improvements to fuel consumption, energy efficiency and energy types used. Lofoten Kajakk offers sea kayaking tours and courses. The company's service products have been developed from a sustainability viewpoint. Lofoten Kajakk's goal is that whilst participating in the activities, their clients will learn new practices on how to minimize their environmental impact.

\subsubsection{Objectives}

The objective of becoming certified as an ecotourism company was to work as a role model in order to avoid detrimental changes in the nature and to educate guests in environmentally sound behavior. 


\subsubsection{Activities}

Lofoten Kajakk is one of the oldest activity companies in Norway and it is owned and operated by its creator Jann Engstad. Since 2008, Lofoten Kajakk have been "Certified Ecotourism Norway". In order to receive the certificate, the company had to meet specified criteria on use of resources, purchasing eco-friendly products and services, energy efficiency and renewable energy, use of chemicals, waste reduction measures, transport methods and make changes to the product portfolio.

The company had to give up motorized whale watching tours in order to receive the certificate. Hence the company's service products have been developed so that only non-motorized activities are offered. The activities include guided sea kayaking, cycling, hiking, snowshoeing and Nordic skiing tours. Lofoten Kajakk's goal is to teach its clients new practices on how to minimize the impact on wildlife for instance by optimal advance planning and environmentally sound behavior in the nature. The guests are for example taught how to attract wildlife without disturbing it. The camping sites are selected according to their ecological carrying capacity. The objective is that during the activities any unnecessary noise is avoided and no trace is left to the nature. Food products are selected and packaged in manner that minimizes waste. The client transport to and from the starting points of the activities is optimized in order to reduce fuel consumption. In line with the certificate, the company is studying the possibilities to purchase an electric or a hybrid minibus. However, suitable options for longer distances and cold conditions do not yet exist. The company's storage building has an energy efficient air heat pump that runs with renewable energy.

In the future, the company wishes to be able to extend the length of the tours from half a day trips to overnight tours in order to minimize the emissions from transportation between accommodation and starting points of tours.

\subsubsection{Success factors}

The most important success factor has been the personal belief of Jann Engstad that ecotourism is the only sustainable business model in the future. In addition, the company's open approach towards cooperation with other companies has been successful. 


\subsubsection{Key Results and Achievements}

\section{Novelty}

Jann Engstad has actively participated in the development of ecotourism in Norway. Lofoten Kajakk was the first company in Norway to become certified by Norwegian Ecotourism.

\section{Sustainability Impacts}

The main sustainability impacts from Lofoten Kajakk's activities stem from the potential behavioral changes of the clients. Lofoten Kajakk collects feedback from the clients about what they have learned about ecological travelling behavior. The most common new skills and behaviors that the clients have learned are:

- It is easy to prepare for a trip in way that helps minimize the amount of waste.

- Buying local food is more interesting and exiting.

- It is both possible and more fruitful to approach wildlife in their terms.

In addition, the decision to give up motorized activities, such as whale watching tours, has resulted in nearly 10,000 liters annual fuel reduction, in addition to noise minimization. The company has also reduced land transport fuel consumption by $30 \%$, (some 250 liters) through optimizing the transportation between the guest accommodation and the tour starting points.

The company has been recognized for its efforts towards sustainable tourism. Lofoten Kajakk was awarded WWF (World Wildlife Foundation) first prize in 1998 and was "1st Runner-up" in 1999 for purposeful work and inspiring participation in "Linking Tourism and Conservation in the Arctic" - project of WWF.

\section{Challenges and potential for further development}

The biggest challenge is the lack of overall recognition towards ecotourism. The government has stopped supporting the Norwegian Ecotourism and therefore it is not sufficiently well known by the consumers or service providers. Other companies in the area have shown little interest towards ecotourism development. In addition, the lack of European wide ecotourism certificate with corresponding criteria is complicating the comparability of ecotourism companies in different countries and hindering the awareness of ecotourism among consumers. 


\section{Sweden}

\subsection{Wild Sweden}

Figure 9: Wild Sweden organises trips to the Nordic wilderness

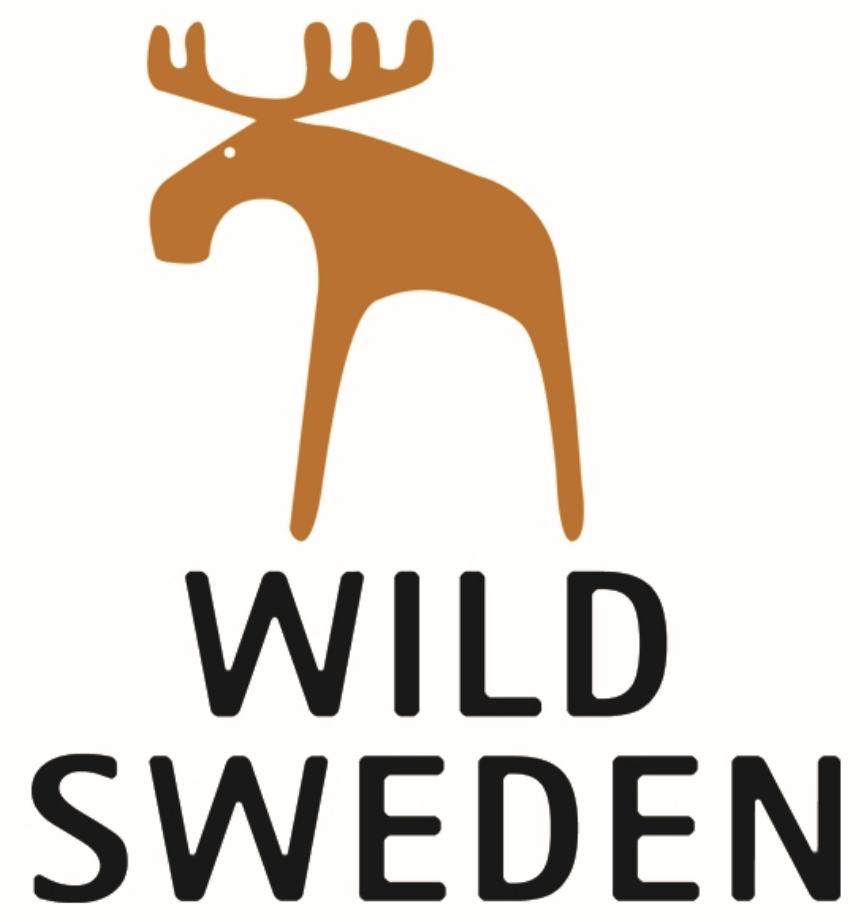

\section{Case Description}

Country:

Geographic scope:

Theme:

Community:

Type of Initiative:

Lead actor:

Type of lead organization:
Sweden (Region: Europe)

National

Tourism, Sustainable Rural Development

Sustainable Tourism

Information, awareness-raising, education

Skogens Konung AB/Wild Sweden

Business sector 


\section{Budget}

The company turnover in 2015 was ca EUR 310,000 EUR, and it has been steadily growing each year.

\section{Partners}

Wild Sweden works together with guesthouses, hotels and lodges that are locally owned, usually family-run, and mostly small-scale. They collaborate with local taxi and train companies to provide transport for their clients. They also cooperate with supermarkets and restaurants. Partners are chosen so that they serve meals with a local touch, with as much locally produced and/or organic ingredients as possible.

Wild Sweden is a member of the Swedish Ecotourism Society and three regional tourism boards, namely VisitVästmanland (VKL), Visit Södra Dalarna, and Siljan Turism. Through the regional tourism boards Wild Sweden receives invitations to seminars and activities arranged by VisitSweden.

Status

Started in 2003. Ongoing.

\section{Next steps}

Wild Sweden is planning to begin to offer more long multi-day trips and probably less of the short day-trips. This way they will be able to sell more entire holiday experiences rather that providing just glimpses into nature. Expanding the tours to the arctic areas of Sweden is also a goal for the near future.

Contact person for more information

Marcus Eldh,marcus@wildsweden.com

Note: Case descriptions, e.g. with regards to geographic scope, theme, community, type of initiative, and type of lead organisation, follow the groupings used within UNEP's SCP Clearinghouse.

\subsubsection{Introduction}

Wild Sweden is an awarded ecotourism company that has worked for more than 10 years and with guests from more than 75 countries around the world. Wild Sweden aims to offer genuine nature experiences that support both wildlife conservation and sustainable local economic development. Wild Sweden takes its customers to see moose, wolves, brown bears, beavers, and wolverines in the Swedish wilderness. Wild Sweden's 
tours range from 5-hour excursions to 8-day trips and include accommodation, food, and transport. Wild Sweden works to sustain the environment and to show that wild animals are most valuable to societies when alive and in their natural habitats.

\subsubsection{Objectives}

Wild Sweden's objective is that their guests return home with more knowledge about and respect for wild animals and nature.

\subsubsection{Activities}

Wild Sweden only uses local guides in order to take their customers to the best places for experiencing wildlife up close. The guides are nature experts, who explain the ecosystem and human-wildlife-interaction to their customers. About $50 \%$ of the customers are very interested in and knowledgeable about nature, but not necessarily so about the Swedish wilderness. The other half of the clients are urban people who are initiated to, and get their first glimpse of, wild nature through Wild Sweden.

Wild Sweden cooperates with small, family-run guesthouses in rural areas to support local jobs and provide an authentic atmosphere. Guests are treated with locally produced food, often utilizing wild hunted meat such as wild boar and moose, and other forest bounty such as wild berries and mushrooms.

Wild Sweden has a policy to reuse and recycle whenever possible, which includes separating and recycling all waste. The boats are equipped with electric motors and hydropower is used to recharge the batteries. While using a minibus to access tour locations, driving is minimised and carbon emissions produced by Wild Sweden are offset through MyClimate.org, by supporting projects that reduce greenhouse gases directly.

Wild Sweden also helps to develop and promote new eco-tourism projects and companies in the whole of Sweden. Wild Sweden has held more than 100 lectures and workshops across Sweden as well as in Norway. The reason for holding these lectures is that in Wild Sweden's opinion, ecotourism should grow not through significant growth of their own business but through replication and numerous new sustainable excursion businesses scattered around Sweden and beyond. Of course, this will mean more competition for Wild Sweden, but also more colleagues and more wildlife experiences, without straining single excursion sites too much. 
Wild Sweden tracks and monitors several wolf packs in the Bergslagen forests. Since 2006 they have provided data for the Scandinavian Wolf project that aims to monitor and learn more about the wolf population.

\subsubsection{Success factors}

One of Wild Sweden's main success factors is that they offer sustainable nature excursions, with unique wilderness experience and wild animals in their own habitats. It is also one of the focus points in their marketing.

Three other factors in the operation of Wild Sweden have been central to the success so far. First, Wild Sweden sells complete packages to their customers. This means that Wild Sweden is not selling only the nature activity but also the accommodation, transport and food the customers need. Second, Wild Sweden sells very specific and detailed packages, telling exactly what is included and what the customers get. Third, to reach many different people, Wild Sweden uses multi-channel distribution in its marketing. Wild Sweden sells tours to travel agencies around the world. Only about $50 \%$ of the tours are booked via their own website. Half of the tours are sold through third parties, including travel agencies in other countries.

\subsubsection{Key Results and Achievements}

Wild Sweden's approach has gained them several awards. The awards also give customers high expectations, so Wild Sweden has to develop constantly in order to keep their customers satisfied. Wild Sweden has gained the following awards:

- Swedish tourism award "Stora Turismpriset", 2015.

- 50 Tours of a Lifetime, National Geographic, 2015.

- Swedish Rural Development Project of the year, for the development process “Ekoturism i praktiken”, 2010.

- Grand Travel Award, Ecotourism company of the year in Sweden, 2009.

- Nature's Best, the quality label for ecotourism, approved by the Swedish Ecotourism Society, since 2005. 
For being such a small company, Wild Sweden gets a lot of attention from magazines and websites from around the world. Social media is key in the business development: people want to share their experiences and through that, Wild Sweden gets publicity. Additionally, Visit Sweden and the travel agencies they cooperate with sometimes are contacted by a journalist interested in writing a story.

\section{Sustainability Impacts}

Wild Sweden attempts to minimise its carbon dioxide emissions, and offsets the remaining impacts. Also recycling of waste and limited amount of tours helps to protect the environment. By employing local guides, Wild Sweden has impact on local economy as well. Raising people's awareness of nature and wildlife may have a great positive impact through behaviour change.

\section{Challenges and potential for further development}

One lesson learned very early was that most of the clients are not Swedish, and that the biggest potential lies abroad. This is also why the main language of the webpage is English.

Another lesson learned is that it is good to know the other local tourism companies and meet with them, even though they might be competitors, since it provides opportunities to learn from each other. The best input does not necessarily come from the closest neighbour, but similar businesses abroad. Local, regional and national tourist boards are a good way to contact other local businesses. 


\subsection{Sustainable Destination Development}

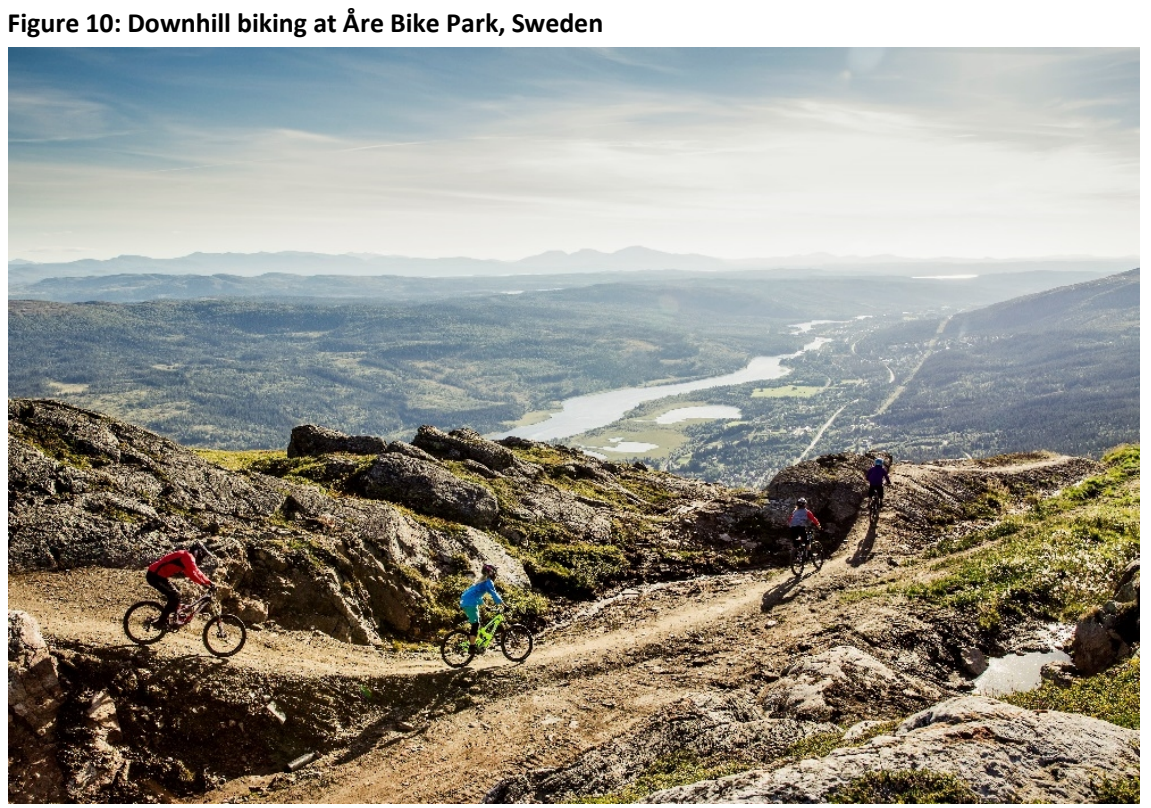

Source: (C) SkiStar AB/Jonas Kullman.

\section{Case Description}

$\begin{array}{ll}\text { Country: } & \text { Sweden (Region: Europe) } \\ \text { Geographic scope: } & \text { National } \\ \text { Theme: } & \text { Tourism } \\ \text { Community: } & \text { Sustainable Tourism } \\ \text { Type of Initiative: } & \text { Production and value-chain management } \\ \text { Lead actor: } & \text { The Swedish Agency for Economic and Re- } \\ & \text { gional Growth (Tillväxtverket) } \\ \text { Type of lead organization: } & \text { Partnership/network/consortium, Public } \\ & \text { institution, Business sector }\end{array}$

\section{Budget}

The total budget for the development project was ca EUR 6.4 million, with ca EUR 1 million allocated for each of the five destinations and with ca EUR 1 million allocated to common project development activities, including joint measures to improve overall sustainability. The participating destinations had 
to match the ca EUR 1 million received with the same amount of co-financing. The participating destinations contributed to the co-financing in varying manners, e.g. with some of the destinations also including private co-finance (e.g. from participating companies) in the total budget required.

\section{Partners}

The project was initiated and coordinated by the Swedish Agency for Economic and Regional Growth (Tillväxtverket) through the mandate and resources given to by the Swedish Government. VisitSweden (also being member of the steering group) that has the mandate to market Sweden on international markets, contributed to the project through its knowhow and competence in international markets and market demand. The project also established collaboration with academia, in particular with Linköping University (Centrum för kommunstrategiska studier CKS, at Linköping University). In addition, the five destinations have established their respective partnerships on local and regional levels, in support of their specific project objectives.

\section{Status}

Started in 2012, ended in 2015.

\section{Next steps}

All destinations have noted their interest and commitment to continue with their sustainable destination development activities after the official project closure in end 2015. The scope and extent of activities on national level and the five destinations varies and will evolve in 2016.

VisitSweden has estimated that some 28 million Europeans and Americans will travel to Sweden in the next three years, and the industry has set a goal of doubling the value of Swedish tourism services and products by 2020. The Swedish Agency for Economic and Regional Growth (Tillväxtverket) continues also working on sustainable destination development and launched new calls in early 2016 with this goal in mind.

\section{Contact person for more information}

Christina Rådelius, christina.radelius@tillvaxtverket.se

Note: Case descriptions, e.g. with regards to geographic scope, theme, community, type of initiative, and type of lead organisation, follow the groupings used within UNEP's SCP Clearinghouse. 


\subsubsection{Introduction}

The Sustainable Destination Development initiative was a development project with the overall goal to strengthen and develop sustainable tourism destinations in Sweden over a four-year period. Five destinations with varying character (Bohuslän, Kiruna, Stockholm archipelago, Vimmerby and Åre) were chosen.

During 2012-2015 the destinations initiated a number of activities in order to prolong the tourist season, improve the quality in hosting, develop new and more sustainable products and services, enhance overall accessibility, and generally improve the destinations quality and competitiveness. The objective was to attract more international visitors whilst holistically respecting sustainability aspects.

The project was guided by a steering group consisting of the Swedish Agency for Economic and Regional Growth (Tillväxtverket) as well as VisitSweden, with the integral view to draw on lessons learned and share best practices by participating destinations and more broadly in Sweden.

\subsubsection{Objectives}

The Sustainable Destination Development initiative was a development project with the overall goal to strengthen and develop sustainable tourism destinations in Sweden over a four-year period (2012-2015). Bohuslän, Kiruna, Stockholm archipelago, Vimmerby and Åre were chosen to participate in the project. The objective was to improve their organisational structures and to engage the private sector in quality and sustainability improvements for sustainable destination development.

During 2012-2015 the destinations initiated a number of activities in order to prolong the tourist season, improve the quality of hosting tourists, develop new and more sustainable products and services as well as improve overall accessibility (considering the full accessibility chain from information of destination in various media, transport options, signalling at destination in multiple languages etc.). The overall goal was to improve the quality and competitiveness of the destinations with the objective to attract a higher number of international visitors while respecting the sustainability aspects in a holistic manner.

The project was guided by a national steering group consisting of the Swedish Agency for Economic and Regional Growth (Tillväxtverket) and VisitSweden. The project also included an integrated research and academia collaboration aspect, with the integral objective to learn and share best practices between the participating destinations and more broadly in Sweden. Hence, the project concept embraced an approach starting 
from an analysis of "WHAT" (including the status, capacities, challenges and resources). This analysis of the framework conditions and resources at the respective destinations eventually led to a better understanding of "HOW", i.e. how to make sustainable destination development possible and a reality on the ground.

\subsubsection{Activities}

The project covered a wide spectrum of activities, which varied depending on the particular needs, evaluation phase and characteristics of the respective destination. However, several common features in the measures taken across the five destinations can be identified in the areas of:

- Development of market demand knowledge and understanding of the international target groups.

- Innovation and product development.

- Business development, with a view on private tourists as well as B2B.

- Sustainability and quality development measures.

- Communication and trade market platform development and application.

- Knowledge and competence development measures.

- Organisational development and building of partnerships.

- Enhancement of service culture and capacity, hosting knowledge and readiness.

- Development of accessibility aspects at destinations, including infrastructure development, signalling, guidance etc.

- Areal/city planning and land use planning with a view to support holistic destination development.

In addition to these measures, generally recognized and broadly embraced at the five destinations, the following key activities were specifically highlighted at the respective destinations:

\section{Bohuslän}

- Preparing a joint declaration/statement of commitment by key stakeholders.

- Outlining a plan for implementation and identifying and confirming key roles, responsibilities for participating stakeholders, including commune, companies, local/regional tourist organisations. 
- Active sharing of know-how, transmission of lessons learned through seminars and training.

- Product and service development and sustainable development based on the Swedish Welcome program.

- Joint trademark development for Bohuslän, establishing a "trademark platform for Bohuslän".

\section{Kiruna}

- Development of Kiruna Lapland's sustainability program based on the Global Sustainable Tourism Councils (GSTC) destination criteria and creating a monitoring system.

- Development of a comprehensive chain for accessibility and infrastructure (from finding the destination on the internet, making the booking, transport, clear signaling in all needed languages etc.).

- Putting special focus on space science and space tourism.

- Close collaboration with academia/research to secure high level of know-how and learning, with student traineeships, and collaboration between academia and companies on tourism.

- Identifying and outlining longer-term financing options for tourism development.

\section{Stockholm archipelago}

- Establishment of a commitment and collaboration framework for longer term action between seven municipalities with clearly defined steering- and working groups.

- Establishment of a joint communication platform and website and working for a "joint/shared destination identity".

- Concrete actions for destination development with the development of 33 new destination products.

- Development of a joint sustainability strategy with concrete measures for improved sustainability, based on the program Swedish Welcome.

- Innovation work to help join northern and southern actors within the Stockholm archipelago. 


\section{Vimmerby}

- Expanding product and service deliveries in the "gardens of Astrid Lindgren".

- Developing further the tourism business services further with companies.

- Development of high quality products and services.

- Outlining a sustainability approach through the sustainability program Swedish Welcome, with the view to enhance and certify sustainability of companies.

- Training and development of knowledge and skills in being a good host.

Åre

- Working holistically on a more sustainable Åre covering economic, social and ecological sustainability aspects. Åre worked on sustainability aspects along the Global Sustainable Tourism Council destination criteria (GSTC-D) and Natural Step's principles for sustainability.

- Identification and development of new products and travel services.

- Increase global awareness about Åre.

- Identify competence gaps and fill them.

- Secure long-term financing for Åre destination development.

\subsubsection{Success factors}

A number of common factors contributing to successful implementation of project activities, and attainment of project objectives, can be identified across the five destinations, including:

- All key stakeholders are aware of and agree on the key features of the destination and the value ("value chain") proposition it can make to international tourists.

- Methods and tools for improving the quality and sustainability of destinations become operational and effective only once their role in the overall context is well understood.

- It is important to be clear in communication, and have a joint "language/terminology" to allow efficient learning and sharing of lessons learned.

- It is particularly important for decision makers, politicians to understand the context well and see the "whole picture" in order to 
support efficient and effective implementation through their decision making.

- The developers need to be given a clear mandate, resources as well as appropriate tools.

- The stakeholders, that put things concretely into movement, need to be given resources, knowledge and a supportive framework/cluster for implementing the quality and sustainability improvements in practice.

The respective five destinations, in addition, point out the following destination specific key factors, for overall success in their work:

\section{Bohuslän}

- Strong support and commitment from local political leadership, including opposition.

- Strong prioritisation and focus on collaboration with companies that have the potential and interest to reach international markets/clients as well as focus on products/services for which there has been identified and confirmed demand.

- Access to tools and business model support.

\section{Kiruna}

- Solid networks and good relationships (locally, regionally as well as nationally).

- Access to expert knowledge (including research and academia).

- Solid analysis backing the chosen measures with clear share of responsibilities (including results monitoring and active involvement/participation of key stakeholders).

\section{Stockholm archipelago}

- A strong, joint steering group coordinating a considerable number of stakeholders.

- Clear guiding documents (strategic, project plan, activities and budget) helping to build the mandates for action.

- Successful collaboration across different levels and actors (identifying early on key persons and driving actors, building confidence and trust for joint action). 


\section{Vimmerby}

- Making clear choices early on and prioritising, hence creating focus and momentum.

- Create a joint vision (covering also the longer-term) that lays the basis for true collaboration between actors and engage persons that can act as drivers and lighthouses.

- Training activities supporting the implementation.

Åre

- A solid organizational platform with strong private sector engagement and mandate to act.

- A clear mandate to identify destination specific strengths internationally, prioritize courageously and work to further strengthen those strengths.

- A strong commitment and spirit to continually improve and do better also with a longer term vision in mind.

\subsubsection{Key Results and Achievements}

\section{Novelty}

The project has been innovative in pioneering work on destination level, helping to establish commitment and collaboration (including new forms of collaboration) between a considerable number of stakeholders, on local, regional and national - as well as across various sectors and organizations.

At the same time, e.g. in the case of Kiruna, the destination development has had to address the whole new concept of a "moving city" as the destination development is part of an on-going process to physically move the city center due to mining activities. This project has obviously highlighted the critical importance to also integrate land-use planning aspects (and stakeholders) into all destination development measures.

Also the aspect of integrating cultural and historical values, e.g. through pioneering (formal) collaboration agreements with Sami people in Northern Sweden, as part of joint destination development, can be considered innovative and a case for learning and replication for other destinations with similar surroundings.

In the case of Åre, having a vision by 2020 to become Europe's most attractive alpine year-around destination, has widely broadened the field and actors as well as necessary measures required for destination development, and hence forced to innovation for year-round destination development (from traditional winter tourist destination). 


\section{Sustainability Impacts}

By the end 2015, the project had achieved among other the following results:

- More new products (circa 150 new products) available for the international market.

- More in-depth knowledge and understanding on the international market demand.

- More collaboration arrangements with international tourism actors, travel agencies.

- Increased visibility and articles in international media about the destinations.

- Increased number of visitors during the summer of 2015 at the five destinations.

As part of the monitoring, and supporting the learning process, Tillväxtanalys (Growth Analysis - Swedish Agency for Growth Policy Analysis) produced annual reports on various aspects of the development project covering among the preconditions, program logic, implementation aspects and results of the project. A common challenge in the monitoring and evaluation framework has been in establishing suitable baselines (to allow quantitative assessment of results based on various indicators) as well as the overall challenge of attribution/contribution, i.e. a considerable number of other external factors have influenced the results above.

With regards to sustainability work (in particular the environmental sustainability) progress has been achieved, through the application of two approaches. Three of the destinations, including Bohuslän, Vimmerby and Stockholm archipelago, chose to work with the Swedish Welcome approach, with a certification scheme of its own for companies. Åre and Kiruna advanced on sustainability matters relying on the sustainability criteria of Global Sustainable Tourism Council.

\section{Challenges and potential for further development}

The project has been helpful in creating a stronger understanding of the approaches needed as well as challenges that have to be encountered when developing sustainable destinations (not actually "owned" by any single actor) - in comparison to doing marketing and promotional measures only for/by separate actors and businesses in tourism destinations.

The project has also highlighted the benefits of having a national initiative that can serve as an umbrella for concrete action, also serving to 
encourage, give credibility and status as well help drive concrete action on destination levels. The project also highlights important benefits of bundling several destinations in such collaboration, allowing learning from each other and sharing challenges as well as solutions with peers.

The project stakeholders note the need to ensure that relevant expertise and competence is available, or will be created/developed (e.g. in collaboration with relevant schools and universities) and made available for destination development - which is different from more "traditional" marketing and promotional efforts by various single actors. Hence, one of the key lessons learned from this project, is to understand the importance of coordination, clear communication, mandates and share of responsibilities to which actors truly commit to, noting the considerable amount of stakeholders involved in destination development. Also, the financial viability, and ensuring financing for development activities for a longer-term is a common challenge that all destinations recognize, and to be addressed as a cross-cutting theme in all sustainable destination development.

And finally, the project highlights the importance to note that destination development is integrally sustainable development of the respective destinations, in order to be viable and sustainable communities on their own, not only for the sake of international tourism, but holistically for all people living in and/or visiting the community for shorter periods of time. 

Consumer Information 



\section{Denmark}

\subsection{Pregnant? Know your chemicals}



Source: (c) Danish Environmental Protection Agency.

\section{Case Description}

Country:

Denmark (Region: Europe)

Geographic scope:

National

Theme:

Sustainable Lifestyles and Consumption, Awareness-raising and Education for SCP, Health and Social Services 


$\begin{array}{ll}\text { Community: } & \begin{array}{l}\text { Sustainable Lifestyles and Education, } \\ \text { Consumer Information, Sustainable Food } \\ \text { Systems }\end{array} \\ & \text { Information, awareness-raising, education } \\ \text { Type of Initiative: } & \text { Danish Environmental Protection Agency } \\ \text { Lead actor: } & \text { Government }\end{array}$

\section{Budget}

The project has operated with a budget of approximately EUR 100,000 for external consultants. The project has benefited from in-kind input by the Danish Environmental Protection Agency (EPA), where the work hours used by the Danish EPA are not included in this budget.

\section{Partners}

The recommendations have been made by the Danish Environmental Protection Agency in collaboration with advice from the Danish Veterinary and Food administration, Danish Health Authority and the Danish Working Environment Authority.

Status

Started in 2015. Ongoing.

\section{Next steps}

The campaign will continue and the materials will also continue be distributed to women through doctors.

Contact person for more information

Shima Dobel, sdo@mst.dk

Note: Case descriptions, e.g. with regards to geographic scope, theme, community, type of initiative, and type of lead organisation, follow the groupings used within UNEP's SCP Clearinghouse.

\subsubsection{Introduction}

The campaign "Pregnant? Know your chemicals" is a national information campaign coordinated by the Danish Environmental Protection Agency. The objective is to give the public easy access to impartial information on chemicals to be avoided. The campaign provides advice to pregnant 
women and women planning a pregnancy, by providing easily accessible information about everyday chemicals. The purpose is not to scare women, but to offer information that enables active choices in respect to chemical exposure. The campaign is focused on seven key recommendations for daily life. The recommendations cover food, alcohol, tobacco, medicines and use of everyday chemicals i.e. paints, cleaning products and cosmetics. The information is provided through multiple channels and includes a brochure, Facebook page and other social media channels as well as a web page that presents more in-depth information on chemical exposure and on how to avoid the most harmful substances.

\subsubsection{Objectives}

The purpose of the campaign is to provide advice to pregnant women and women planning a pregnancy, through easily accessible information dealing with everyday chemicals. The purpose is not to scare women but to offer information that enables active choices regarding chemical exposure.

\subsubsection{Activities}

The campaign "Pregnant? Know your chemicals" was launched in 2015 and is still ongoing. It is based on a previous campaign from 2012. The campaign from 2012 was based on a report that identified the combined exposure and risk of specific endocrine disrupting substances. The first campaign with advice on chemicals for pregnant women from the Danish EPA was conducted already in 2006. The target group for the campaign is women in the age group 18-45 that are pregnant or planning a pregnancy.

The seven main recommendations and key messages of the campaign are:

- Stop smoking and avoid smoke from others. Avoid smoke and ask others to put out their cigarette or smoke outside.

- Don't drink alcohol if you are pregnant. If you are trying to get pregnant, avoid alcohol to be on the safe side.

- Clean and dust your home once a week, and air-out thoroughly twice a day.

- Buy products with official recognized ecolabels (the Nordic Swan ecolabel and/or the EU-Flower ecolabel) - preferably without perfume. 
- Limit your contact with chemicals such as cleaning agents, paint, aerosols and hair dyes.

- Vary your diet and eat many different types of food every day. Follow the recommendations from the Danish Health and Medicines Authority and the Danish Veterinary and Food Administration on dietary supplements for pregnant women.

- Only use medicine prescribed after consulting your doctor. This also applies for pain relievers and natural or herbal medicines.

The most recent campaign started in February 2015. The campaign includes a homepage and a folder with specific information on pregnancy, children and family life as well as printed materials in magazines and local papers. The folder with information is distributed to pregnant women during visits at the midwife or doctor's office.

The Danish Environmental Protection Agency homepage and Facebook page on "Everyday chemicals" provides in-depth information and brings under one umbrella information on exposure of chemicals from every day products and common products at the workplace. The main channels used in the campaign include the internet (including banners), Facebook and Instagram as well as blogs.

\subsubsection{Success factors}

It is important to reach women in early stages of the pregnancy or when pregnancy is planned. The most effective way to reach them appears to be in connection with the first visit to the doctor at the onset of the pregnancy.

\subsubsection{Key Results and Achievements}

\section{Novelty}

Information on the risks related to alcohol, smoking and some food items has been available for years. The campaign has an element of novelty because it also provides information on substances, which may be harmful for the endocrine system. The campaign presents information that makes it possible for women to make their own choices and, hence, can help avoid most chemical related risks during a time when it matters the most and when women are very receptive to the information. 


\section{Sustainability Impacts}

A survey-based evaluation of the campaign was made in 2015. About $25 \%$ of the target group remember seeing the campaign. Banners on social media and in the information folder have been the most efficient ways to reach the target group. The campaign has had a positive effect on the target group. About $86 \%$ have learned something new and useful on how to avoid harmful chemicals during pregnancy through the campaign. Only $9 \%$ mention that they have not received useful information or feel that it has not been relevant for them. However, despite being well received, the campaign did not seem to have had a significant impact on behavior. This can most likely be attributed to the fact that most respondents seemed to be well aware of most recommendations and have followed them even before coming into contact with the campaign.

\section{Challenges and potential for further development}

One challenge in this initiative has been to ensure that the information also reaches less aware and less informed women. This target group could for instance include migrants that have fairly recently moved to Denmark and who may not have the same level of general knowledge of health and pregnancy related issues as the rest of the population. Some people outside the larger cities may also have less knowledge or less interest in chemical related information. The evaluation recommended that the next campaign could focus more on other recommendations than to avoid smoking and alcohol, because the awareness of these particular risks is already high.

\subsection{The Organic Cuisine label}

Figure 12: The Organic Cuisine Label is a certification scheme for restaurants and catering businesses showing the percentage of organic produce used.

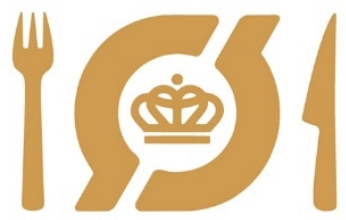

90-100\% økologi

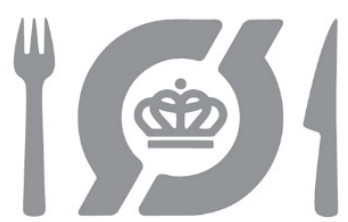

$60-90 \%$ økologi

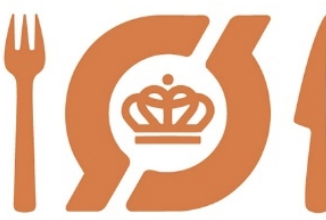

$30-60 \%$ økologi 


\section{Case Description}

Country: Denmark (Region: Europe)

Geographic scope: National

Theme:

SPP and Ecolabelling, Sustainable Food Systems, Sustainable Lifestyles and Consumption, Sustainable Production and Value Chains, Sustainable Public Procurement, Awareness-raising and Education for SCP, Agri-food

Communities: $\quad$ Consumer Information, Sustainable Food Systems, Sustainable Public Procurement, Sustainable and Safer Production, Sustainable Tourism, SCP Europe

Type of Initiative: Information, awareness-raising, education

Lead actor: Danish Veterinary and Food Administration (Ministry of Environment and Food)

Type of lead organization: Government

\section{Budget}

The overall average annual budget for marketing and promotion activities and advisory services is difficult to calculate and distinguish from related activities but estimated at about EUR 150,000-200,000. This does not include the costs for certifying the produce, the internal development work required to certify the establishment or the site inspections carried out by the Danish Veterinary and Food Administration.

\section{Partners}

Danish Veterinary and Food Administration in collaboration with Organic Denmark.

\section{Status}

Started in 2009. Ongoing.

\section{Next steps}

The next steps are to focus efforts on the private sector and especially the HORECA-segment. 
Contact person for more information

- Gregers Hummelmose, Danish Veterinary and Food Administration, gdhu@fvst.dk

- Rikke Groenning, Organic Denmark, rtg@okologi.dk

Note: Case descriptions, e.g. with regards to geographic scope, theme, community, type of initiative, and type of lead organisation, follow the groupings used within UNEP's SCP Clearinghouse.

\subsubsection{Introduction}

The Organic Cuisine Label is a certification scheme for restaurants and catering businesses showing the percentage of organic produce used. The label was introduced in 2009 and is government controlled and free for the users. The label provides information to both customers and personnel and promotes the use of organic food. The label has three levels representing the proportion of organic ingredients used: bronze, silver and gold. In May 2016, almost 1,700 professional kitchens use the label and the number has grown by more than $50 \%$ in both 2014 and 2015. Also, the market for organic food service has almost tripled since 2009 reaching ca EUR 175 million in 2014. The Organic Cuisine Label is managed and controlled by the Danish Veterinary and Food Administration and promoted in collaboration with Organic Denmark.

\subsubsection{Objectives}

The Organic Cuisine Label was created to encourage the use of organic produce for preparation of organic food in large-scale kitchens, i.e. in restaurants, work canteens and other institutions such as hospitals or schools. The label provides the customer with easy to recognize, consistent guidance on where they can eat organic food. As the label has three levels, it also promotes increasing the use of organic produce by giving incentives to the establishment to "go for gold", i.e. serving $90-100 \%$ organic food. 


\subsubsection{Activities}

\section{The certificate}

The certification has three levels of certification that represent the proportion of organic produce that is used:

- The Organic Cuisine gold label: between 90 to $100 \%$ of all raw materials used are organic. It also requires a written food policy, which has to be visibly displayed to customers.

- The Organic Cuisine silver label: between 60 to $90 \%$ of all raw materials used are organic.

- The Organic Cuisine bronze label: between 30 to $60 \%$ of all raw materials used are organic.

\section{Licensing}

Restaurants and caterers awarded the Organic Cuisine Label are monitored by the Danish Veterinary and Food Administration. This is done through annual inspections and audits of purchase records. At least once every three months the restaurant must submit a record to the organic control body of all raw materials and produce purchased. The records must show that the establishment in question has purchased on average the proportion organic produce specified in the Organic Cuisine Label over the three-month period. All receipts should state whether the produce is organic or not and must be made available for inspection. The personnel must also be able to prove how the calculations of the proportion of organic produce were made. The organic label certification is carried out by government inspectors for free, which means that the costs of obtaining the label are fully carried by the Danish taxpayers. The inspection is carried out in conjunction with the legally required hygiene inspections, greatly reducing the inspection costs.

\section{Marketing and communication initiatives}

The concept relies heavily on a website that provides extensive information and guidance for restaurants that wish to become certified. A video tutorial explains in practical terms what to do. The Danish Veterinary and Food Administration also offers the possibility of direct advice by mail or phone.

The concept is marketed through seminars, newspapers, magazine articles, awareness campaigns and social media. A main marketing channel 
is peer-to-peer marketing. As the number of labelled restaurants and canteens has increased, this serves to motivate others and accelerates the transition to use organic produce.

Some meetings are arranged to make it possible for personnel from larger kitchens to exchange experiences and best practices. These serve the purpose of spreading information on experiences e.g. how to buy organic produce or to prepare food from scratch instead of from processed intermediate products. Kitchens are also provided recipes on how to prepare food from organic produce.

\subsubsection{Success factors}

The success of the labeling scheme is dependent on the use of the already well-known Danish Organic label, which is one of brands with the highest recognition in Denmark. The label is associated with independent government controls, which increases trustworthiness. Trustworthiness means non-corruptibility, good controls at licensing and follow-up after licensing. A key element in the success is governmental support.

\subsubsection{Key Results and Achievements}

\section{Novelty}

For restaurants and catering service providers, it has been difficult to ensure that all raw materials and other ingredients are $100 \%$ organically sourced. This is the reason why in 2009 the Ministry of Food, Agriculture and Fisheries in Denmark introduced the Organic Cuisine Label in gold, silver and bronze. Before the label was introduced, the establishments could claim to serve organic products, but could not easily provide systematic and reliable proof of it to customers. Today they can advertise their commitment to use organic foods with an official, trusted sign.

\section{Sustainability Impacts}

Using organic labelled products is a convenient way to support the transition of production to more ecologically sound practices and to make an investment in the environment and animal wellbeing. The Organic Cuisine Label is one way of promoting organic food.

In May 2016, there were almost 1,700 issued licenses. The research company YouGov evaluated in December 2015 how well the Danes know different types of organic labels. $47 \%$ of the population knows the Organic Cuisine Label, while the Danish organic label used in retail had recogni- 
tion of $100 \%$ among the population. Overall, approximately $70 \%$ of all Organic Cuisine Labels are found in public kitchens. Approximately $50 \%$ of all labels are registered in the bronze category, 35\% in the silver category and $15 \%$ in the gold category, a distribution that seems to be more or less unchanged as the number of labels increases. Danish people are today especially interested in being able to choose Organic Cuisine products in kindergartens, schools and hospitals.

Efforts to promote the use of organic food in public kitchens have been shown to have several positive side effects, e.g. a potential for significant reduction in food waste and greater focus on healthier and more sustainable menus with more fruits and vegetables and less meat. Some additional impacts of the adoption of the label and the transition to organic produce have been a higher customer satisfaction because of the higher quality of the food. Additionally, a higher personnel satisfaction has been measured, since the personnel has higher work motivation when using better quality produce and fewer processed foods - despite the fact that in some cases the food can be more cumbersome to produce. In some cases, kitchen employees have also had to learn new methods of cooking and recipes to accommodate organic produce and seasonal thinking. This has increased work satisfaction and professional pride.

\section{Challenges and potential for further development}

One important lesson learned is that manager commitment in large establishments and government commitment is essential for promoting the transition to organic produce. Kitchen personnel can be motivated to use organic produce, but without leadership commitment for making the transition within the given budget, concrete steps may not be taken.

The transition to organic produce has been greatly accelerated by government commitment to use $60 \%$ organic produce in government owned establishments, schools, hospitals etc.

As the number of establishments with the label increases this serves to accelerate the transition because of peer-to-peer marketing of the concept. 


\section{Finland}

\subsection{WWF Fish campaign}

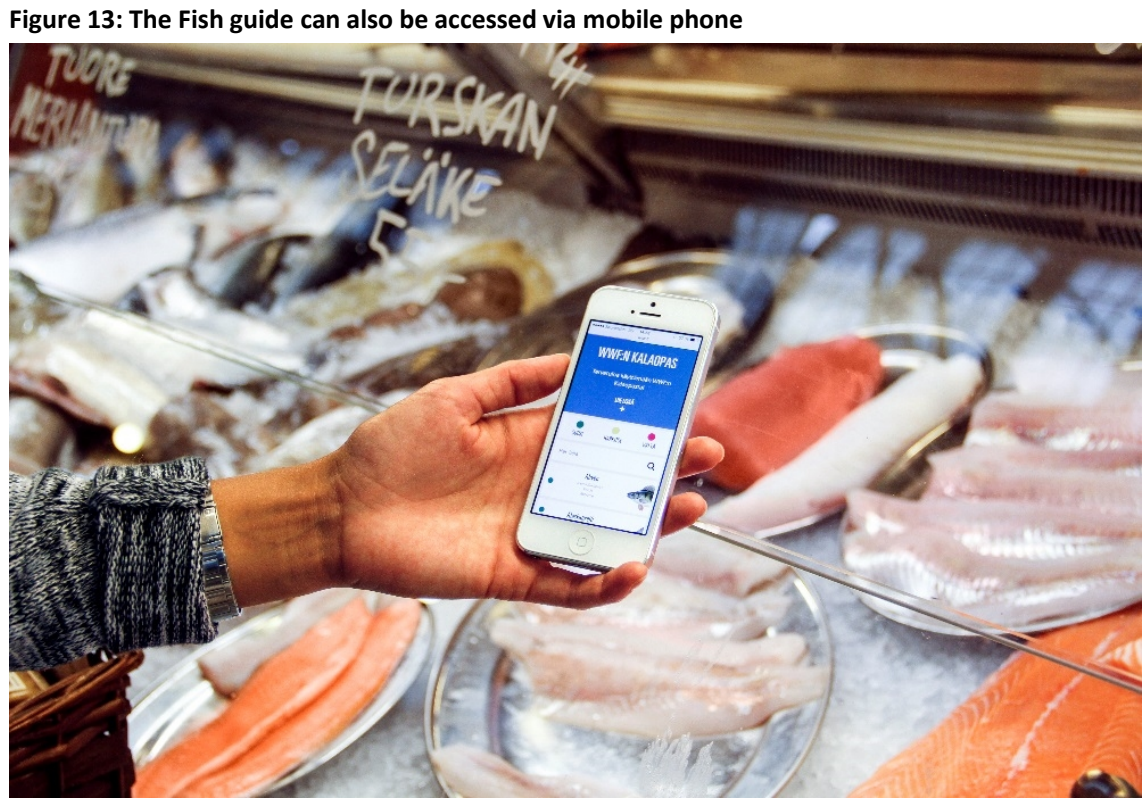

Source: (C) Joonas Fritze/WWF

\section{Case Description}

Country:

Geographic scope:

Theme:

Community:
Finland (Region: Europe)

National

Sustainable Food Systems, Sustainable Lifestyles and Consumption, Sustainable Production and Value Chains, Sustainable Public Procurement

Sustainable Lifestyles and Education, Consumer Information, Sustainable Food Systems, Sustainable Public Procurement, Sustainable and Safer Production 


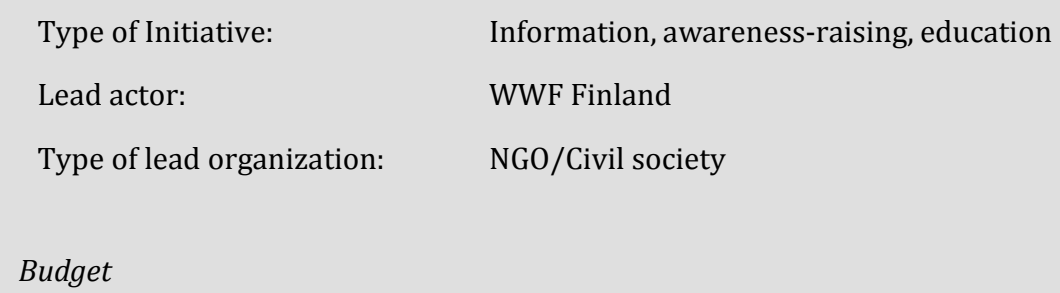

\subsubsection{Introduction}

WWF Finland started a campaign in 2012 to promote sustainable use of fish, especially domestic fish. The campaign included several activities, and targeted consumers and multiple stakeholders in the food value chain. The main objective of the campaign was to increase the consumption of sustainable fish by offering customers as many ethical fish options as possible. The goal was that no unsustainably caught or produced fish should be sold in Finland by the end of 2015. The campaign aimed to influence store procurement and marketing, and to increase customer awareness of sustainable choices, seeking to influence purchasing behavior. The campaign was 
highly successful in influencing consumer choices. The reason behind starting the campaign was that the situation for endangered fish in Finland had deteriorated for some time and no improvement was in sight. Additionally, legislative changes were under way both in Finland and in the EU, which made the timing of the campaign very good.

\subsubsection{Objectives}

The campaign was initiated due to the deterioration of the situation with endangered fish in Finland over the last decades, with no improvement in sight. Additionally, legislative changes were under way both in Finland and in the EU, which made the timing of the campaign very good.

The main objective of the campaign was to increase the consumption of sustainable fish through creating awareness and providing access to as many sustainable choices as possible. The ultimate goal was that no unsustainably caught or produced fish would be sold in Finland by the end of 2015. The means to reach these goals were to both to influence retailer procurement and marketing, and to increase customer awareness of sustainable choices and to impact purchasing behavior. In particular, the campaign aimed to:

- increase the overall sustainability awareness of stores that sell fish and seafood

- increase the sustainability of Finnish fishing practices

- increase the sustainability of aqua culture in Finland and beyond

- influence the legislation in both EU and Finland.

\subsubsection{Activities}

The campaign has targeted multiple stakeholders and included several activities, such as a campaign site on the WWF web pages, a Seafood (choosers) Guide for both consumers and retailers, accessible through multiple channels, including by mobile phone. Apart from consumer-targeted communication, the campaign has also engaged with stores, wholesalers and restaurants that sell fish. The goal has been to influence fish procurement choices and hence to influence the products available for sale to consumers. A specific focus has been on campaigning on behalf of the sustainability of domestic fish. 


\section{Seafood Guide}

One essential part of the campaign is the Seafood guide, which guides consumers to responsible fish consumption through an easily understandable "traffic light" classification system. In the guide, fish species available for food in Finland are classified by green, yellow or red colors. The species with green rating should be favored, those with yellow rating should be bought with consideration, while those with red rating should be avoided. An example is presented below:

Figure 14: Seafood guide has an easily understandable "traffic light" classification system which guides consumers to responsible fish consumption

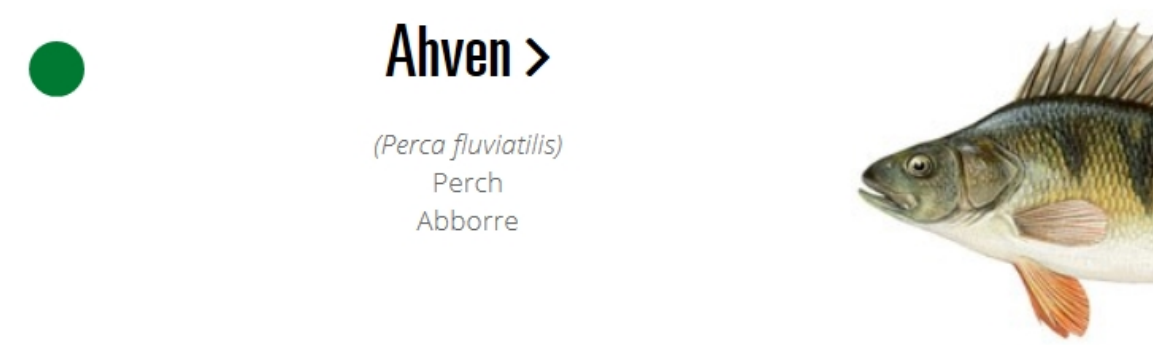

WWF's Seafood Guide was developed as a website, which can also be conveniently accessed by an application on a mobile phone. An icon can be added to the mobile phone startup screen, which enables browsing the guide quickly, also without a network connection. This way the consumer can easily make a sustainable choice at the fish counter or in the restaurant. The Seafood guide classifies the seafood into red, yellow and green categories. One fish can have several sustainability classifications depending on the geographic origin of the fish and how it has been fished.

\section{Active cooperation with stores and the Fish challenge}

Stores that sell fish have been actively included in the campaign. The stores and wholesale sellers have been invited to sign a commitment to promote the sale of sustainable fish and to take concrete steps to avoid the use of "red listed" fish. The challenge was sent to about 100 different stakeholders. As a part of the challenge, the businesses could set their own goals that were evaluated later by WWF and consumers.

Key elements in the campaign were a web page with the published commitments by the stores and the use of social media with videos and other materials. Consumers were also asked to report fish encountered in stores that were on the WWF red list. 


\section{WWF sustainable store competition}

In order to reach the targets of the campaign and to highlight a good example that could serve as a model for other stores, WWF decided to look for a store, which had paid special attention to the sustainability of canned tuna. The invitation to the challenge was sent to almost all stores in greater Helsinki.

The K-market (food store) in Roihuvuori in Helsinki won the challenge by actively promoting the sales of sustainably caught tuna (MSC certified tuna) by reducing the prices of MSC certified tuna products generously and adding distinctive shelf labels to indicate certified products. The stores goal was to offer consumers as many ethical options as possible in addition to the normal selection in order to enable changes in customer purchasing behavior.

\section{Other activities}

WWF participated in different seminars and presentations and trained personnel in stores and restaurants on how to take into consideration the sustainability of seafood.

\subsubsection{Success factors}

Working with the whole value chain has been a highly effective strategy. The combination of working with authorities on legislative issues and including multiple stakeholders such as stores and wholesalers in the campaign has worked well and resulted in good results.

\subsubsection{Key Results and Achievements}

\section{Novelty}

This was the first campaign that also addressed local overfishing in Finland, with one of its goals to reduce the overfishing of endangered local fish. The approach has been inclusive, involving many different stakeholders from the fishing value chain, wholesalers as well as restaurants and food stores that have direct customer contact. Activities were focused on multiple stakeholders in the whole value chain. All activities supported each other well and addressed the whole chain, which was effective. 


\section{Sustainability Impacts}

An extensive survey of stores selling seafood indicated that $62 \%$ of fish are green listed and $35 \%$ are yellow listed. Only $2 \%$ of the fish that are sold are today red listed. Only $1 \%$ of the fish and seafood which was sold could not be rated according to the WWF Seafood Guide. Fishing legislation has been amended to protect several different local fish species. Specific management plans for other species at risk have been drafted. The management plans and cooperation with fishing management authorities in general have already resulted in one species being transferred to the green list and a positive development for several other species. The use of the species roach and bream for fish patties served in schools and personnel restaurants has increased, which is a by product of the campaign.

\section{Challenges and potential for further development}

Many stakeholders have helped the campaign along the way. There has been good cooperation with especially some fishing cooperatives and many other NGOs. The visibility gained through cooperating with wellknown media personalities has also been very useful in highlighting the issue of endangered fish.

Working with the whole value chain has been a highly effective strategy. The combination of working with authorities on legislative issues and including multiple stakeholders in the campaign has worked well and resulted in good results. Even the conflicts with the fishing sector have ultimately been a good thing, because they have forced the government to take some necessary steps in the right direction. 


\subsection{Harvest season calendar}

Figure 15: The harvest season calendar is available as a wall calendar, booklet and mobile application

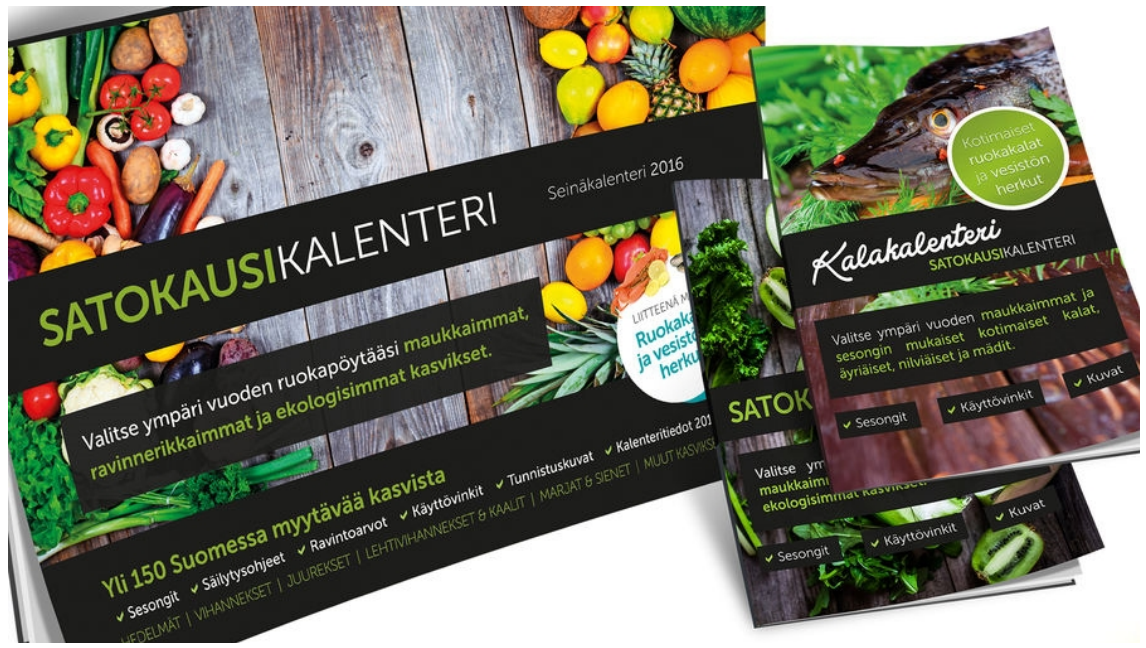

Source: (C) Sesonkia Oy

\section{Case Description}

Country:

Geographic scope:

Theme:

Communities:

Type of Initiative:

Lead actor:

Type of lead organization:
Finland (Region: Europe)

National

Sustainable Food Systems, Sustainable Lifestyles and Consumption, Sustainable Production and Value Chains, Sustainable Public Procurement, Agri-food

Sustainable Lifestyles and Education, Consumer Information, Sustainable Food Systems, Sustainable Public Procurement Information, awareness-raising, education Sesonkia Oy

Business sector

\section{Budget}

The budget has mainly consisted of the work of the developer of the seasonal calendar. 


\section{Partners}

Stores that sell fruits, vegetables and fish are important partners in the concept. There is also cooperation with food sector specialists and re-searchers that have contributed with their expertise.

\section{Status}

Started in 2013. Ongoing.

\section{Next steps}

The next calendar will be published by Otava, which is a major Finnish publishing house and it will be available in all major bookstores in Finland. It will also include wild herbs and fodmap diet recommendations. A fodmap diet is a diet that is designed for people with digestive problems and e.g. irritable bowel syndrome. Fodmap foods will be gentle to the digestive system and alleviate symptoms.

The concept can be directly applied to all Nordic countries regarding imported produce and to local produce in the Nordic area with minor modifications regarding the growth season.

\section{Contact person for more information}

Samuli Karjula:

- samuli.karjula@satokausikalenteri.fi

- info@satokausikalenteri.fi

Note: Case descriptions, e.g. with regards to geographic scope, theme, community, type of initiative, and type of lead organisation, follow the groupings used within UNEP's SCP Clearinghouse.

\subsubsection{Introduction}

The Harvest Season Calendar is a product that shows which vegetables, fruits berries, mushrooms and root vegetables are in season each month in the Nordic area. The 2016 Harvest Season Calendar also includes a Fish Calendar that includes information about the seasonality of over 20 domestic fish, a new addition to the concept. The concept additionally includes a recipe book that presents over 200 recipes using about 50 different vegetables.

Produce that is in season is most tasty and retains a better nutrient content than off-season produce. Eating local or seasonal produce can be a sustainable choice and is also often more economic. The calendar makes 
it easy to identify which fruits and vegetables are at their peak and to find the produce at local stores, thus promoting the use of fruits and vegetables as a part of a healthy and sustainable diet.

The concept and active cooperation with food stores has led to an increase in the consumption of seasonal vegetables and fruits and diversified the choices that consumers make.

\subsubsection{Objectives}

The objective is to change the consumption habits of consumers to include more fruits and vegetables and to diversify the choice of the produce that is being used. This is done by presenting, in an easily accessible manner, what locally sold fruits and vegetables are in season and at their best each month. The aim is to contribute to a healthier more sustainable diet that is also economical. Sustainability is increased by promoting consumption of more locally seasonally produced fruits, vegetables, and berries, which thus require less energy for especially production but also transports.

\subsubsection{Activities}

The communication concept of the calendar has targeted both consumers and shops. It includes the calendar, which can be accessed by consumers via multiple channels and downloaded to a mobile phone. Stores, wholesalers and restaurants have started to use the calendar to influence consumer choices of fruits, vegetables, berries and lately also fish.

\section{Fruit and vegetable calendar}

The calendar includes over 150 locally available fruits, vegetables, berries and commercially sold mushrooms and root vegetables and their seasonality. The fruit and vegetable calendar makes it possible for anyone to stay up to date on which produce is at its best each month. The fact that stores have started to use it in marketing and presentation of fruits and vegetables in their stores has contributed to making it easier for consumers to find the produce.

The contents of the 60-page guide are the following:

- Over 150 domestically sold fruits, vegetables, root vegetables, mushrooms and berries.

- Seasonality for both domestic and imported fruits and vegetables by country of origin and month. 
- For domestic produce that can be stored, the months when they are still good to consume.

- Recommended storage temperatures for ripe produce.

- Pictures that help identify produce, a guide for choosing as well as useful hints for using produce.

- Nutrient content of the fruits and vegetables.

The calendar sold on the www.satokalenteri.fi website; the app is sold on Google play and App store. The calendar is also available for sale at some food stores and bookstores.

\section{Fish calendar}

A newly added part of the Harvest Season Calendar is the Fish Calendar, which guides consumers to consume domestic fish when it is seasonally best available. The fish calendar is a new concept that has been added to the fruit and vegetable calendar.

\section{Recipe book}

The concept also includes a recipe book that presents over 200 recipes using about 50 different vegetables. The book is organized so that the recipes follow the seasons and use the produce that is at its best each season. The recipes include inspiration from other cultures where vegetable use in cooking is more extensive.

\section{Active cooperation with stores}

The Harvest Season Calendar team has built cooperation with some food store chains. Stores have started to use the calendar actively in marketing. Recipes using especially seasonal produce have been featured in marketing materials and the seasonal vegetables are prominently marketed and presented in many stores.

\subsubsection{Success factors}

The success factors have been the commitment from the developers as well as the need and interest for this type of service. Both consumers and food stores have shown a very active interest and have taken actions to adopt recommendations in daily life and in business processes. 


\subsubsection{Key Results and Achievements}

\section{Novelty}

This type of concept is new in Finland. Finnish consumption of fruits and vegetables has traditionally been limited to a few basic vegetables and fruits. Finns generally consume fewer than 10 types of vegetables on average. Knowledge has been low in the general population of when different produce is at its best and cheapest, and how to use many fruits and vegetables in cooking. Previously common knowledge about the seasonality and peak times for certain produce has been lost and the more exotic varieties are little known.

The seasonal calendar has in part contributed to reviving the concept of seasonal consumption and has contributed to broadening the knowledge of the general population of more exotic produce and their uses in food preparation.

\section{Sustainability Impacts}

The seasonal calendar has contributed to diversifying the fruits and vegetables bought at stores. For instance, the S-market food retail chain has increased the sales of different types of fruits and vegetables dramatically as a result of the cooperation with the seasonal calendar. The sales of fruits and vegetables has in general increased by 12 million kilos in 2015. Some examples of the impact on specific produce are yellow garden beets with a 30 -fold and pumpkin with a 10 -fold increase compared to previous sales.

The calendar concept has about 65,000 Facebook followers. The concept has influenced the catering sector as well as hotels and restaurants. It has also had an impact on food writers and bloggers that have quite a lot of impact on consumption patterns in modern societies.

\section{Challenges and potential for further development}

Food is a personal issue and preaching and negative communication is not effective. Positive communication and examples work much better. The experience gained from the seasonal calendar activities has indicated that what consumers are most interested in is cost savings and the taste of the food. Experience has also shown that the threshold for adopting new behaviors and using new produce in different ways needs to be very low. Only some consumers have a genuine interest in food and will adopt the messages.

At the moment there are many food related beliefs that are not based on scientific facts and much disinformation is being spread about food, which is confusing for consumers. 



\section{Norway}

\subsection{Matvett - information concept for food waste reduction towards consumers}

Figure 16: Food Waste Table illustrating the yearly amount of different categories of food wasted by an average Norwegian

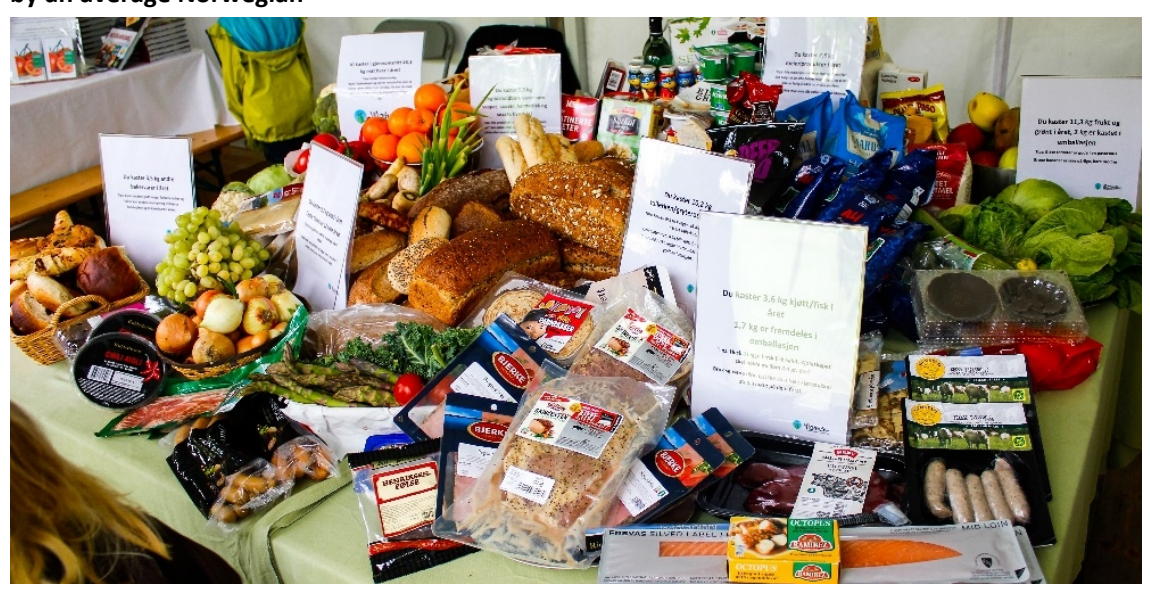

Source: () Matvett.no

\section{Case Description}

Country: Norway (Region: Europe)

Geographic scope: National

Theme:

Sustainable Food Systems, Sustainable Lifestyles and Consumption, Awareness-raising and Education for SCP; Media, Advertizing and Marketing, Waste

Community:

Sustainable Lifestyles and Education, Consumer Information, Scientific Knowledge, SCP National Policy Frameworks/Strategies, Sustainable Food Systems

Type of Initiative: Information, awareness-raising, education

Lead actor: Matvett AS

Type of lead Business sector

organization: 


\section{Budget}

The yearly budget of Matvett's communication platform is around EUR 54,000.

\section{Partners}

Matvett is owned by organizations in the food sector; the Food and Drink section of the Confederation of Norwegian Enterprise (NHO Mat og Drikke), the Norwegian Grocery Sector's Environmental Forum (DMF), the Grocery Producers of Norway (DLF) and the Norwegian Hospitality Association (NHO Reiseliv). The company is financed by the Norwegian government and 32 food industry companies. Ostfold Research is responsible for the mapping and analysis of food waste.

Matvett also cooperates with the food research institute Nofima that provides expert advice on food safety, the environment and communication.

\section{Status}

Started in 2010. Ongoing.

\section{Next steps}

The company continues to actively collaborate with different kinds of actors to keep the topic in public discussions and to raise media attention.

Matvett is also working to get the Norwegian Ministry of education to integrate food waste reduction as a part of teaching curricula.

Contact person for more information

Anne Marie Schrøder, ams@matvett.no

Note: Case descriptions, e.g. with regards to geographic scope, theme, community, type of initiative, and type of lead organisation, follow the groupings used within UNEP's SCP Clearinghouse.

\subsubsection{Introduction}

Matvett aims to reduce unnecessary food waste by collaborating with the food value chain and spreading consumer information. Matvett's communication platform towards the consumer consists of:

- Web-based communication through matvett.no and social media in collaboration with others. 
- Communication Materials: Brochures with "Matvett's 10 tips" to reduce food waste by better planning and storing, "Leftover love" Cookbook.

- One-to-one communication to raise awareness and knowledge, with exhibition of the "Food waste table", quiz and leftover food.

Matvett has successfully attracted the attention of the general public, politicians, media and private sector. Since the launch of the communication platform, consumer's awareness about food waste as a problem and their own role in waste prevention has increased. The platform is operated by Matvett AS, a company, owned by the food sector and financed by the Norwegian government and food industry.

\subsubsection{Objectives}

The objective is to reduce food waste by collaborating with different interest groups and by providing consumer information.

\subsubsection{Activities}

When researching food waste amounts and sources in Norway, Matvett working with Ostfold Research established that consumers were responsible for the largest share of food waste, $64 \%$. Therefore, more in depth research was made about consumer behavior as well as the amounts and types of food wasted. The research results revealed that young people were responsible for most of the food waste. The study also showed that most of the food was wasted because the best before date had expired.

Matvett created the Matvett.no website to provide consumers with motivating information about simple ways to prevent food waste. One of the main focus areas of Matvett has been to reduce food waste caused by an expiration of the "best before date". There is a significant difference between the "best before date", which is a guideline and the "last use date", which should be strictly followed. In order to change this behavior, consumers need to feel safe about using food products where the "best before" date has expired. Therefore, Matvett has right from the start collaborated with the Norwegian national authorities and research institutes institutions providing advices on food safety. Matvett has also collected information from food producers about how long each product remains fit for consumption after the "best before" date. 
The kickoff event aimed at consumers took place in June 2011 and consisted of a free lunch made from food products where the "best before" date had expired. The event was organized in front of the Parliament building in Oslo, and participators included many politicians as well as Tristram Stuart the internationally famous British campaigner against food waste. The lunch was a great success and attracted many citizens and media representatives.

The Matvett.no website was launched in early 2012 to both raise awareness, inspire and inform consumers. The website contains some 100 recipes and gives simple rules of how to take better care of food, covering topics such as meal planning, storage and reusing leftovers.

In addition to the website, Matvett has created concepts such as Leftover Thursday and Food Waste Table. The idea of the Leftover Thursday is that leftovers from the beginning of the week would be used for cooking on Thursdays and that all food has a value and still tastes good even if it is not fresh. Cooking recipes utilizing leftover food as ingredients are provided through the website and a Facebook group. Matvett has also organized events such as "The National Leftover Thursday" together with partners, once with The Peace Centre and once with the Consumer Council. The focus has been on raising awareness amongst children and young people, serving expired food, such as yoghurt and showing the Food Waste table. This is an exhibition illustrating the amount of food that is wasted each year by an average Norwegian. The table is presented for example in shopping centers during Leftover Thursdays, festivals, food fares and other events.

\subsubsection{Success factors}

One of the main success factors has been the collaborative approach that Matvett has applied since the beginning. Matvett collaborates with the entire food value chain from industry to retailers and the hospitality sector, which has enabled spreading consumer information through the value chain members. In addition, cooperation has been made with governmental agencies, NGO's, schools, business sector, food bloggers and media.

Starting the work by identifying the sources, reasons and types of food waste was also crucial for successful communication concept development. 


\subsubsection{Key Results and Achievements}

Novelty

Food waste was not recognized as a major problem in Norway when Matvett started. Through 5 years systematic research and the collaborative approach with the entire food value chain, politicians, media and companies in general, Matvett has succeeded adding food waste reduction on the Norwegian agenda. Matvett has innovated concepts such as National Leftover Thursday and the Leftover Food Table that can be used by partners.

\section{Sustainability Impacts}

Norwegians throw away over 230,000 tons of food annually that could have been eaten, equal to 46.3 kilos per person. According to the consumer surveys conducted between 2010 and 2015, there is an increase in the percentage of consumers who report having discarded less food and the percentage who are more conscious of it being a problem that they discard food themselves. The percentage of consumers that report buying too large quantities or units of food has decreased. This trend may indicate that consumer-oriented campaigns from the producer and retail sectors, together with efforts to change attitudes and awareness by Matvett, have led to consumers changing their habits.

Between April 2015 and 2016, Matvett.no has attracted over 69,000 visits. Around $80 \%$ of the visits have been from new users. The average website visits per day is around 200. Matvett's Facebook group has over 6,000 followers. An online awareness raising campaign about resource efficiency during christmas time in 2015 resulted in a high peak of visitors on matvett.no and facebook. The campaign was organized together with the department of Children-, Equality and Social Inclusion.

Matvett's successful work has attracted the attention of companies and food bloggers. For example, companies such as Ikea and Siemens have expressed their interest in cooperating with Matvett for running campaign on food waste, for example related to correct food storing. In addition, e.g. food bloggers have shared the leftover food receipts.

Since Matvett has only two employees, collaboration with companies and NGOs has been crucial for scaling up the activities and achieving visibility. For example, fridge manufacturers have cooperated by spreading the word about correct storage and NGO's have presented the Food Waste Table in different events. 
Matvett has also improved the cost efficiency of its online campaigns. For example, Matvett achieved 13,000 clicks with a budget of EUR 16,000 during its Christmas online campaign on resource efficiency. This campaign showed 38\% lower cost per clicks than other similar campaigns.

\section{Challenges and potential for further development}

Extensive work has been conducted on date labelling in the industry, where the date label has been changed from "use by" to "best before" on several kinds of food such as dairy products and whole pieces of meat. However, consumer surveys still show a slight increase over the past year in the proportion of consumers who say they throw away food only because it is past its expiry date. This suggests that work still needs to be done on consumer attitudes and understanding of what date labels on food means. 


\subsection{Sortere.no - a web based recycling guide for consumers}

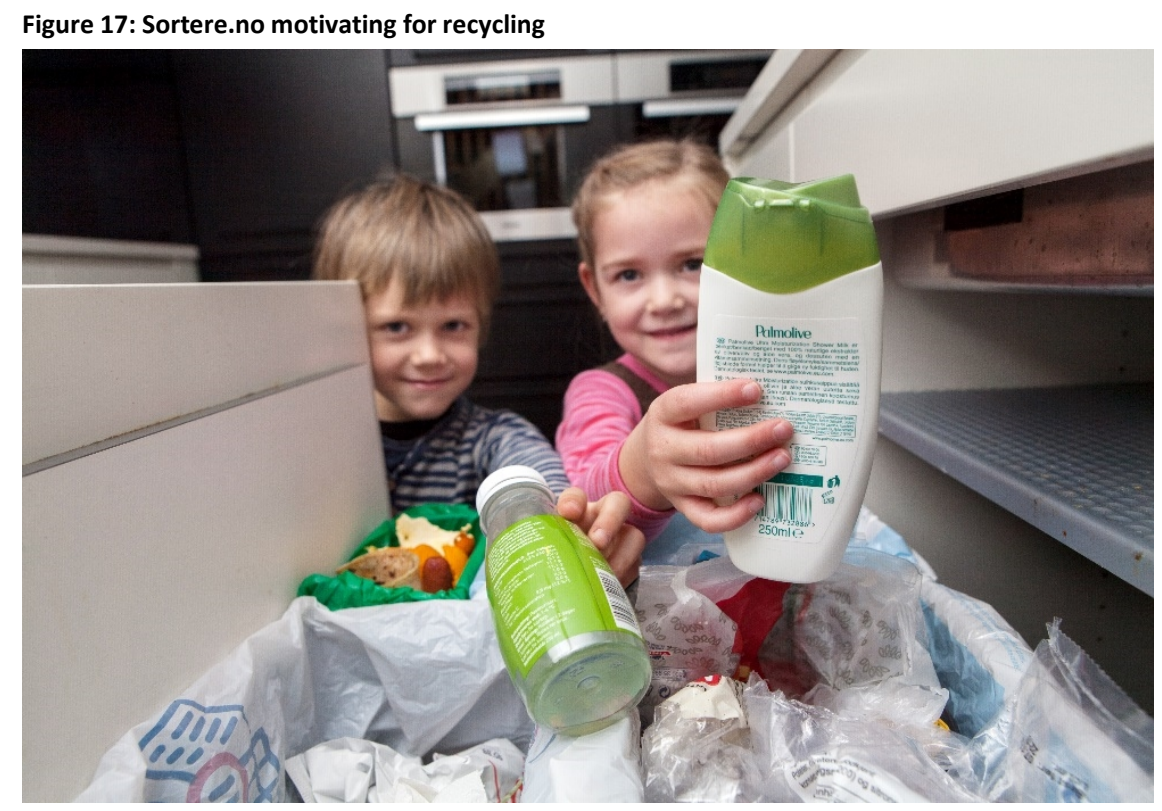

Source: @ Johnny Syversen/LOOP

\section{Case Description}

Country:

Geographic scope:

Theme:

Community

Type of Initiative:

Lead actor:

Type of lead organization:

\section{Norway (Region: Europe)}

National

Waste, Sustainable Lifestyles and Consumption

Sustainable Lifestyles and Education, Consumer Information

Information, awareness-raising, education The LOOP foundation

Foundation 


\section{Budget}

The service Sortere.no is financed by different contributors. Sortere.no is mainly financed by EPR (extended producer responsibility) companies for packaging and electronic waste, municipalities and inter municipal waste managements, the organisation Waste Norway and the Norwegian Ministry of Environment.

This is a concerted effort to finance operating, maintenance and further development of Sortere.no. In addition, projects can be initiated and financed to further develop Sortere.no. The financing comes partly through direct financing to Sortere.no and partly through distributed finances through LOOP. The LOOP foundation was founded by EPR companies for packaging and electronic waste in the year 2000. The founding of LOOP was also supported by the Norwegian Ministry of Environment.

\section{Partners}

The LOOP foundation is mainly financed by EPR companies for packaging and electronic waste, municipalities and inter municipal waste managements, the organisation Waste Norway and the Norwegian Ministry of Environment. Sortere.no collaborates with several web portals in order to reach more people. These portals include Yellow pages, 1881.no and finn.no. This is in addition to all the local versions of Sortere.no that are used by the municipalities.

\section{Status}

Started in 2009. Ongoing.

\section{Next steps}

Sortere.no will launch a new campaign in 2016-2017 that will focus on reducing residual waste. The campaign is inspired by the health and fitness industry and will use rhetoric typically used in weight loss campaigns to inspire people to cut down their amount of residual waste. Partners and financial contributors in the campaign so far are Green Dot Norway, Syklus (EPR company for glass and metal), the Norwegian Ministry of Environment and approximately 30 municipal waste management companies.

\section{Contact person for more information}

Sylvelin Aadland, sylvelin@loop.no

Note: Case descriptions, e.g. with regards to geographic scope, theme, community, type of initiative, and type of lead organisation, follow the groupings used within UNEP's SCP Clearinghouse. 


\subsubsection{Introduction}

Sortere.no is a unique web based guide for consumers on waste separation and recycling. On Sortere.no consumers can search for information on how to sort and recycle thousands of products and find collection points in their municipality on a map.

Sortere.no is a database for sharing information about sorting and recycling nation-wide. With the help of municipalities, EPR (extended producer responsibility) companies, Waste Norway and various governmental institutions it is made sure that the information is correct and up to date. The collection of household waste varies quite a bit from one municipality to another, but on Sortere.no all Norwegians can find correct local information whether they are at home, visiting another part of the country, or if they have just moved to a new place.

Information from Sortere.no is very flexible and currently several forms of data exchange are available, e.g. APIs (application programming interface) and an adjustable iframe solution.

\subsubsection{Objectives}

The main objective of Sortere.no is to contribute to more and better source separation and recycling of waste through:

- increasing knowledge and sharing information about source separation and recycling of waste

- motivating consumers to act more environmental friendly, mainly through recycling their waste

- making source separation easier for consumers

- making sure that the information shared is accurate and up to date.

The LOOP foundation promotes recycling in Norway, among consumers, kindergartens, schools and businesses. LOOP's vision is “We create good habits" (Vi skaper gode vaner).

\subsubsection{Activities}

Sortere.no was published in 2009 and was officially opened by the Minister of Environment. Since then, the website has constantly been updated and improved. For example, in 2015 a massive project to optimize the website for mobile phones was carried out. 
Sortere.no is a shared database for national and local information. All Norwegian municipalities can access and edit information in the Sortere Database. Thus, Sortere.no has 200 local administrators in 76 municipal waste companies all over the country, who provide the correct local information for their region. In addition, Sortere.no cooperates with the EPR companies, Waste Norway and various governmental institutions to ensure that the information is kept up to date.

Sortere has developed APIs (application programming interfaces) for information exchange, which allow third parties to use the information on their own website, in apps, map services etc as open data. An adjustable iframe solution is also available, enabling municipalities and waste managements to implement a local version of Sortere.no on their own website. These tools make the information on sorting and recycling widely spread, so people will find it whether they search on Sortere.no, their municipality's website, on Yellow Pages or other websites. The first API was developed together with the largest web portal in Norway (finn.no).

Media campaigns are also an important way to reach people. Waste Norway, the interest organisation for private and municipal waste management companies, gathers all its members to participate in biannual national campaigns. Sortere.no has on two occasions (2012 and 2014) represented the common voice of all Norwegian waste companies in these campaigns. Each campaign has a theme. For example in 2014, the national campaign was about hazardous and electronic waste. There have also been PR activities in national press (e.g. battery campaigns).

Sortere.no also has an active presence on social media, mainly in Facebook, but Twitter and Instagram are also used on occasion. Cooperation with all collaborators of Sortere.no and other companies also helps to get media attention. Examples of such cooperation are an ongoing campaign with Green Dot Norway and the campaign from 2014 about WEEE (waste electrical and electronic equipment) and hazardous waste in collaboration with Avfall Norge (Norwegian Waste Management and Recycling Association), EPR companies and municipalities.

The Sortere.no team has a continuous focus on improving the quality of information. This involves communication with the 200 local administrators, via Facebook, newsletters and meetings.

During spring 2016, Sortere.no will launch a recycling guide for companies (Sortere Bedrift). The guide will include:

- Practical information on how different types of waste should be handled and a possibility to search among thousands of products.

- Overview of waste companies, including map overview. 
- Information about what different laws and regulations mean for companies in practice.

- Information of benefits and incentives of recycling.

This is a major project that has been in the pipeline for some years. It will help companies to understand for example what waste they can deliver for free, how do reduce waste, and how to embrace the concept of circular economy. The guide can be used by all enterprises, but has a focus on small and medium sized enterprises. The guide will be published with the help of partners and financial contributors from the private waste sector, municipal waste management companies, interest organisations and EPR companies.

\subsubsection{Success factors}

The shared database enables Sortere.no to share information widely and still be sure that the source of information is correct and up to date. The success depends both on the accuracy of the information and on the large reach. The first one is important in order for Sortere.no to appeal to consumers. The second one is important to partners financing the site, which again makes it possible to run and keep up the site also in the future.

The popularity of Sortere.no is also a success indicator. The website visits have increased yearly. As the information is also spread to many other different websites through data sharing via APIs, the number of calls to the database is tracked, which is also showing an increase.

\subsubsection{Key Results and Achievements}

\section{Novelty}

Sortere.no has gained a wide reach in the population and the usage of information provided through it is increasing. 76 municipal waste companies have signed up to and are using Sortere.no as a tool to communicate nationally about recycling. Through their participation, Sortere.no has covered over $90 \%$ of the population. Sortere also serves as a common voice in national campaigns.

The result of the collaboration is that all contributors can use high quality material in their own communication. This especially benefits the small and medium municipalities and waste management companies, as they often lack resources to do this on their own. 


\section{Sustainability Impacts}

Sustainability impacts of Sortere.no have not been verified yet, but the amount of visitors is followed-up regularly. Sortere.no has increased visits year on year, e.g. by 57\% from 2014 to 2015. In 2015 Sortere.no had 130,000 unique users (verified through google analytics). In 2015 the number of calls to the database reached 1.6 million, an increase of approximately $50 \%$ from 2014 . The objectives of Sortere.no - to contribute to better source separation and recycling of waste - seem to interest Norwegians.

\section{Challenges and potential for further development}

Funding is always a challenge. In addition, continuous development of the website, e.g. keeping up with the standards of a good website, is a challenge itself.

Even though Sortere.no is quite comprehensive, there are areas for further development. For example, the whole database and website are only available in Norwegian. An English version of the website is something that LOOP will investigate further and search for financial partners to carry out the translation.

The LOOP foundation has no means to measure the direct effect Sortere.no has had on individual recycling behaviour or amounts of waste produced. However, there are many initiatives, for example locally and at EPR companies that can influence the behaviour and the way people recycle. 


\title{
10. Sweden
}

\author{
10.1 Hello Consumer - Hallå konsument \\ by the Swedish Consumer Agency
}

Figure 18: Hallå Konsument - Hello Consumer is a Swedish national information service for consumers

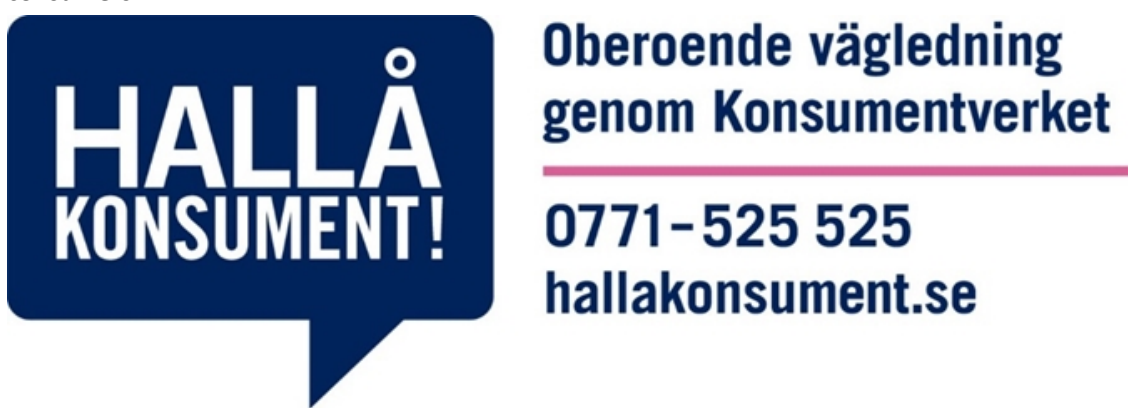

\section{Case Description}

Country:

Sweden (Region: Europe)

Geographic scope:

National

Theme:

Sustainable Lifestyles and Consumption, Awareness-raising and Education for SCP

Community: Energy Efficiency, Sustainable Lifestyles and Education, Consumer Information, Sustainable Food Systems

Type of Initiative: Information, awareness-raising, education

Lead actor: Swedish Consumer Agency

Type of lead organization: Government 


\section{Budget}

The total budget in 2015 was about EUR 3.8 million, which included personnel costs for customer service.

\section{Partners}

The Swedish Consumer Agency (coordinator), The Swedish National Board for Consumer Complaints, the Swedish National Board of Housing, The Energy Markets Inspectorate, The Swedish Estate Agents Inspectorate, The Financial Supervisory Authority, The Swedish Chemicals Agency, The Swedish Enforcement Authority, The National Food Agency, The Swedish Environmental Protection Agency, The Swedish Pensions Agency, The Swedish Post and Telecom Agency, The Swedish Energy Agency, The Swedish Consumers' Banking and Finance Bureau, The Swedish Consumer Energy Markets Bureau, The Swedish Consumers' Insurance Bureau, Telekområdgivarna (The Telecom Advisors) and municipal consumer guidance organisations across Sweden.

\section{Status}

Started in 2015. Ongoing.

\section{Next steps}

Sustainability will be a future focus area as the service is developed in the future. Some useful online tools will be developed for consumers. One particular objective will be to try to guide consumers to use the service before making decisions or purchases, instead of contacting authorities when problems have already been encountered.

Contact person for more information

- Lars Boström, web coordinator, lars.bostrom@konsumentverket.se

- Eva Holmgren, content coordinator, eva.holmgren@konsumentverket.se

Note: Case descriptions, e.g. with regards to geographic scope, theme, community, type of initiative, and type of lead organisation, follow the groupings used within UNEP's SCP Clearinghouse.

\subsubsection{Introduction}

Hallå Konsument - Hello Consumer is a Swedish national information service. The service provides useful consumer information via one point of access using multiple channels, including web page, e-mail, Facebook, chat, Twitter and phone. It provides access to consumer advisors who 
answer consumers' questions related to purchases and provide information on consumer rights, personal finance and making sustainable choices. The service has been set up in collaboration with over 12 government agencies. It brings services provided by both government agencies and municipalities under one umbrella in an easily accessible manner. The service doesn't require the consumer to have any previous knowledge of what governmental agency is responsible for the information the consumer is looking for. The goal is to make it possible for consumers to easily access impartial information on consumer related issues through channels that are most convenient for the consumer, thus enabling making better choices.

\subsubsection{Objectives}

The purpose of the information service is to make things easier for consumers and to give quick and useful answers that will help consumers make informed choices. The Hello Consumer service brings information services that are provided by several different government agencies as well as municipalities under one umbrella with the aim to provide consumer services in a more convenient manner.

\subsubsection{Activities}

The Hello Consumer service was launched in 2015. It provides consumer information using several different channels, e.g. web, Facebook, Twitter, Chat, e-mail and phone, in order to reach consumers in different situations by the most convenient means of communication. The concept brings services that are provided by government agencies as well as municipalities under one umbrella. It doesn't require the consumer to have any previous knowledge of what governmental agency is responsible for the information or service that the consumer is looking for.

Hello Consumer can provide answers to the following types of questions:

- Answer consumers' questions on buying goods and services, reclamations and on consumer related legislation and protection.

- Give guidance before buying goods or services in order to promote making informed choices.

- Give guidance on sustainable and environmentally friendly consumption. 
- Give guidance on which experts to contact in different types of consumer related issues at different governmental and consumer agencies and in municipalities that provide guidance services.

Answers to particular questions are provided as promptly as possible on weekdays between 9 and 17 in Swedish and English. The answer time targets in the different communication channels are as follows:

- Telephone - callback with a maximum waiting time of 3 minutes.

- Chat - an answer within 5 minutes.

- E-mail - an answer within 24 hours.

- Facebook - an answer within 24 hours.

- Twitter - an answer within 4 hours.

The service has been designed with the cooperation of consumers and in accordance with design principles used when designing public services in Sweden. Advanced prototyping, focus groups, usability studies as well as involvement of handicapped and challenged consumers through the Begripsan organization were used in the design of the service in order to guarantee good accessibility and relevance of the service for different types of consumers and their specific needs. Begripsan is an organization that represents the handicapped or challenged.

At the launch of the service it was marketed through multiple channels. There were contact points at three major train stations and advertising on the serving trays in trains. Online marketing was also used: a YouTube video of the service, advertising in Google search engine. Additionally, the service was marketed with fliers in family oriented magazines.

\subsubsection{Success factors}

The involvement of reference groups from the government agencies in the development process from the start has been an important success factor. Timely input into planning from the right people made the implementation and planning process successful.

\subsubsection{Key Results and Achievements}

The initiative is ongoing in 2016 and the service is known to 16\% of consumers in Sweden, which is considered a good result in less than a year of operation. 
According to user research, the users are quite satisfied with the service. About $80 \%$ are very satisfied with their contact and about $85 \%$ have thought that the service has been impartial and easy to understand. About $80 \%$ feel that the information has been relevant and that answers provided are timely. The website has also received a positive evaluation, with $80 \%$ of users feeling that the information is impartial and easily understandable and two thirds feeling that the information has been adapted to their needs.

\section{Novelty}

This type of service exists in some other countries, but is usually based on cooperation between fewer government agencies. Hence, in comparison this service is more comprehensive than many others.

\section{Sustainability Impacts}

Sustainability impacts have not been measured yet in 2016. Sustainability related advice and topics are a future focus area as the service is further developed.

The main goals have not been cost savings, but that consumers should receive better service through convenient service channels. The service has despite this had some impact and potential savings by channeling some questions, which the municipalities have previously handled, to the Hello Consumer portal. Calls to municipalities have thus been fewer.

\section{Challenges and potential for further development}

The service has been well received from the start and has worked well. The main challenge relates to the resources that have been available for the phone service. Initially, when the marketing was intense, the phone service resources were insufficient. This aspect will be taken into account when future marketing efforts are planned. Efforts will also be made to try to guide people to the web service instead of to the telephone service.

The involvement of reference groups from the government agencies in the development process from the start has worked very well. Timely input into planning from the right people made the implementation and planning process successful. 


\subsection{Green Guide App by Swedish Society for Nature Conservation}

Figure 19: Grön Guide is a mobile application on sustainable choices

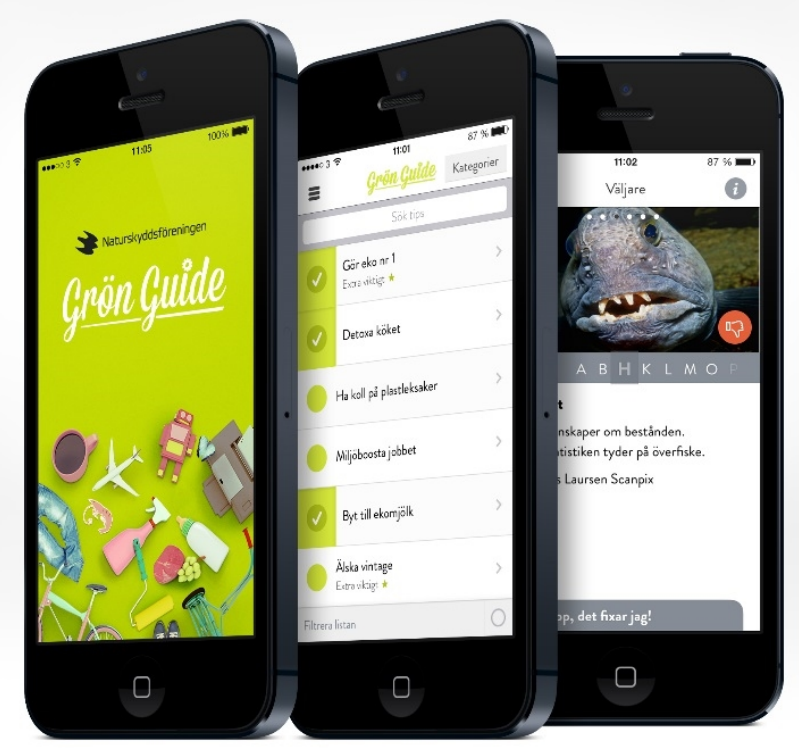

Source: (C) Ulrica Zwenger

\section{Case Description}

Country:

Sweden (Region: Europe)

Geographic scope:

National

Theme:

Sustainable Lifestyles and Consumption, Sustainable Production and Value Chains, Lifecycle Perspective

Communities: Sustainable Lifestyles and Education, Consumer Information, Sustainable Food Systems

Type of Initiative: Information, awareness-raising, education

Lead actor:

Swedish Society for Nature Conservation

Type of lead organization: NGO/Civil society 
Status

Started in 2011. Ongoing.

Next steps

The application will continue to be developed.

Contact person for more information

Manja Hellbom, manja.hellbom@naturskyddsforeningen.se

Note: Case descriptions, e.g. with regards to geographic scope, theme, community, type of initiative, and type of lead organisation, follow the groupings used within UNEP's SCP Clearinghouse.

\subsubsection{Introduction}

The Green Guide App by the Swedish Society for Nature Conservation (Naturskyddsföreningen) presents useful information on consuming sustainably and on how to make environmentally conscious decisions via a mobile application. In the Green Guide, consumers can browse through various themes - the home, food, children, travel, clothes, work and the garden - and learn the essentials of being a green consumer. The advice is easily accessible in different situations and helps consumers to shift towards a more sustainable lifestyle. Information is seen as the basis of enabling consumer change. The app focuses predominantly on environmental issues.

\subsubsection{Objectives}

With the Green Guide mobile application the Swedish Society of Nature Conservation aims to help consumers consume sustainably and to make environmentally conscious decisions. The advice presented in the application intends to allow consumers to shift to a more sustainable lifestyle and to increase awareness of climate change and its link to consumption. The main objective is to present information in an easily accessible and attractive manner. 


\subsubsection{Activities}

The Green Guide App by the Swedish Society for Nature Conservation (Naturskyddsföreningen) functions as a database that contains useful information on consuming sustainably and on how to make environmentally conscious decisions. In the guide, consumers can browse through various green consumption themes and learn the essentials of being a green consumer. The advice is intended to allow consumers to shift to a more sustainable lifestyle. The guide focuses predominantly on environmental issues.

By using the application consumers can find simple advice on reducing environmental impacts. "Tips (advice)" give practical advice on how to eat, live, buy and travel in a more environmentally conscious way. The advice ranges from recommending green insurance services to advice on sustainable food choices or travel tips. The advice can be accessed conveniently by the mobile application and provides on line advice in different situations. The tips can be shared with others via Facebook and Twitter.

In the section "Make the right choice" consumers get advice on sustainable food choices. There are four sub categories to choose from: Fish picker, Fruit picker, Vegetable picker and Recycler. The app also presents information on different types of environmental labels to make it easier to keep track of a multitude of labels that may otherwise cause confusion. The "Find a store" section helps the consumer find nearby stores that sell ecological clothes.

\section{Environmentally friendly office}

The app also has a category on the office, which aims to promote sustainability at the office. It helps plan meetings that take into account environmental considerations and gives tips on environmental issues related to procurement of goods needed at the office.

\section{Pledging and share function}

The app also features a pledging function. Users of the Green Guide App are encouraged to select certain actions and then "pledge" to carry them out later. Pledges are then recorded on individual users' status profiles according to levels of commitment to the "green cause" as suggested by the Green Guide system. You can earn points and can become a "Environmental hero". Users are given the opportunity to share their pledge and scores with others through Facebook and twitter. With a click of a button, the user goes from private to the public domain. 


\subsubsection{Success factors}

The main success factors are ease of use and accessibility in different situations. Also, a key success factor is the high level of credibility that the Swedish Society for Nature Conservation has earned among the public. This reflects positively on the information that is presented in the mobile application.

\subsubsection{Key Results and Achievements}

\section{Novelty}

The application had an element of novelty at the time that it was launched. At launch, it generated much attention. The application received very favorable reviews. Currently it is regarded as easy to use and users seem satisfied. The application has been downloaded about 150,000 times and with no marketing efforts there are currently about 500 active weekly users.

\section{Sustainability Impacts}

Specific information on the concrete impact on user consumption behavior does not exist as yet. However, the application is used by consumers and the most frequently accessed information is on food and chemicals. Some popular themes are Detox your kitchen, Eat less meat, Switch to eco milk, Detox the preschool as well as Clean the cleaning cabinet.

The principle behind the mobile application has been to regard ethical consumers as rational individuals and as socio-cultural beings. The app is designed as an answer to two often discussed challenges related to promoting ethical consumption - how to handle complexity and how to motivate consumers. By using these green apps consumers can manage complexity by getting easily understandable information on green choices in a very accessible manner. It also makes it possible for consumers to make more informed ethical choices while at the same time "profiling themselves" as ethical consumers in their own eyes as well as socially. 



\title{
11. Regional
}

\author{
11.1 The Nordic Ecolabel - The Swan
}

Figure 20: The Nordic Swan Ecolabel was established in 1989 by the Nordic Council of Ministers

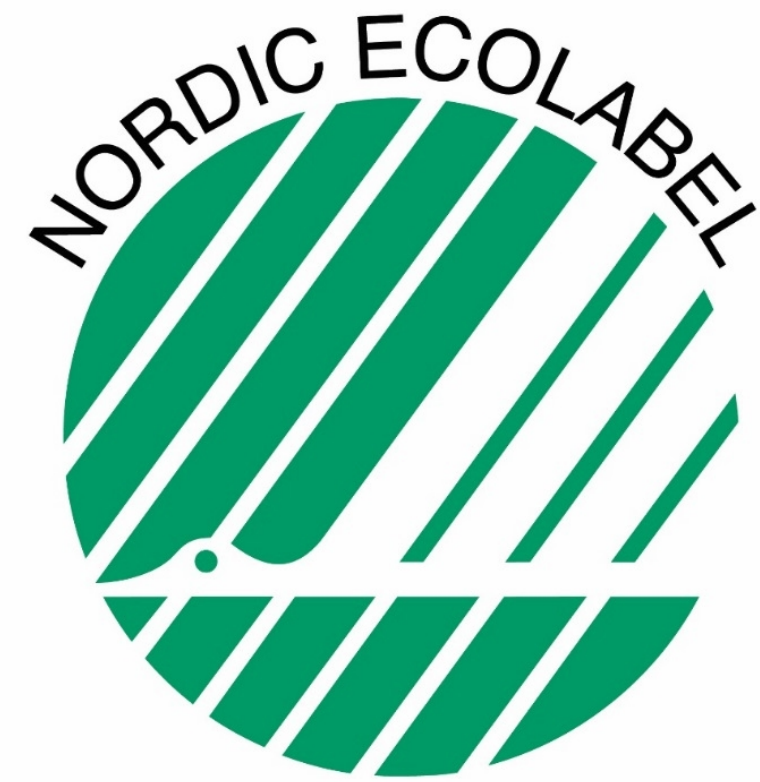

Case Description

Country:

Denmark, Finland, Iceland, Norway, Sweden (Region: Europe)

Geographic scope: Sub-regional

Theme: SPP and Ecolabelling, Sustainable Food Systems, Sustainable Lifestyles and Consumption, Sustainable Production and Value Chains, Sustainable Public Procurement, Awareness-raising and Education for SCP, Chemicals, Energy, Retailing, Tourism, Waste, Water, Lifecycle Perspective 


\author{
Communities: \\ Consumer Information, Energy Efficiency, \\ Sustainable Lifestyles and Education, Sus- \\ tainable Food Systems, Sustainable Public \\ Procurement, Sustainable and Safer Pro- \\ duction, Sustainable Tourism \\ Type of Initiative: \\ Information, awareness-raising, education \\ Lead actor: \\ Nordic Council of Ministers \\ Type of lead organization:
}

\section{Budget}

The annual budget for campaign and communication activities is around EUR 200,000 on country level. A typical communication campaign for the Nordic Ecolabel, using primarily digital media, c77osts about EUR 75,000. The yearly turnover of the Nordic Ecolabel is around EUR 12.8 million and it employs 125 people. The yearly budget of the Nordic Council of Ministers is approximately EUR 550,000 EUR (2014-2016). Costs for operations are also financed by licensing fees.

\section{Partners}

The Nordic Ecolabelling Association coordinates label activities. Its members are the organizations that are responsible for the Nordic Swan Ecolabel in each Nordic country (Denmark, Finland, Iceland, Norway and Sweden). The association's board members are the CEOs in their country's labelling organization and they coordinate the licensing, marketing and criteria development processes. The Nordic Council of Ministers is the highest governing body.

There is also extensive cooperation with other ecolabels in the Nordic countries with some joint activities.

Status

Started in 1989. Ongoing.

Next steps

More Pan-Nordic campaigns are planned in the future to be able to use common communication concepts efficiently and to further strengthen the Nordic focus and brand.

Some future expansion can be foreseen beyond the Nordic region. The Nordic brand is currently seen as very strong in general, even globally, and is associated with multiple positive values. This could be useful in expanding the Nordic Swan Ecolabel internationally. 
Contact person for more information

- Denmark: Charlotte Rajsager, cr@ecolabel.dk

- Finland: Hanna Sauroja, hanna.sauroja@ecolabel.fi

- Iceland: Elva Rakel Jonsdottir, elva@Umhverfisstofnun.is

- Norway: Anne-Grethe Henriksen, agh@svanemerket.no

- Sweden: Nancy Holm, nancy.holm@svanen.se

Note: Case descriptions, e.g. with regards to geographic scope, theme, community, type of initiative, and type of lead organisation, follow the groupings used within UNEP's SCP Clearinghouse.

\subsubsection{Introduction}

The Nordic Swan Ecolabel is the official eco-label of the Nordic countries. It was established in 1989 by the Nordic Council of Ministers. The purpose of this Ecolabel is to contribute to sustainable consumption and production, and the vision is "With the Nordic Ecolabel as a driving force make the Nordic countries a role model for a sustainable lifestyle".

The Nordic Ecolabel is a voluntary, third party certified labeling scheme that evaluates a product's or service's impact on the environment throughout the whole product's life-cycle. The label guarantees among other things that climate requirements are taken into account, and that CO2 emissions are minimized. By buying Nordic Swan Ecolabeled products and services consumers can contribute to a more sustainable environment. The label has been extremely successful and is very well known, with over 20,000 products in total so far labeled in the Nordic countries. 91\% of Nordic region consumers recognize the Nordic Swan Ecolabel.

\subsubsection{Objectives}

The Nordic Swan Ecolabel's mission is to promote sustainable consumption. By choosing products and services that are Nordic Swan Ecolabeled, consumers can actively contribute to the goal - achieving a more sustainable society and more sustainable lifestyles. Through the label, manufacturers are encouraged to develop environmentally sound products and services, and to achieve the goal of sustainable production. The Nordic Swan Ecolabel has a life-cycle perspective. Important environmental issues that are considered in the development of the label include: 
- Energy usage.

- Climate aspects.

- Water usage.

- Source of raw materials.

- Use of chemicals.

- Hazardous effluents.

- Packaging.

- Waste.

\subsubsection{Activities}

\section{Marketing and communication initiatives}

Marketing and communication is one of the core focus areas for the Nordic Ecolabel activities. Each Nordic country conducts a host of different activities to stimulate companies to apply for a Nordic Swan Ecolabel license, and to encourage the public to choose labeled products. These activities include local homepages as well as a Nordic Ecolabeling homepage (www.nordic-ecolabel.org), advertising, campaigns, seminars, webinars, podcasts, events, newsletters and an active presence in social media.

Lately the focus has been on using social media. In Sweden, especially Twitter and Linkedin are used, also because these channels have a good potential to reach politicians in addition to consumers. Denmark, Norway and Finland are strong in using especially Facebook. Facebook is especially efficient in reaching women between 40-60 years old that make active decisions on procuring eco-labeled products.

An example of a recent communication campaign (2015 and 2016) in Sweden, which was well received has been the "Save the world a little bit every day" campaign. The campaign message was that small daily choices and deeds matter. The campaign communication included outdoor ads in the subway, buses and trains (by means of ClearChannel and JC Decaux and GetOnBoard) and social media. The campaign included promotion of Nordic Swan Ecolabeled products as well as the Swan concept itself.

\section{Sustainable procurement network}

Driving up demand for labeled goods and services is vital to achieve a sustainable society. This is the purpose behind the Sustainable Procurement Network. Every company that wants to contribute to a sustainable society through their procurement is welcome to join the network. One aim is for labeled goods and services to be prioritized and to become a natural part of all procurement processes. 
Joint activities that provide inspiration and tips on how companies can make their operations more sustainable currently include seminars, breakfast meetings, webinars, podcasting, networking parties, and much more. The eco-label organization also passes on good advice and good practices of companies to others.

\section{Licensing}

The Nordic Swan Ecolabel is available in over 60 product areas, which cover both goods and services. A company can apply for a Nordic Swan Ecolabel within any of these product areas. When granted a license, the company may then use the Nordic Swan Ecolabel on all its marketing for all its products or services that are labeled. The national offices in five Nordic countries manage license applications and grant licenses.

The license applies for as long as the criteria for the product are valid. The criteria are revised and new product areas added on an ongoing basis. All the criteria documents along with instructions on how to apply are presented at www.nordic-ecolabel.org. Regular follow-up inspections are conducted in order to ensure that companies with a Nordic Swan Ecolabel license meet the requirements.

Development of licensing criteria is done through an extensive process, which includes pre-studies, research, public referrals and country approval by local Nordic Ecolabelling Boards. These boards are responsible for each country's stance on issues concerning criteria and new product groups. It is then up to the joint Nordic Ecolabelling Board to decide, which product groups and criteria will apply across the Nordic region.

In addition to setting requirements for environment, climate, health and performance, the Nordic Swan Ecolabel criteria also include social requirements concerning acceptable ethical conduct regarding child labor, forced labor, health and safety, freedom of association and the right to collective bargaining, discrimination, discipline, working hours and pay. All the criteria require, at minimum, compliance with national laws and regulations. 


\subsubsection{Success factors}

Critical for the success of the concept is honesty, trustworthiness (credibility), result-orientation and transparency. The Swan label has been able to maintain a consistently good reputation and trustworthiness. To be trustworthy means non-corruptibility, good controls at licensing and follow-up after licensing.

\subsubsection{Key Results and Achievements}

\section{Novelty}

The Nordic Swan Ecolabel has initially been fairly unique in that it addresses the entire lifecycle of the service or product and covers not only environmental factors but also social aspects. Today there are also other labels that have this approach. It is not a purely sectoral label, but can apply to many types of products or services.

\section{Sustainability Impacts}

At the end of 2014 there were 1869 issued licenses. There are over 20,000 labeled products in the Nordic countries. World-leading companies have Nordic Ecolabelled products, for example Procter \& Gamble, Samsung, Sharp, Fujitsu, Scandic Hotels, and SCA.

The success of all communication and campaign actions throughout the years is indicated by the high recognition figures that the Nordic Swan Ecolabel enjoys year after year. In the latest market survey (January 2015), 91\% of Nordic region consumers recognized the Nordic Swan Ecolabel. In Sweden the number was even higher at 96\%. Consumers associate the Nordic Swan Ecolabel logo with trust, see it as an official label and say they like the work that is being done. Consumers understand that the label represents a good choice for the environment. The label has raised the awareness of the importance of consumer choices and is an efficient way of highlighting products that can be trusted to produce limited environmental and other negative impacts.

Of the recent communication campaigns, the 2015 "Save the world a little bit every day" campaign generated 750 million contacts and received a very strong positive response from consumers. $80 \%$ of young people between the ages 16 to 29 liked the campaign. The sales of Nordic Swan Ecolabeled products included in the campaign developed very well. For instance, a brand of Nordic Swan Ecolabeled shampoo that was featured in the campaign had a sales increase of $750 \%$ during the two-week period the campaign ran. 


\section{Challenges and potential for further development}

Social media campaigns are more effective today than road shows or personal contacts. Social media and media exposure in general is more efficient in reaching large numbers of consumers.

Important for the success of the label has been the cooperation throughout the value chain, which includes also retail stores that choose which products to include in their stores selection.

Coordinated Nordic campaigns could be a good way forward to spread the same message efficiently in several countries also in the future. 



\section{Sammanfattning}

De nordiska länderna arbetar aktivt på både nationella och internationella fora för att befrämja ekonomisk utveckling i enlighet med hållbar exploatering av naturresurser. Den här rapporten är den andra i TemaNord serien som presenterar ett antal nordiska initiativ och projekt för att konkret och aktivt befrämja hållbar konsumtion och produktion (SCP). Rapporten har som målsättning att beskriva och dela med sig framgångsrika nordiska erfarenheter och lärdomar.

Initiativen som presenteras i rapporten omfattar två särskilda teman, dvs. Hållbar Turism, inkluderande ekoturism samt Hållbar Konsumentinformation. Dessa identifierades tillsammans med Nordiska Ministerrådets Arbetsgrupp för hållbar konsumtion och produktion. Initiativen som presenteras valdes från ett brett utbud av nordiska projekt och har som mål att sprida lärdomar om effektiva, framgångsrika och hållbara sätt att befrämja SCP.

Initiativen är sammanställda och presenterade på ett sätt som underlättar en jämförelse av centrala resultat och kriterier för framgång, och kan hjälpa i spridning och replikering av goda SCP lösningar. Beskrivningarna av initiativen bygger på material som varit tillgänglig för konsulten, inkluderande dokumentation samt intervjuer med representanter för de respektive initiativen.

De tio initiativen inom temat Hållbar Turism omfattar olika projekt och program som har utformats för att vägleda människor mot mer hållbar turism, såväl som utveckling av hållbara turistdestinationer. Målgrupperna i de olika exemplen sträcker sig från vanliga turister till entusiastiska ekoturister samt turistoperatörer och utvecklare av destinationer. Temat Hållbar Konsumentinformation omfattar nio initiativ med fokus på lösningar, som kan underlätta konsumenternas tillgång till trovärdig och lättförståelig informaion om mera hållbara konsumtionsval. Exemplen omfattar bland annat miljömärken, informationskampanjer, webbsidor, mobilapp och samarbetsmodeller för myndigheter.

I linje med det övergripande målet för det här nordiska projektet Nordic Best practices, har initiativen även lagts in i den så kallade SCP Clearinghouse ${ }^{4}$ webbportalen, som fungerar som informationsplattform för

${ }^{4} \mathrm{http}: / /$ www.scpclearinghouse.org/ 
UNEP: s 10 års ramprogram för hållbar produktion och konsumtion. Ramprogrammet för FN:s miljöprogram UNEP gällande hållbar produktion och konsumtion (10YFP) är ett konkret resultat av Rio +20 och dess syfte är att stärka det internationella samarbetet för att accelerera en övergång till mer hållbar konsumtion och produktion i både utveckladeoch utvecklingsländer. SCP Clearinghouse är ett webbaserat verktyg för informationsutbyte som kan användas av olika aktörer för att få inspiration om olika sätt att befrämja mer hållbar konsumtion och produktion överallt i världen. SCP Clearinghouse ger också tillgång till ytterligare material och länkar till mer omfattande information om de nitton initiativ som presenteras här i rapporten. 


\section{SCP Themes and Sectors in UNEP's SCP Clearinghouse ${ }^{5}$}

- 10YFP Sustainable Lifestyles \& Education Programme

- SCP Knowledge Base

- Sustainable Urban Development and Cities

- SCP, Poverty reduction and Sustainable Livelihoods

- Sustainable Public Procurement

- Agri-food

- Chemicals

- Fair trade

- Health and Social Services

- Management and Human Resources

- Mining and Metals

- Tourism

- Waste

- SPP and Ecolabelling

- Sustainable Food Systems

- SCP Policy and Economic Frameworks

- Lifecycle Perspective

- Sustainable Rural development

- Sustainable Lifestyles and Consumption

- Sustainable Production and Value Chains

- Awareness-raising and Education for SCP

- Buildings and Construction

- Energy

- Finance and Insurance

- Media, Advertizing and Marketing

- Manufacturing

- Retailing

- Transports and mobility

- Water 



\section{SCP Communities in UNEP's SCP Clearinghouse $^{6}$}

- Sustainable Buildings and Construction

- Energy Efficiency

- Sustainable Lifestyles and Education

- Consumer Information

- Scientific Knowledge

- SCP National Policy frameworks/strategies

- Sustainable Food Systems

- Sustainable Public Procurement

- Sustainable and Safer Production

- Sustainable Tourism

- SCP Africa

- SCP Asia and the Pacific

- SCP Europe

- SCP Latin America and the Caribbean

- SCP Mediterranean

- $\quad$ SCP West Asia 



\section{Types of Initiative in UNEP's SCP Clearinghouse $^{7}$}

- Policy frameworks and processes

- E.g. International agreements, bilateral agreements, strategic planning, action plans, enhancement of existing policies, new institutions/entities.

- Regulatory instruments and legal reforms

- E.g. Laws, standards, enforcement measures.

- Economic and financial instruments

- E.g. Taxes and tax incentives, grants, preferential loans.

- Public and private investments

- E.g. investment programmes, procurement programmes.

- Capacity-building and technology transfer

- E.g. Advisory services, trainings, best practices sharing, guidelines, toolkits, manuals.

- Analysis and assessment

- E.g. Policy opportunity and impact assessments, collection of SCP case studies, data collection, SCP indicators, assessment methodologies (e.g. lifecycle assessment).

- Research and development

- E.g. Research programmes, technology development.

- Partnerships and voluntary agreements

- E.g. Multi-stakeholder partnerships, sectoral partnerships, codes of conduct, CRS initiatives.

- Production and value-chain management

- E.g. Integrated product policy, product/service design, production processes.

- Information, awareness-raising, education

- E.g. Consumer information, eco-labels and certification, formal/ non formal education, public/media campaigns.

${ }^{7}$ http://www.scpclearinghouse.org/ 
